National Water Quality Assessment Program

Transport of Anthropogenic and Natural Contaminants (TANC) to Public-Supply Wells

Simulations of Ground-Water Flow, Transport, Age, and Particle Tracking near York, Nebraska, for a Study of Transport of Anthropogenic and Natural Contaminants (TANC) to Public-Supply Wells

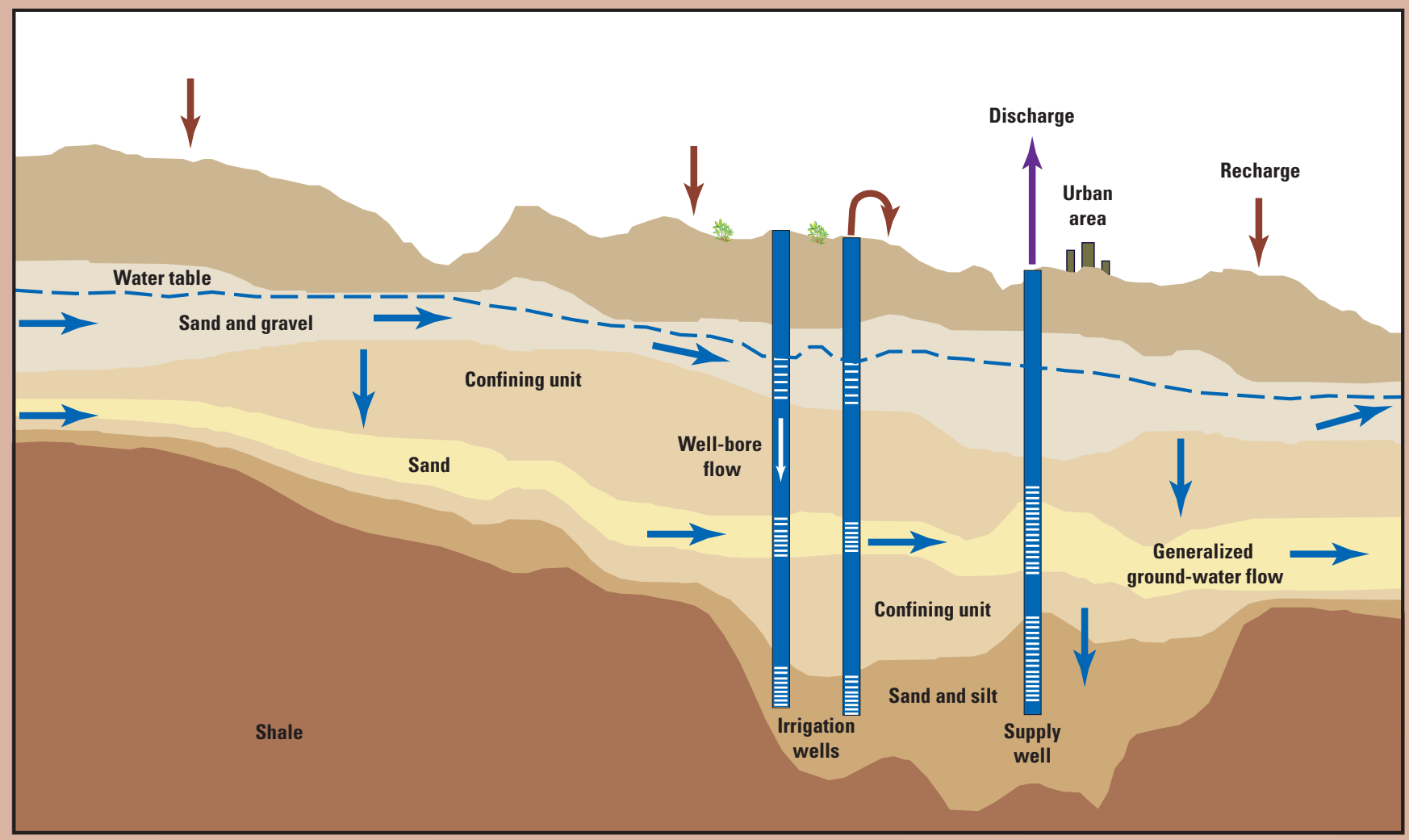

Scientific Investigations Report 2007-5068 


\section{Simulations of Ground-Water Flow, Transport, Age, and Particle Tracking near York, Nebraska, for a Study of Transport of Anthropogenic and Natural Contaminants (TANC) to Public-Supply Wells}

By Brian R. Clark, Matthew K. Landon, Leon J. Kauffman, and George Z. Hornberger

Scientific Investigations Report 2007-5068 


\section{U.S. Department of the Interior DIRK KEMPTHORNE, Secretary}

\section{U.S. Geological Survey \\ Mark D. Myers, Director}

\section{U.S. Geological Survey, Reston, Virginia: 2008}

For product and ordering information:

World Wide Web: http://www.usgs.gov/pubprod

Telephone: 1-888-ASK-USGS

For more information on the USGS--the Federal source for science about the Earth, its natural and living resources, natural hazards, and the environment:

World Wide Web: http://www.usgs.gov

Telephone: 1-888-ASK-USGS

Any use of trade, product, or firm names is for descriptive purposes only and does not imply endorsement by the U.S. Government.

Although this report is in the public domain, permission must be secured from the individual copyright owners to reproduce any copyrighted materials contained within this report.

Suggested citation:

Clark, B.R., Landon, M.K., Kauffman, L.J., and Hornberger, G.Z., 2008, Simulations of ground-water flow, transport, age, and particle tracking near York, Nebraska, for a study of transport of anthropogenic and natural contaminants (TANC) to public supply wells: U.S. Geological Survey Scientific Investigations Report 2007-5068, 48 p. 


\section{FOREWORD}

The U.S. Geological Survey (USGS) is committed to providing the Nation with credible scientific information that helps to enhance and protect the overall quality of life and that facilitates effective management of water, biological, energy, and mineral resources (http://www.usgs.gov//). Information on the Nation's water resources is critical to ensuring long-term availability of water that is safe for drinking and recreation and is suitable for industry, irrigation, and fish and wildlife. Population growth and increasing demands for water make the availability of that water, now measured in terms of quantity and quality, even more essential to the long-term sustainability of our communities and ecosystems.

The USGS implemented the National Water-Quality Assessment (NAWQA) Program in 1991 to support national, regional, State, and local information needs and decisions related to water-quality management and policy (http://water.usgs.gov/ nawqa). The NAWOA Program is designed to answer: What is the condition of our Nation's streams and ground water? How are conditions changing over time? How do natural features and human activities affect the quality of streams and ground water, and where are those effects most pronounced? By combining information on water chemistry, physical characteristics, stream habitat, and aquatic life, the NAWQA Program aims to provide science-based insights for current and emerging water issues and priorities. From 1991-2001, the NAWQA Program completed interdisciplinary assessments and established a baseline understanding of water-quality conditions in 51 of the Nation's river basins and aquifers, referred to as Study Units (http://water.usgs.gov/nawqa/studyu.html).

Multiple national and regional assessments are ongoing in the second decade (2001-2012) of the NAWQA Program as 42 of the 51 Study Units are reassessed. These assessments extend the findings in the Study Units by determining status and trends at sites that have been consistently monitored for more than a decade, and filling critical gaps in characterizing the quality of surface water and ground water. For example, increased emphasis has been placed on assessing the quality of source water and finished water associated with many of the Nation's largest community water systems. During the second decade, NAWQA is addressing five national priority topics that build an understanding of how natural features and human activities affect water quality, and establish links between sources of contaminants, the transport of those contaminants through the hydrologic system, and the potential effects of contaminants on humans and aquatic ecosystems. Included are topics on the fate of agricultural chemicals, effects of urbanization on stream ecosystems, bioaccumulation of mercury in stream ecosystems, effects of nutrient enrichment on aquatic ecosystems, and transport of contaminants to public-supply wells. These topical studies are conducted in those Study Units most affected by these issues; they comprise a set of multiStudy-Unit designs for systematic national assessment. In addition, national syntheses of information on pesticides, volatile organic compounds (VOCs), nutrients, selected trace elements, and aquatic ecology are continuing.

The USGS aims to disseminate credible, timely, and relevant science information to address practical and effective waterresource management and strategies that protect and restore water quality. We hope this NAWQA publication will provide you with insights and information to meet your needs, and will foster increased citizen awareness and involvement in the protection and restoration of our Nation's waters.

The USGS recognizes that a national assessment by a single program cannot address all water-resource issues of interest. External coordination at all levels is critical for cost-effective management, regulation, and conservation of our Nation's water resources. The NAWQA Program, therefore, depends on advice and information from other agencies-Federal, State, regional, interstate, Tribal, and local — as well as nongovernmental organizations, industry, academia, and other stakeholder groups. Your assistance and suggestions are greatly appreciated.

Robert M. Hirsch

Associate Director for Water 



\section{Contents}

Abstract

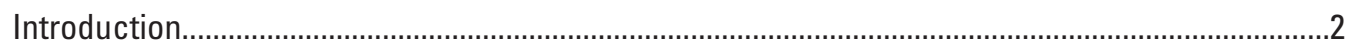

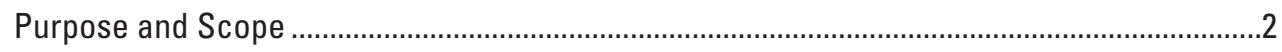

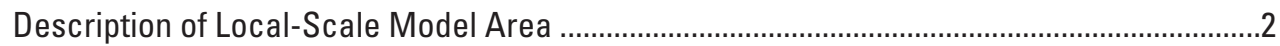

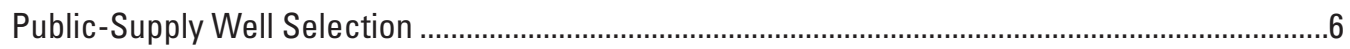

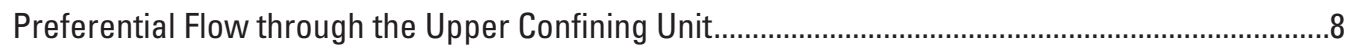

Methods for Simulation of Ground-Water Flow and Age........................................................12

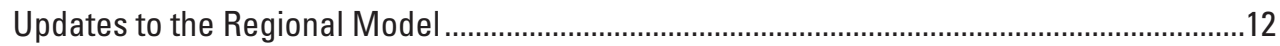

Local-Scale Model Geometry and Discretization ...........................................................12

Boundary Conditions, Model Stresses, and Initial Conditions ..............................................13

Model Hydraulic Parameters.........................................................................................18

Model Parameters for Simulating Ground-Water Age and CFC-11 Concentrations ...............20

Alternative Model Construction ...........................................................................................21

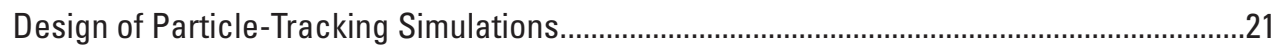

Flow and Transport Model Uncertainties and Limitations ...........................................................22

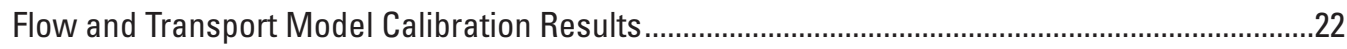

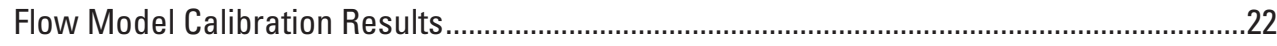

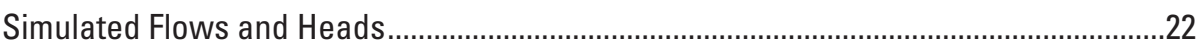

Simulated Water Budget ...........................................................................................26

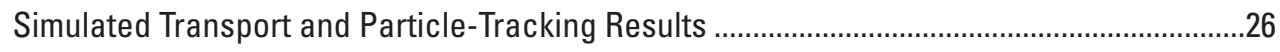

Contributing Recharge Area Summary .......................................................................32

Comparison of Simulated Transport and Particle Tracking Age Distribution ..................32

Long-Term Concentrations of Nitrate in the Study Public-Supply Well ............................36

Implications of Well-Bore Leakage on Ground-Water Quality .......................................................38

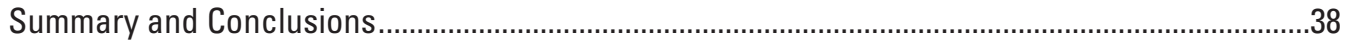

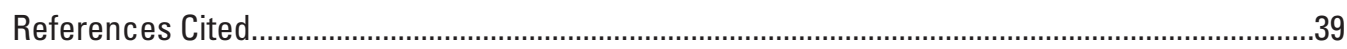

Appendix 1. Computation of MODPATH Particle Traveltimes Through Well Bores..........................43

Appendix 2. Digital Three-Dimensional Animations of CFC-11 Transport Simulations ..................47

\section{Figures}

1. Map showing High Plains Ground-Water Transport of Anthropogenic and Natural Contaminants local-scale and regional-scale model areas...............................................

2. Diagram showing generalized west to east hydrogeologic section of the local-scale model area showing potential paths of ground-water flow through well bores ..............4

3. Hydrographs from wells with largest portion of well screen in the unconfined aquifer .....6

4. Graph showing cumulative number of wells installed by year in the regional-scale

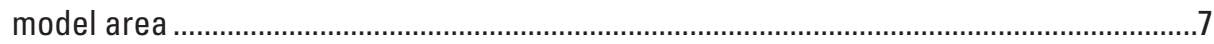

5. Graph showing precipitation (by stress period) in the local-scale model area, at

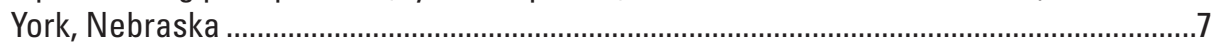

6. Graph showing input withdrawal rate by stress period calculated by linear regression ...8

7. Map showing locations of wells and well nests within the local-scale model boundary...9 
8. Graph showing change in hydraulic heads in wells screened primarily in the

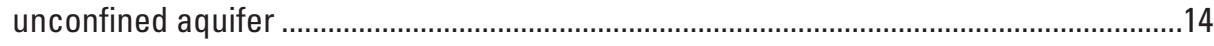

9. Map showing four recharge zones in the local-scale model ...............................................15

10. Graphs showing simulated recharge for the four recharge zones in the local-scale

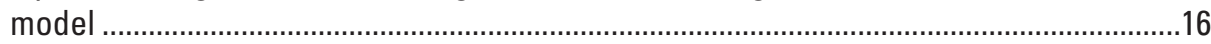

11. Linear regression of average measured seasonal irrigation application and JuneAugust precipitation at York, Nebraska ........................................................................17

12. Graphs of simulated and observed hydrographs............................................................2

13. Map showing contours of simulated hydraulic heads of the unconfined and upper confined aquifers for the stress period ending in the spring of 2004 and summer of 2004

14. Graph showing simulated and observed flow measurements in the study public-supply well

15. Map showing wells with leakage from the unconfined aquifer to one or both confined aquifers, wells with no leakage to either confined aquifer, and abandoned wells and test holes.

16. Map showing wells with average percentage of total desired withdrawal allowed by drawdown constraints in multi-node wells.

17. Graph showing components of the simulated water budget that have inflow or outflow exceeding 10,000 cubic meters per day.

18. Graph showing simulated leakage through well bores and leakage through the upper confining unit

19. Graph showing comparison of simulated and interpreted age and measured CFC-11 concentrations for six selected wells

20. Map showing simulated CFC-11 distribution in upper confined aquifer during fall of 2003 (stress period 119)

21. Map showing simulated contributing recharge area to the study public-supply well ......34

22. Graph showing age distribution comparisons of the steady-state model using MODPATH, steady-state model using Ground-Water Transport, and calibrated model using Ground-Water Transport for the study public-supply well

23. Graph showing age distribution simulated by steady-state model using MODPATH by percent of water entering the study public-supply well through well bores, the upper confining unit, and a composite of both....

24. Graph showing simulated long-term nitrate-N concentration at the study public-supply well

\section{Tables}

1. Final calibrated values of hydrogeologic properties of the local-scale model

2. Well construction information for monitoring wells installed for the local-scale TANC study near York, Nebraska

3. Residual statistics for model calibration..........................................................................19

4. Ground-water budget comparison between predevelopment and summer, 2004.............26

5. Comparison of simulated and interpreted age simulations for water from wells screened in the unconfined aquifer ..................................................................................26

6. Comparison of simulated and measured CFC-11 concentrations for water from wells screened in the upper confined aquifer

7. The study public-supply well information and contributing recharge area summary statistics. 


\section{Conversion Factors and Datums}

\begin{tabular}{lcl}
\hline \multicolumn{1}{c}{ Multiply } & By & \multicolumn{1}{c}{ To obtain } \\
\hline foot $(\mathrm{ft})$ & Length & \\
mile $(\mathrm{mi})$ & 0.3048 & meter $(\mathrm{m})$ \\
& 1.609 & kilometer $(\mathrm{km})$ \\
\hline foot per year $(\mathrm{ft} / \mathrm{yr})$ & Flow rate & \\
gallon per minute $(\mathrm{gal} / \mathrm{m})$ & 0.3048 & meter per vear $(\mathrm{m} / \mathrm{yr})$ \\
million gllons per day $(\mathrm{Mgal} / \mathrm{d})$ & 0.6308 & liter per second $(\mathrm{L} / \mathrm{s})$ \\
\hline
\end{tabular}

Temperature in degrees Celsius $\left({ }^{\circ} \mathrm{C}\right)$ may be converted to degrees Fahrenheit $\left({ }^{\circ} \mathrm{F}\right)$ as follows:

${ }^{\circ} \mathrm{F}=\left(1.8 \mathrm{x}^{\circ} \mathrm{C}\right)+32$

Vertical coordinate information is referenced to the National Geodetic Vertical Datum of 1929 (NGVD of 1929).

Horizontal coordinate information is referenced to the North American Datum of 1983 (NAD of 1983). 


\title{
Simulations of Ground-Water Flow, Transport, Age, and Particle Tracking near York, nebraska, for a Study of Transport of Anthropogenic and Natural Contaminants (TANC) to Public-Supply Wells
}

\author{
By Brian R. Clark, Matthew K. Landon, Leon J. Kauffman, and George Z. Hornberger
}

\section{Abstract}

Contamination of public-supply wells has resulted in public-health threats and negative economic effects for communities that must treat contaminated water or find alternative water supplies. To investigate factors controlling vulnerability of public-supply wells to anthropogenic and natural contaminants using consistent and systematic data collected in a variety of principal aquifer settings in the United States, a study of Transport of Anthropogenic and Natural Contaminants to public-supply wells was begun in 2001 as part of the U.S. Geological Survey National Water-Quality Assessment Program.

The area simulated by the ground-water flow model described in this report was selected for a study of processes influencing contaminant distribution and transport along the direction of ground-water flow towards a public-supply well in southeastern York, Nebraska. Ground-water flow is simulated for a 60-year period from September 1, 1944, to August 31, 2004. Steady-state conditions are simulated prior to September 1,1944 , and represent conditions prior to use of ground water for irrigation.

Irrigation, municipal, and industrial wells were simulated using the Multi-Node Well package of the modular three-dimensional ground-water flow model code, MODFLOW-2000, which allows simulation of flow and solutes through wells that are simulated in multiple nodes or layers. Ground-water flow, age, and transport of selected tracers were simulated using the Ground-Water Transport process of MODFLOW-2000. Simulated ground-water age was compared to interpreted groundwater age in six monitoring wells in the unconfined aquifer. The tracer chlorofluorocarbon-11 was simulated directly using Ground-Water Transport for comparison with concentrations measured in six monitoring wells and one public supply well screened in the upper confined aquifer.

Three alternative model simulations indicate that simulation results are highly sensitive to the distribution of multilayer well bores where leakage can occur and that the calibrated model resulted in smaller differences than the alternative models between simulated and interpreted ages and measured tracer concentrations in most, but not all, wells. Results of the first alternative model indicate that the distribution of young water in the upper confined aquifer is substantially different when well-bore leakage at known abandoned wells and test holes is removed from the model. In the second alternative model, simulated age near the bottom of the unconfined aquifer was younger than interpreted ages and simulated chlorofluorocarbon-11 concentrations in the upper confined aquifer were zero in five out of six wells because the conventional Well Package fails to account for flow between model layers though well bores. The third alternative model produced differences between simulated and interpreted ground-water ages and measured chlorofluorocarbon-11 concentrations that were comparable to the calibrated model. However, simulated hydraulic heads deviated from measured hydraulic heads by a greater amount than for the calibrated model. Even so, because the third alternative model simulates steady-state flow, additional analysis was possible using steady-state particle tracking to assess the contributing recharge area to a public supply well selected for analysis of factors contributing to well vulnerability.

Results from particle-tracking software (MODPATH) using the third alternative model indicates that the contributing recharge area of the study public-supply well is a composite of elongated, seemingly isolated areas associated with wells that are screened in multiple aquifers. The simulated age distribution of particles at the study public-supply well indicates that all water younger than 58 years travels through well bores of wells screened in multiple aquifers. The age distribution from the steady-state model using MODPATH estimates the youngest 7 percent of the water to have a flow-weighted mean age of 16 years. In comparison, interpretations of age tracer and stable isotope data indicate water samples from the study public-supply well are a mixture of 7 to 14 percent water with a mean age of 14 years or less mixed with 86 to 93 percent old, upper confined aquifer water. 
Long-term projections of nitrate-nitrogen concentrations and the effects of denitrification were made using simulated ages from the steady-state model with MODPATH, estimates of historical and projected nitrate-nitrogen concentrations in recharge, and estimated denitrification rates. The calculated concentration of nitrate-nitrogen of 0.19 milligrams per liter for 2003 of the projection is similar to measured values of nitrate-nitrogen at the study public-supply well, which range from 0.17 to 0.20 milligrams per liter. The projections indicate that nitrate-nitrogen concentrations will remain near steadystate values for the duration of the 100 -year projection period as long as denitrification rates remain constant and steadystate flow conditions occur. While simplistic, the conceptual calculations indicate the importance of denitrification as a mechanism influencing nitrate-nitrogen concentrations in the study area. The peak value of decayed nitrate-N appears to lag behind the input concentration in recharge by approximately 30 years.

Young, potentially contaminated water in the unconfined aquifer can move downward into the confined aquifers of the ground-water system where public-supply wells are screened. Water chemistry results and results of Ground-Water Transport age and tracer simulations indicate that wells screened through multiple aquifers can introduce flow through the well bores, thus providing a "short circuit" from the unconfined aquifer to the upper confined aquifer. Simulations indicate that chlorofluorocarbon-11 concentrations in the upper confined aquifer originate at wells screened through multiple aquifers and are drawn toward other pumping wells. This mechanism for movement of younger water through the well bores of wells screened through multiple aquifers is thought to be the primary process affecting the presence and distribution of contaminants in the confined aquifers and is in agreement with independent geochemical data.

\section{Introduction}

Contamination of public-supply wells (PSW) has resulted in public-health threats and negative economic effects for communities that must treat contaminated water or find alternative water supplies. The concerns about contamination of PSW have led to widespread interest in understanding the vulnerability of PSW to contamination. The definition of vulnerability, as used in this report, is taken from the National Research Council (1993), "the tendency or likelihood for contamination to reach a specified position in the ground-water system after introduction at some location above the uppermost aquifer." To investigate factors controlling vulnerability of PSW to anthropogenic and natural contaminants using consistent and systematic data collected in a variety of principal aquifer settings in the United States, a study of Transport of Anthropogenic and Natural Contaminants (TANC) to PSW was begun in 2001 as part of the U.S. Geological Survey (USGS) National WaterQuality Assessment (NAWQA) Program (Eberts and others,
2005). A High Plains Regional Ground-Water (HPGW) TANC study was done near York, in southeastern Nebraska (fig. 1), within the HPGW study unit of the NAWQA Program (Dennehy, 2000).

The hydrogeology and possible sources of contamination at York are typical of conditions that occur in many communities across the Midwest or other predominantly rural areas of the Nation near irrigated agriculture. In these rural agricultural areas, the movement of contaminants through aquifers is enhanced because of increased ground-water flow velocities caused by intensive ground-water pumping for irrigation and increased recharge because of irrigation return flows. Moreover, the practice of screening wells across multiple aquifers can contribute to faster vertical movement of contaminants to depth than would naturally occur because of penetration of confining units by well bores and possible inter-aquifer mixing. This study was designed to use model simulations conducted to improve understanding of the transport processes influencing movement of contaminants to PSW in the HPGW TANC study area within the HPGW study unit. These simulations included investigation of flow through well bores as a primary process affecting solute movement to PSW.

\section{Purpose and Scope}

The purpose of this report is to document the construction, calibration, and simulation results of local-scale groundwater flow and transport models used in the HPGW TANC study at York, Nebraska. Ground-water flow and solute transport were simulated using a local-scale model (approximately 100 square kilometers), which was nested within a regionalscale model (hundreds of square kilometers) (Landon and Turco, 2007). Subsequently, solute movement was simulated in a transport model subgrid within the local-scale model (fig. 1). This report also describes the approaches used to modify the previously developed regional-scale model (Landon and Turco, 2007). In addition, a basic description of simulations of ground-water age and selected age tracer concentrations and the simulation results are included in the report. The modeling results described in this report expand on work presented by Landon and others, 2007 for factors influencing transport of selected anthropogenic and natural contaminants to supply wells for the HPGW TANC study area near York, Nebraska. This report is intended to serve as a foundation for synthesis analyses comparing results between this HPGW TANC model area and others in California, Connecticut, and Florida (U.S. Geological Survey, 2007).

\section{Description of Local-Scale Model Area}

The local-scale model area is a rectangular area of 108.2 $\mathrm{km}^{2}$ and was selected for a study of processes influencing contaminant distribution and transport between recharge areas and a PSW in southeastern York, Nebraska (fig. 1). The local-scale model is nested within a regional-scale model of 


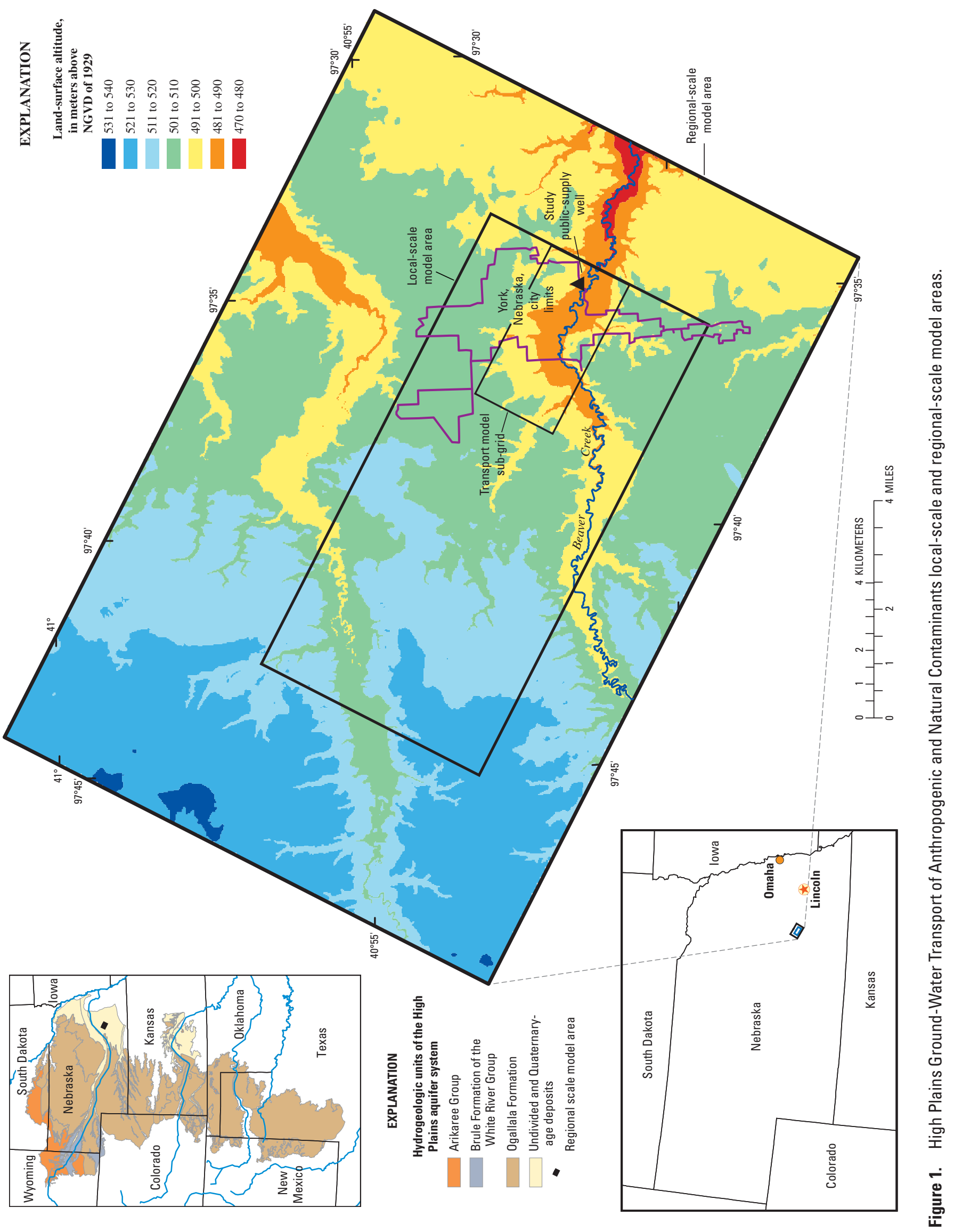


$388.5 \mathrm{~km}^{2}$ (Landon and Turco, 2007). Mean annual precipitation near York is $71.1 \mathrm{~cm} / \mathrm{yr}$ (High Plains Climate Center, 2003). Irrigated agriculture is the primary land use in both the regional-scale (approximately 62 percent of the total area) and local-scale (approximately 54 percent of the total area) model areas with corn and soybeans the primary crops. Ground water is the sole source of water for irrigation, domestic, public supply, and commercial supply in both the regional-scale and local-scale model areas (Landon and Turco, 2007). The HPGW TANC study area is underlain by Quaternary-age alluvial deposits that constitute the High Plains aquifer system in eastern Nebraska and Kansas.

The hydrogeologic system that underlies the regionalscale and local-scale model areas consists of several aquifers (fig. 2). The following descriptions and thicknesses were determined from driller and geophysical log information. The thicknesses are averages of interpolated surfaces based on log information. An unconfined aquifer near the surface is composed of mostly sand and gravel and has an average thickness of $27 \mathrm{~m}$. A clayey silt till confining unit (upper confining unit), with an average thickness of $22 \mathrm{~m}$, separates the unconfined aquifer from the underlying upper confined aquifer (average thickness of $10 \mathrm{~m}$ ), the primary source of ground water for public supply (table 1). Below the upper confined aquifer are heterogeneous deposits composed of mostly clayey silt mixed with thin sand lenses. These deposits primarily serve as a lower confining unit separating a lower confined aquifer, consisting primarily of thin sand lenses, from the two overlying aquifers. The lower confined aquifer is not present at all locations.

Well construction methods used in the area provide potential pathways for movement of contaminants. Many irrigation wells, and some commercial and PSW, are screened across unconfined and confined aquifers to maximize yields. Vertical hydraulic-head differences between the unconfined and confined aquifers are as much as $15 \mathrm{~m}$ during the summer irrigation season and $3 \mathrm{~m}$ during other seasons (Landon and others, 2007). The large downward head gradients make these multi-screened wells potential pathways for rapid movement of ground water across the confining units, allowing contaminants to reach the upper confined aquifer where most PSW are screened.

Hydraulic-head data collected since the 1950's indicate periods of withdrawals from and additions to aquifer storage. Long-term ground-water hydrographs (fig. 3) indicate spring ground-water hydraulic heads in the unconfined aquifer near York decreased about 2.2 to $4.7 \mathrm{~m}$ from 1957 to 1982 , increased about 4.6 to $5.2 \mathrm{~m}$ from 1982 to 1995 , were relatively stable from 1995 to 2001 , and declined 2 to $3 \mathrm{~m}$ from 2001 to 2004 (fig. 3). Spring ground-water hydraulic heads were used because they are least likely to be affected by localized drawdown caused by summertime irrigation withdrawals.

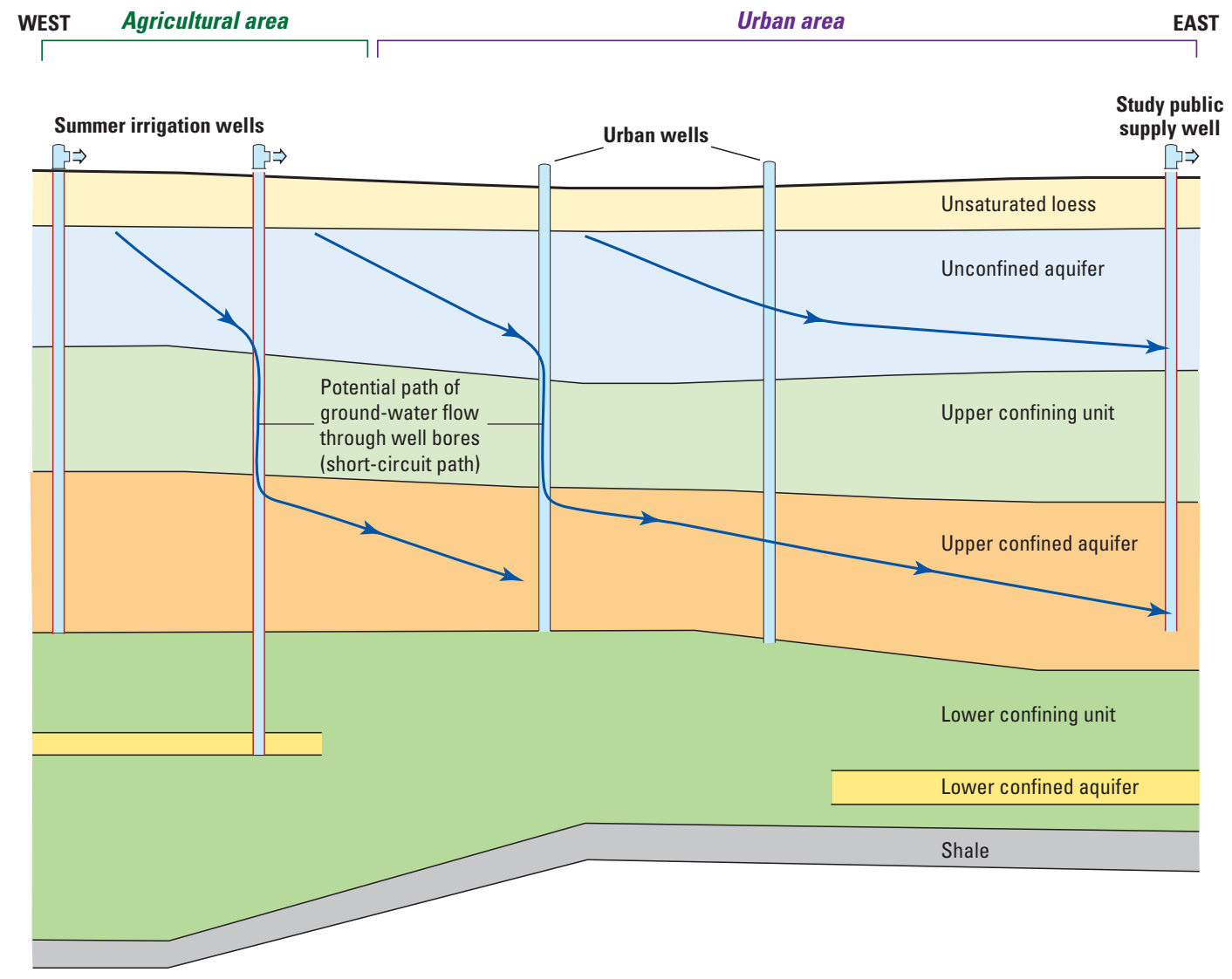

Figure 2. Generalized west to east hydrogeologic section of the local-scale model area showing potential paths of ground-water flow through well bores. 


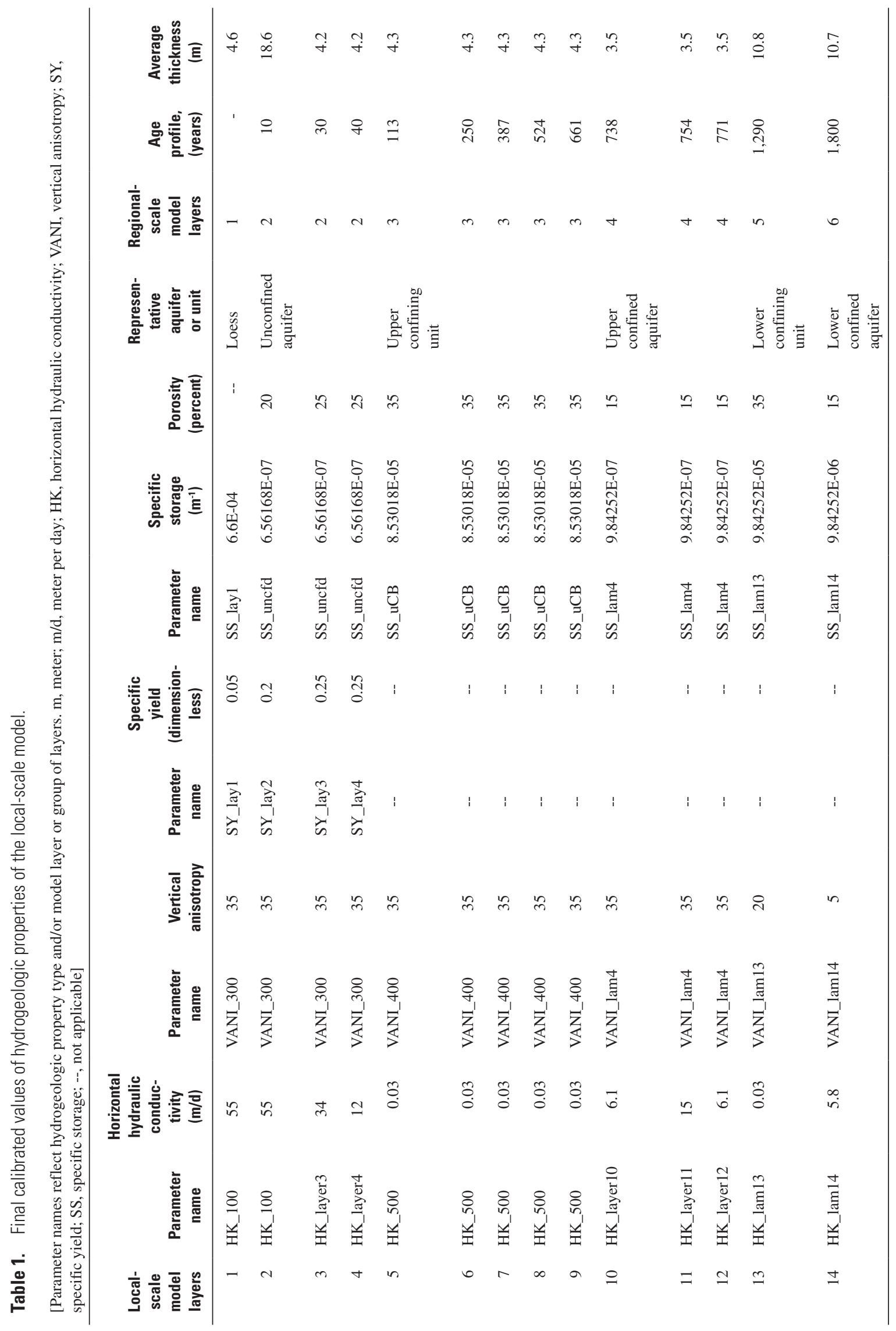




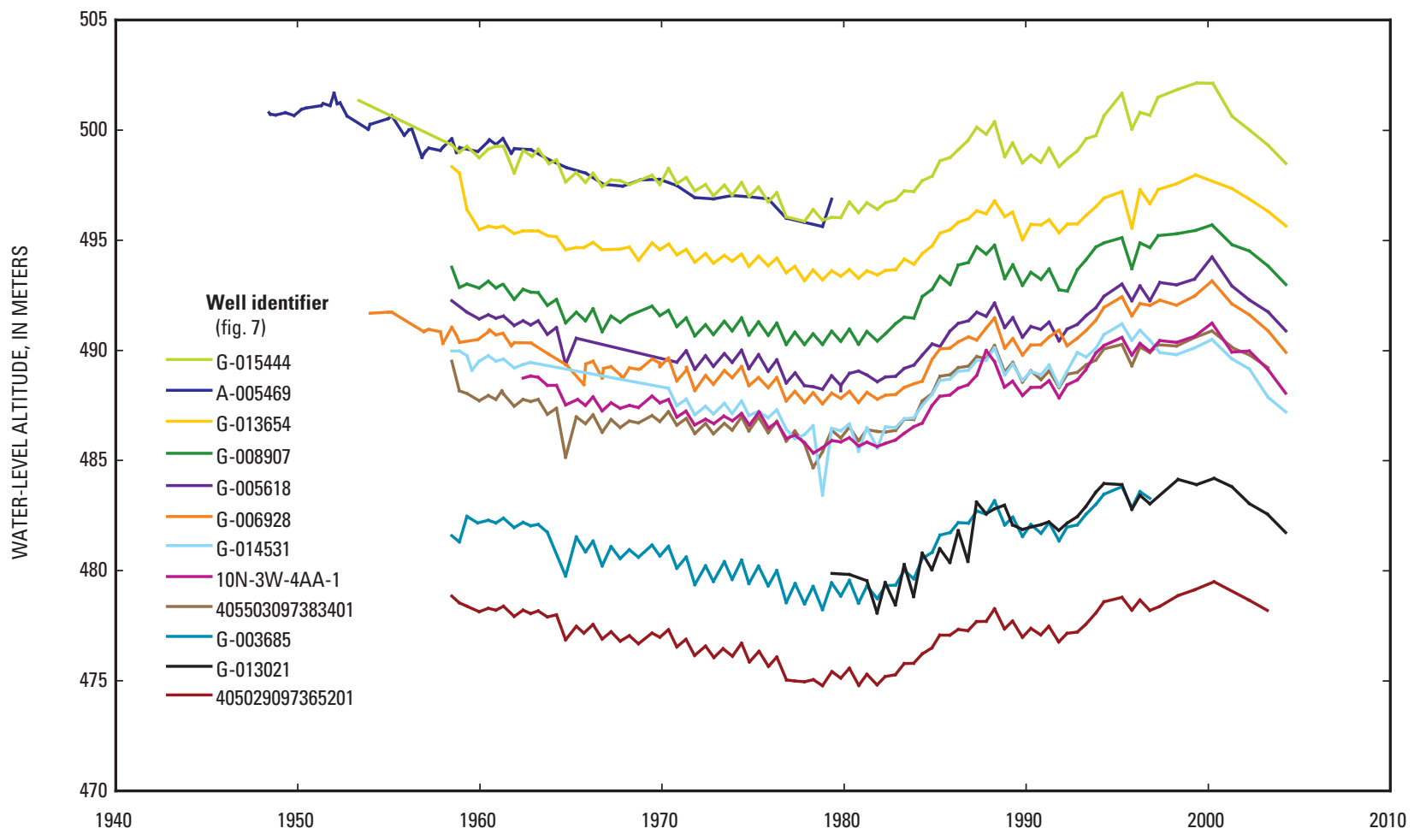

Figure 3. Hydrographs from wells with largest portion of well screen in the unconfined aquifer.

During 1955-1980, large increases in the installation rate of irrigation wells (Nebraska Department of Natural Resources, 2003) (fig. 4) and periods of low summer precipitation (High Plains Climate Center, 2003), particularly in the middle 1950s and mid 1970s to early 1980's (fig. 5), resulted in a period where outflows from the aquifer exceeded inflows to the aquifer and hydraulic heads declined. Thereafter, wetter climatic conditions during parts of the 1980s and early 1990s, along with gradual conversion from gravity to sprinkler irrigation and improved irrigation efficiency, probably contributed to the rising hydraulic heads during 1982-1995. By the end of this period, spring hydraulic heads generally were higher than those prior to 1960 (fig. 3), indicating a return to hydraulic heads that existed prior to extensive irrigation with ground water. During 1995-2001, spring hydraulic heads fluctuated by less than $1.2 \mathrm{~m}$, indicating an approximate 6 -year balance between aquifer inflows and outflows. Because ground-water withdrawals, primarily for irrigation, increased substantially between the 1950s and late 1990s (fig. 6), the similarity in hydraulic heads in the late 1990s and the 1950's implies that recharge, the primary ground-water inflow, has increased compared to pre-irrigation conditions. Increases in ground-water recharge from pre-development or pre-irrigation conditions to post-irrigation conditions have been identified in previous ground-water modeling studies across the High Plains (Luckey and others, 1986; Landon and Johnson, 2002).

The authors wish to thank land owners, public and private, who granted permission for wells to be installed on their property. We were greatly assisted in this study by personnel with the city of York, Nebraska, and the Upper Big Blue Natural Resources District.

\section{Public-Supply Well Selection}

The study PSW (fig. 7) was selected for the analysis of factors contributing to well vulnerability. The study PSW was selected based upon several factors: (1) the occurrence of constituents of concern in trace concentrations in the well, (2) land use in the apparent zone of contribution, which includes both urban and agricultural areas, (3) the relative importance of the well as a source of water for public supply, and (4) sufficient distance between the well and other major supply wells to reduce interference effects that could complicate interpretation of data and model results. Sampling of the study PSW and seven other York PSW for the NAWQA Source WaterQuality Assessment (SWQA) Program in October-December 2002, and subsequent sampling through April 2005, indicated that the study PSW had detections of trichloroethylene (TCE, 0.36-0.51 $\mu \mathrm{g} / \mathrm{L}$ ), tetrachloroethylene (PCE, 0.79-0.92 $\mu \mathrm{g} / \mathrm{L}$ ), and their degradation products, uranium concentrations below drinking-water standards ( $17 \mu \mathrm{g} / \mathrm{L})$, and moderate arsenic concentrations of about $6 \mu \mathrm{g} / \mathrm{L}$ (Landon and others, 2007). Nitrate concentrations in the study PSW historically have been low (less than 0.06 to 0.7 milligrams per liter), but reconnaissance sampling for dissolved gases in February 2003 indicated excess (above concentration in water in equilibrium air at the 


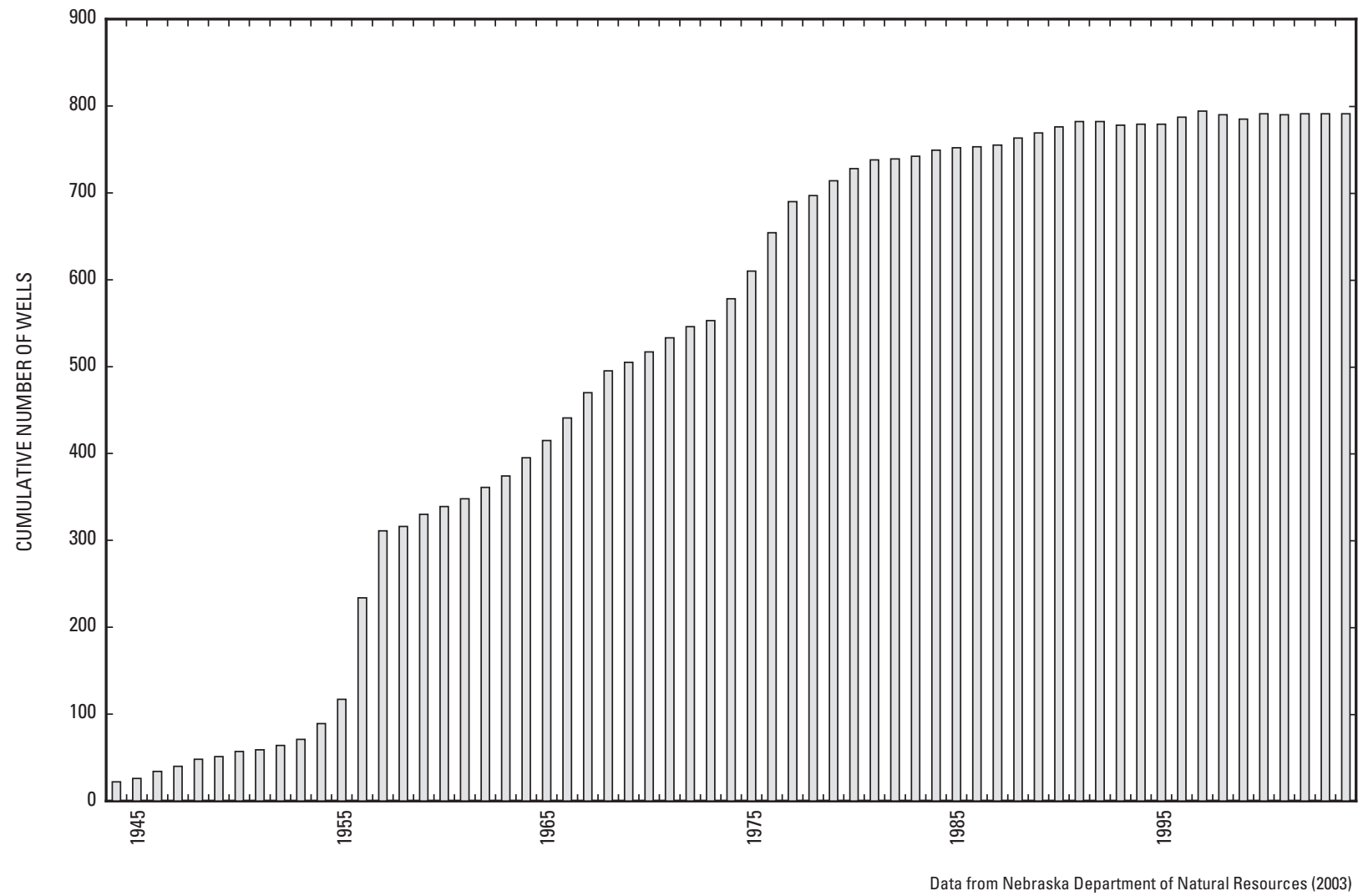

Figure 4. Cumulative number of wells installed by year in the regional-scale model area.

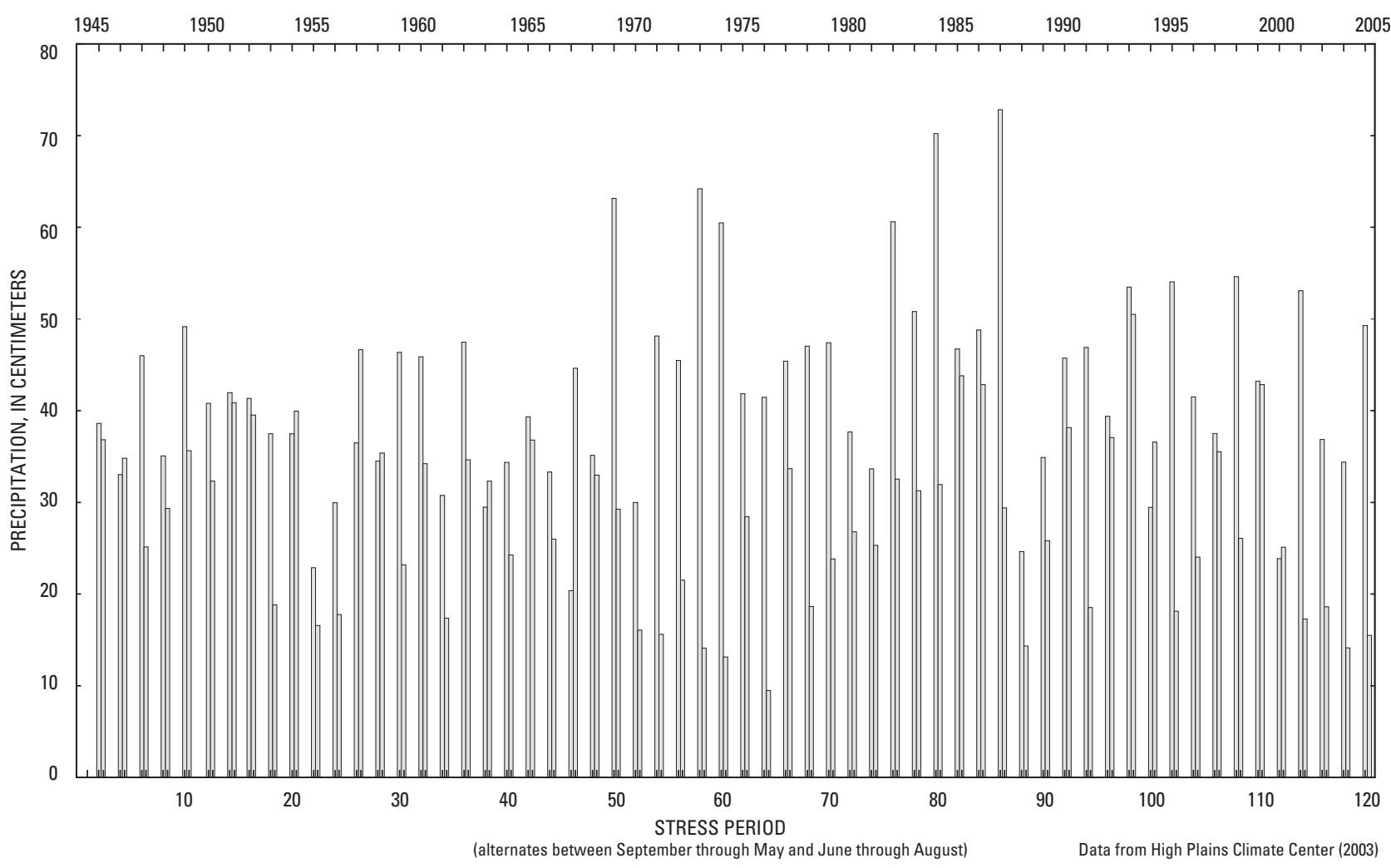

Figure 5. Precipitation (by stress period) in the local-scale model area, at York, Nebraska. Stress periods alternate between September through May and June through August. 


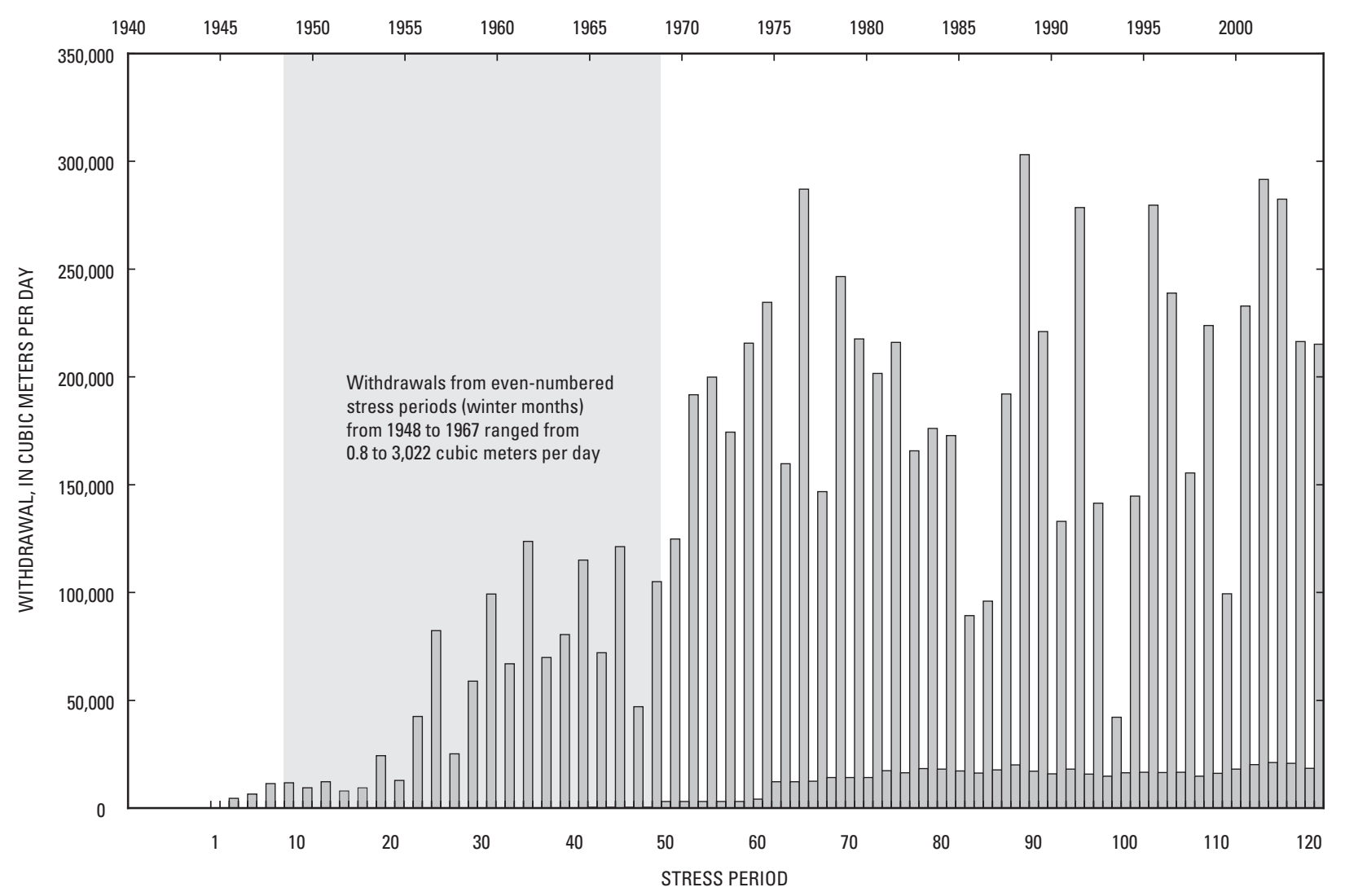

Figure 6. Input withdrawal rate by stress period calculated by linear regression.

estimated recharge temperature) nitrogen gas concentrations of $1-2 \mathrm{mg} / \mathrm{L}$, suggesting that denitrification was occurring and that some nitrate would reach the well if denitrification was not occurring. These reconnaissance results suggested that several anthropogenic and natural constituents of interest could be investigated at the study PSW. The location of the study PSW on the eastern or downgradient edge of York provided an opportunity to investigate the effects of both urban and agricultural land use in the area that contributes water to the study PSW. Most of the other seven wells sampled by the SWQA Program had much smaller areas of upgradient urban land use because they were located closer to the western or upgradient edge of York or were infrequently used wells with much lower withdrawal rates. The fact that the study PSW supplied the second largest volume of water to York during 2000-2004 was critical because the effect of receptors (pumping wells) on contaminant movement was an important part of the study design. In addition, most of the other wells were located in closer proximity to other supply wells than the study PSW; in some cases, the simulated zones of contribution for these wells were very complicated (Landon and Turco, 2007) because of withdrawals from nearby supply wells.

\section{Preferential Flow through the Upper Confining Unit}

Geochemical data collected for the HPGW TANC study indicate preferential flow through the upper confining unit. A network of 36 monitoring wells screened at different depths in the unconfined and confined aquifers was installed in the model area (Landon and others, 2007) (fig. 7; table 2). The monitoring wells and the selected the study PSW were sampled for a wide variety of constituents, including chlorofluorocarbon-11 (CFC-11) and other age tracers (Landon and others, 2007). Interpretations of the tracer data indicated that a pistonflow model assumption (Cook and Böhlke, 2000; Landon and others, 2007) appeared to be appropriate for estimating mean age of water collected from monitoring wells in the unconfined aquifer and could be compared to simulated age to evaluate model fit. A piston-flow assumption is based on the concept that ground water that recharges during a particular year does not mix with waters of other ages along the area that contributes water to the sampled well. The original concentration of a tracer in the water at the time of recharge is retained from the recharge area to the sampled well (Cook and Böhlke, 2000). In the upper confined aquifer, age tracer and waterchemistry data indicated that the ground water was a mixture of relatively old, upper confined aquifer water and relatively 


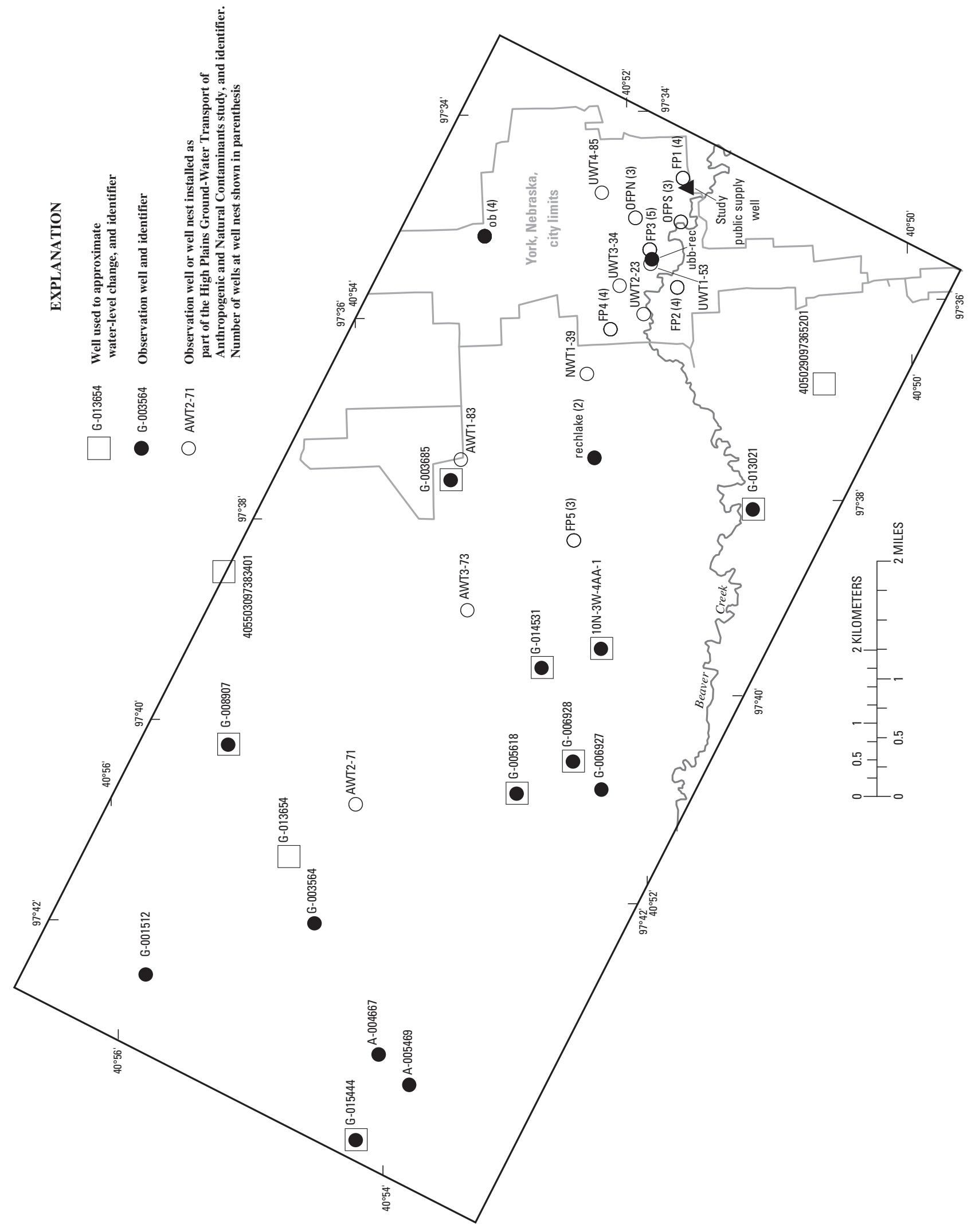

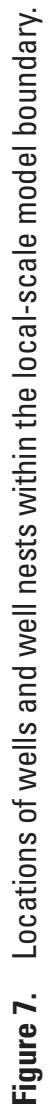




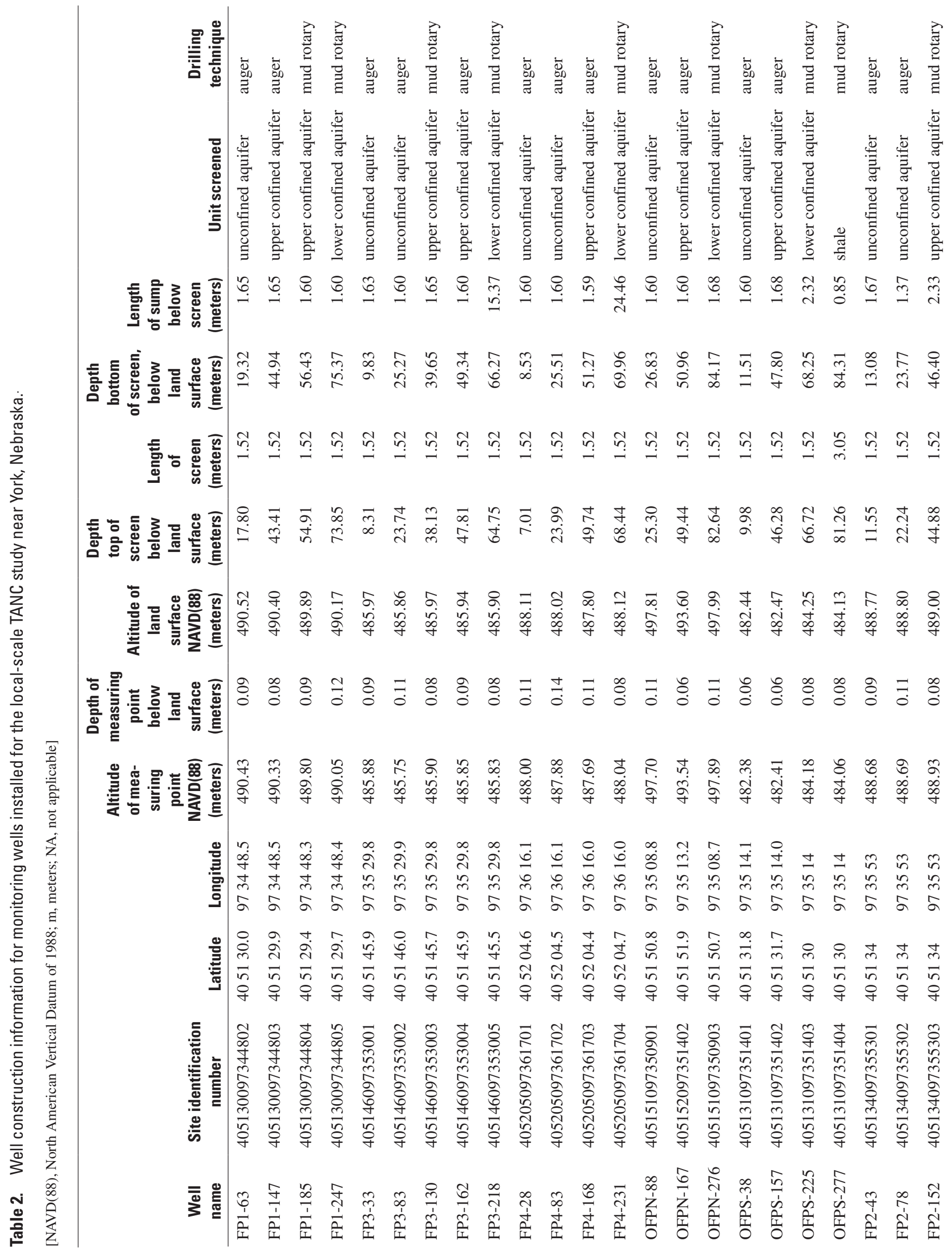




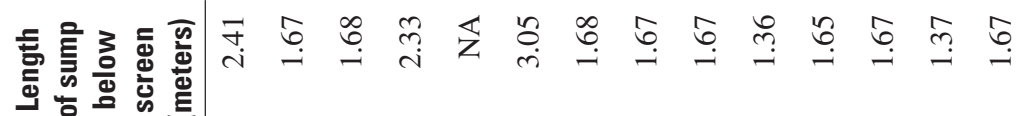

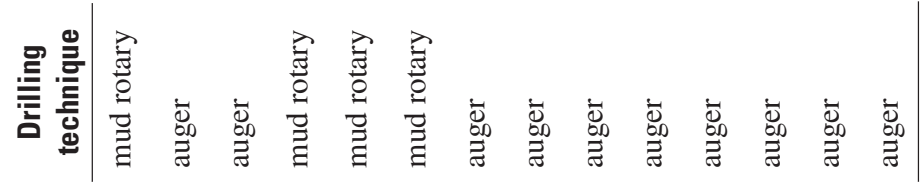

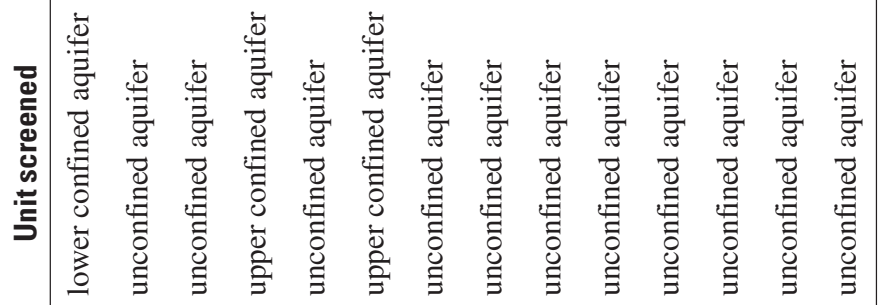

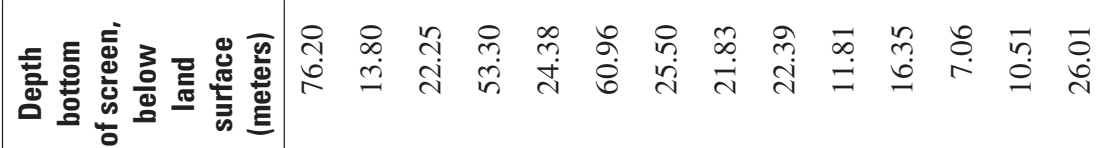

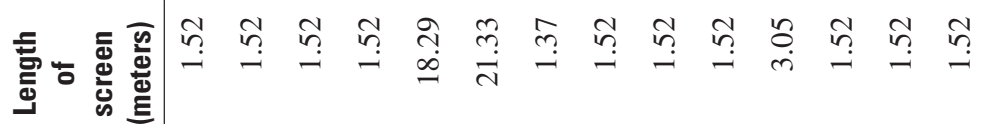

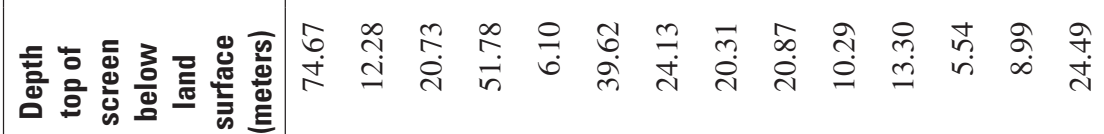

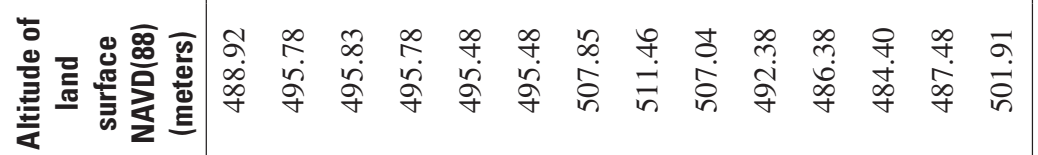

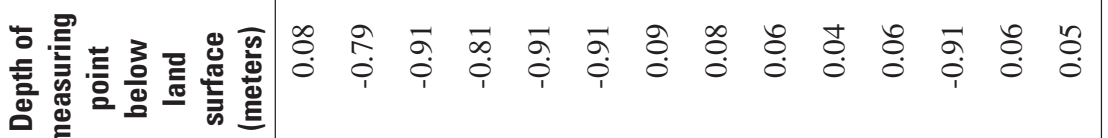

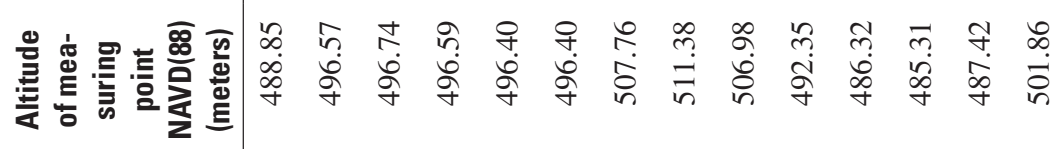

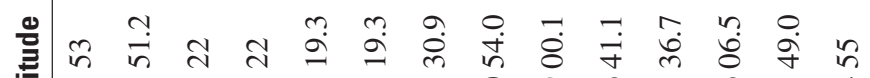

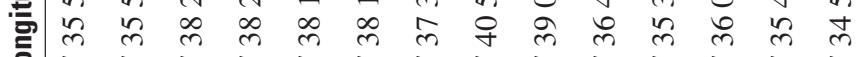

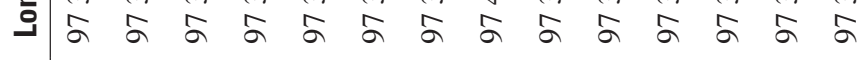

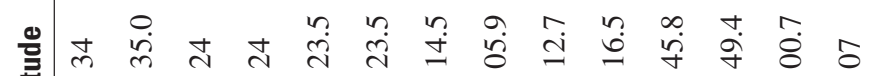

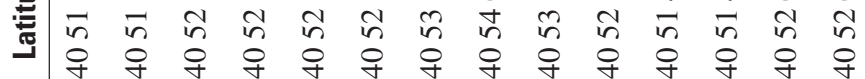

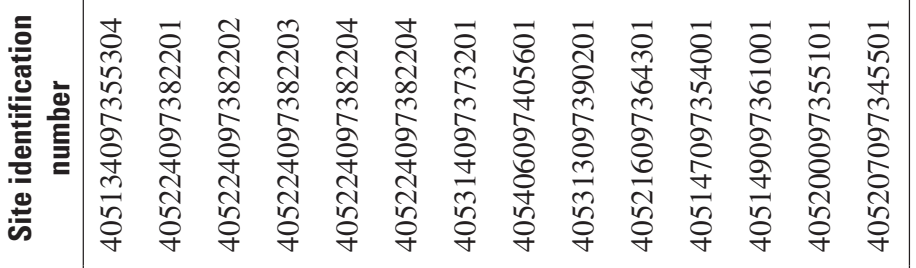

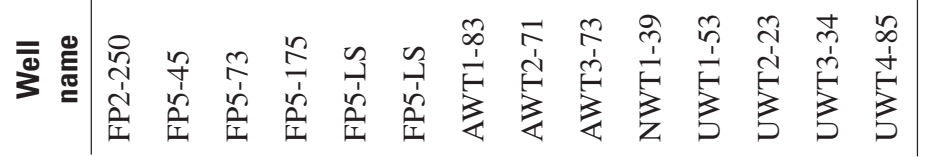


young water from the unconfined aquifer (Landon and others, 2007). Most monitoring wells in the upper confined aquifer contained less than 2 percent young, unconfined aquifer water and contained predominantly old water. Six of nine monitoring wells and the study PSW in the upper confined aquifer had geochemical and isotopic signatures consistent with older, upper confined aquifer water; the other three wells had geochemical and isotopic signatures consistent with mixtures of older, upper confined aquifer water and younger water from the unconfined aquifer (Landon and others, 2007). Of the nine monitoring wells in the upper confined aquifer, age tracers were measured in six of the wells, in addition to the study PSW. In two of these monitoring wells and the study PSW, samples contained 10 to 80 percent young (based on age tracers), unconfined (based on isotopic and geochemical tracers) water. The other four monitoring wells in the upper confined aquifer with age tracer data contained predominantly old (less than 2 percent young based on age tracers), confined (based on isotopic and geochemical tracers) water. Flow measurements and samples also were collected from different depths in the PSW under pumping conditions to determine where water and constituents of concern enter the well screen. The samples from the bottom half of the well screen (which lies below the upper confining unit) had chemical signatures consistent with water derived from shallow recharge areas in the urban area mixed with comparatively older native water from the upper confined aquifer (Landon and others, 2007). This non-uniform distribution of mixed water implies that there are preferential flow paths that permit recharge water and contaminants to move through the upper confining unit.

Interpretations of lithologic and geophysical logs indicate that the upper confining unit is continuous throughout the local-scale model area, giving little indication that natural preferential flow paths through the upper confining unit exist. While the upper confining unit was observed to be continuous across the local-scale model area based upon drill logs from this and previous studies, it is possible that there may be discontinuities in the upper confining unit that have not been identified. If discontinuities are present, they do not appear to be widespread as the upper confining unit was present in approximately 80 available drill logs. Laboratory tests of vertical hydraulic conductivity on cores of the upper confining unit resulted in relatively low $\left(10^{-6} \mathrm{~m} / \mathrm{d}\right)$ values (Landon and others, 2007). These data support a hypothesis that downward leakage of young water from the unconfined aquifer to the upper confined aquifer occurs through well bores of irrigation wells or supply wells that penetrate the upper confining unit. To test this hypothesis that well-bore leakage could explain contaminant distribution in the upper confined aquifer (Landon and others, 2007), a simulation approach that included leakage through well bores was used in the local-scale model area.

\section{Methods for Simulation of Ground- Water Flow and Age}

Models constructed to simulate ground-water flow and age are described and documented in the sections below. The local-scale ground-water flow model was constructed and calibrated, followed by construction of the ground-water transport model within a sub-grid of the ground-water flow model (fig. 1), which was used for direct simulation of ground-water age following methods by Goode (1996), as well as simulation of age tracer concentrations. Thereafter, both models were refined in concert to obtain the most reasonable match of simulated and observed hydraulic heads, ground-water ages, and in the case of confined wells, CFC-11 concentrations (the age tracer with the most data in the confined wells). Because the flow and transport models were refined through an iterative process of running both models, both simulation models are described in the sections below.

\section{Updates to the Regional Model}

The local-scale model documented in this report initially was developed from a regional-scale steady-state groundwater flow model (Landon and Turco, 2007). The regionalscale model was modified to provide inputs for the localscale model boundary conditions. The modifications to the regional-scale model included replacing the Well Package of MODFLOW 2000 with the Multi-Node Well (MNW) Package (Halford and Hanson, 2002). The use of the MNW Package, in turn, required parameter modifications in the regionalscale model to produce the best simulated surface to provide hydraulic heads at the local-scale model boundaries. The use of simulated heads from the regional-scale model is explained in the Boundary Conditions, Model Stresses, and Initial Conditions (Landon and Turco, 2007).

\section{Local-Scale Model Geometry and Discretization}

The USGS modular three-dimensional finite-difference program, MODFLOW-2000 (Harbaugh and others, 2000), was used to simulate flow in the local-scale model. The localscale model area is discretized into a finite-difference grid of 180 rows by 372 columns of uniform cells each $40.2 \mathrm{~m}$ on a side, covering a total of approximately $108.2 \mathrm{~km}^{2}$. The grid is oriented $27^{\circ}$ north of west to approximately coincide with the regional ground-water flow direction from northwest to southeast (Landon and Turco, 2007). The model is a 14-layer representation of one surficial loess unit (unsaturated throughout most of the simulation), three water-bearing units and two confining units within the eastern High Plains aquifer system (fig. 2; table 1). The top layer (layer 1) begins at land surface and represents mostly unsaturated (loess) deposits. Layers 2 through 4 represent the unconfined aquifer. Layers 5 through 9 represent the upper confining unit. Layers 10 through 12 
represent the upper confined aquifer. Layer 13 represents a lower confining unit. Layer 14 represents the lower confined aquifer. The lower confined aquifer is underlain by the Carlile Shale of Colorado Group of Cretaceous age in the southeastern two-thirds of the local-scale model area and the Niobrara Formation of Cretaceous age, consisting of chalky shale and chalk, in the northwestern one-third of the local-scale model area (Keech and others, 1967). The Carlile Shale of Colorado Group and Niobrara Formation are much less permeable than the sands and gravels of the High Plains aquifer system and are considered the base of the High Plains aquifer system, thus they are not simulated in the local-scale model. A more detailed description of the hydrogeology can be found in Landon and Turco (2007).

Surfaces representing the top of each layer were interpolated from about 80 driller and geophysical logs in the regional-scale and local-scale model areas. The surfaces for each of the six major hydrogeologic units originally were generated for the regional-scale model (Landon and Turco, 2007). The bottoms of layers 1 through 6 in the regional-scale model corresponded to the bottoms of layers $1,4,9,12,13$, and 14 in the local-scale model (table 1). Thus, the layer surfaces in the regional-scale model were preserved in the local-scale model, but more layers were added to permit local-scale ground-water flow to be simulated. During the flow-model calibration, dry cells were encountered in layer 2 (unconfined aquifer). The rewetting capability of MODFLOW-2000 was attempted to alleviate the dry cells. However, with the lack of success using the rewetting capability and the increased complexity and solution time for the simulation, rewetting was abandoned in favor of modifying the local-scale model grid. The bottom of layer 2 was re-interpolated to allow for water-table fluctuations throughout the entire simulation period within layer 2 . This was accomplished by setting the bottom of layer 2 equal to the lowest simulated hydraulic head minus $1.5 \mathrm{~m}$. A few individual cells near pumping centers continued to go dry during the simulation and the bottom of layer 2 was adjusted further to allow all cells in layer 2 to remain saturated. This resulted in areas within layers 3 and 4 that were too thin to reliably solve ground-water flow and transport simulations. Therefore, another examination of the top of layer 5 (bottom of layer 4) resulted in re-interpolation (lowering) of that surface. Screen information for wells completed predominantly in the unconfined aquifer was used to lower the top of the upper confining unit for a radius of approximately $305 \mathrm{~m}$ around each well and used to re-interpolate the surface.

Ground-water flow in the High Plains aquifer in the local-scale model is simulated for a 60-year period from September 1, 1944, to August 31, 2004. MODFLOW-2000 allows the user to define steady-state and transient stress periods in the same simulation. Steady-state conditions (stress period 1) are simulated prior to September 1, 1944, and represent conditions before the use of ground water for irrigation. The transient simulation (stress period 2-121) from September 1, 1944 to August 31, 2004 is divided into 120 stress periods for a total of 121 stress periods (fig. 5). There are two annual stress periods, one stress period (with two time steps) representing fall, winter, and spring (9 months) from September through May and one stress period (with one time step) representing the summer irrigation season ( 3 months) from June through August.

\section{Boundary Conditions, Model Stresses, and Initial Conditions}

Model boundary conditions determine the locations and quantities of simulated flow into and out of the model; therefore, the selection of appropriate boundary conditions is a major concern in any modeling effort. Lateral inflows to and outflows from the local-scale model are represented with the flow head boundary (FHB) package (Leake and Lilly, 1997). Specified heads in the FHB package are based on modified simulated heads of the regional-scale model, which represent the time period from 1997-2001 (Landon and Turco, 2007) adjusted up or down each stress period on the basis of the change in hydraulic-head observations. Eleven wells (fig. 7), mostly in the unconfined aquifer within and near the local-scale model boundary, were analyzed for the change in hydraulic head of each well from the respective hydraulic head in each of the 11 wells at a baseline date in the spring of 1996 (fig. 8). The analysis indicated that hydraulic heads changed through time by very similar amounts in different wells. Heads in and near the local-scale model area were primarily rising and falling as a system while preserving the regional hydraulic head gradient, which minimizes spatial variations in changes in heads. To generate boundary hydraulic heads for each transient stress period, an approximation of the change from 1996 hydraulic heads was used to calculate an offset for each stress period to apply to the simulated hydraulic heads extracted from the regional-scale model (Landon and Turco, 2007). Three additional wells screened in the confined aquifers were used to calculate hydraulic-head change through time for the confined aquifers in the local-scale model. Lateral boundaries of layers representing confining units are represented as no-flow boundaries because horizontal flow into and out of confining units from surrounding areas is negligible compared to horizontal flow in aquifers. The base of layer 14 also is represented as a no-flow boundary, because of the comparatively low permeability of the underlying Carlile Shale of Colorado Group and Niobrara Formation.

Areal recharge is applied throughout the local-scale model area using the MODFLOW recharge package (Harbaugh and others, 2000). Four recharge zones (based on land use - urban, non-irrigated, gravity irrigated, and sprinkler irrigated areas) were assigned in the local-scale model (fig. 9). Recharge rates from the regional-scale model were used as the initial values for the local-scale model (Landon and Turco, 2007). Recharge as a fraction (ranging from 14 to 22 percent) of precipitation and irrigation based on typical literature values were estimated and modified during calibration of the regional model. For fall-winter-spring stress periods, the average 


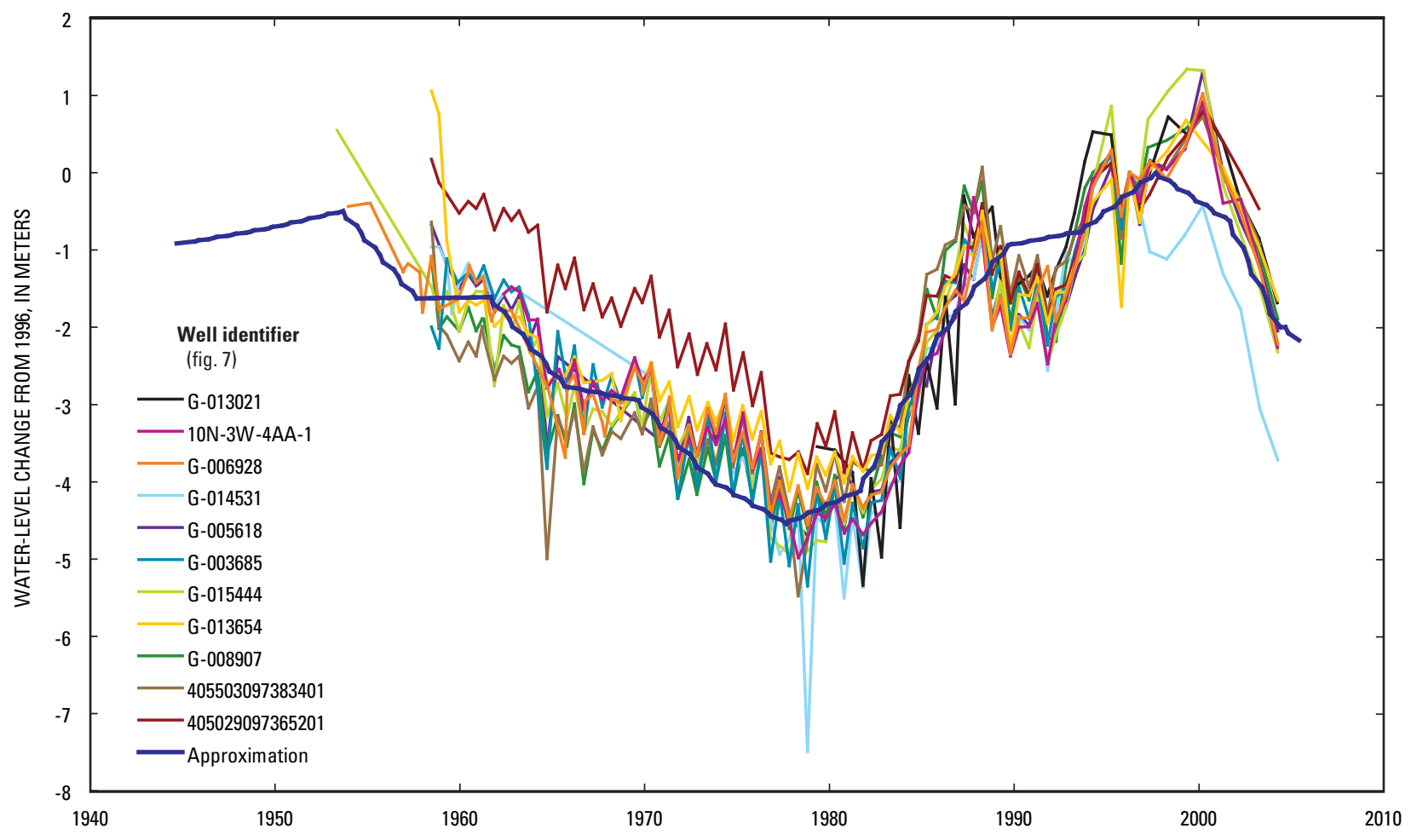

Figure 8. Change in hydraulic heads in wells screened primarily in the unconfined aquifer.

September-May precipitation for each particular year was divided by the average September-May precipitation from 1997 to 2001 (steady-state simulation period of the regionalscale model) to calculate a precipitation-weighted recharge multiplier for each fall-winter-spring stress period. Similarly, for summer stress-periods, average June-August precipitation for each particular year was divided by average June-August precipitation from 1997 to 2001 to calculate a precipitationweighted recharge multiplier for each summer stress period. Recharge for seasonal stress periods was calculated in this way for September 1944 through August 2004. Precipitationweighted recharge multipliers for each stress period then were multiplied by regional-scale model steady-state recharge rates for each land-use category to calculate initial estimates of recharge for the local-scale model. Thus, initial estimates of recharge were precipitation weighted and were based on estimates from the steady-state regional model. These estimates then were modified during local-scale model calibration, in particular to account for historical shifts from non-irrigated to irrigated land use (fig. 10). Initial recharge values for urban land use were held constant throughout the simulation. During calibration, the values of urban recharge were decreased by decade for simplicity to match measured hydraulic heads. The recharge rates in the local-scale model are higher than recharge rates in most of the High Plains aquifer because the local-scale model area is located in the wettest, coolest part of the High Plains aquifer. Precipitation, temperature, and potential evapotranspiration data (Gutentag and others, 1984) indicate that precipitation is greater, temperature is lower, and potential (pan) evaporation is lower in eastern Nebraska, which is in the northeastern corner of the High Plains aquifer, than any other area underlain by the aquifer. These patterns also are evident from maps of Dugan and Zelt (2000). Under these conditions, precipitation recharge is expected to be higher near York, Nebraska, than in most of the High Plains aquifer including the results of McMahon and others (2006), which were conducted at sites with substantially lower precipitation and greater potential evapotransporation.

Irrigation, municipal, and industrial wells are simulated using the MNW Package (Halford and Hanson, 2002). The MNW Package allows simulation of flow in wells that are completed in multiple nodes, or layers. Flow through the well bore of a MNW is distributed dynamically based on transmissivity and hydraulic head differences between the respective layers. The MNW package also allows the user to specify drawdown constraints for each well simulated. Transport simulations were not possible without drawdown constraints because dry cells were produced at some locations. Therefore, drawdown constraints were set to the top of screen for each well in which the screen extended into the unconfined layers to limit withdrawals if the hydraulic head dropped to the top of the screen. Flow into or out of the well bore can be 


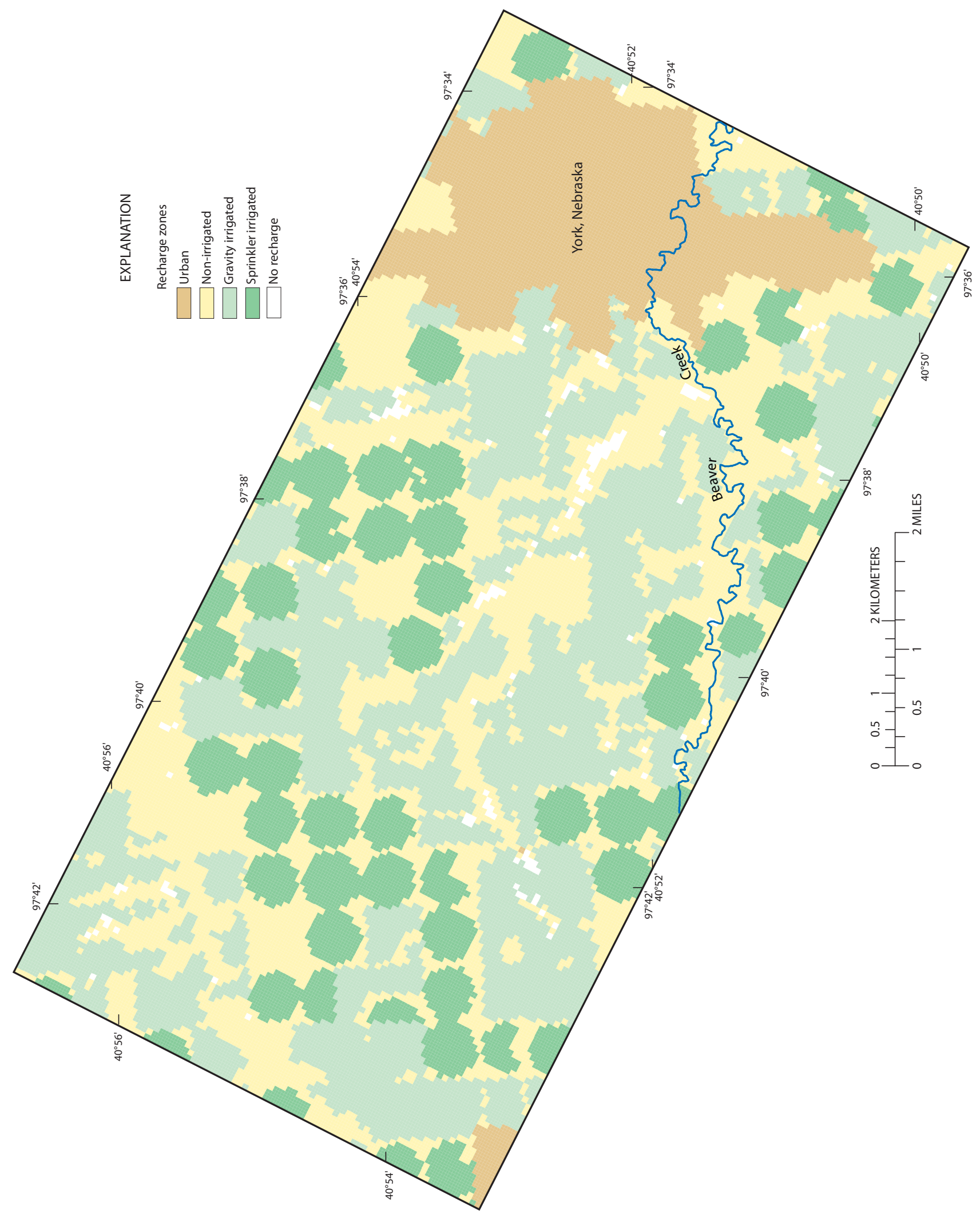

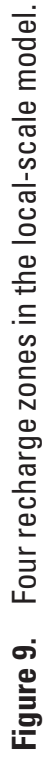




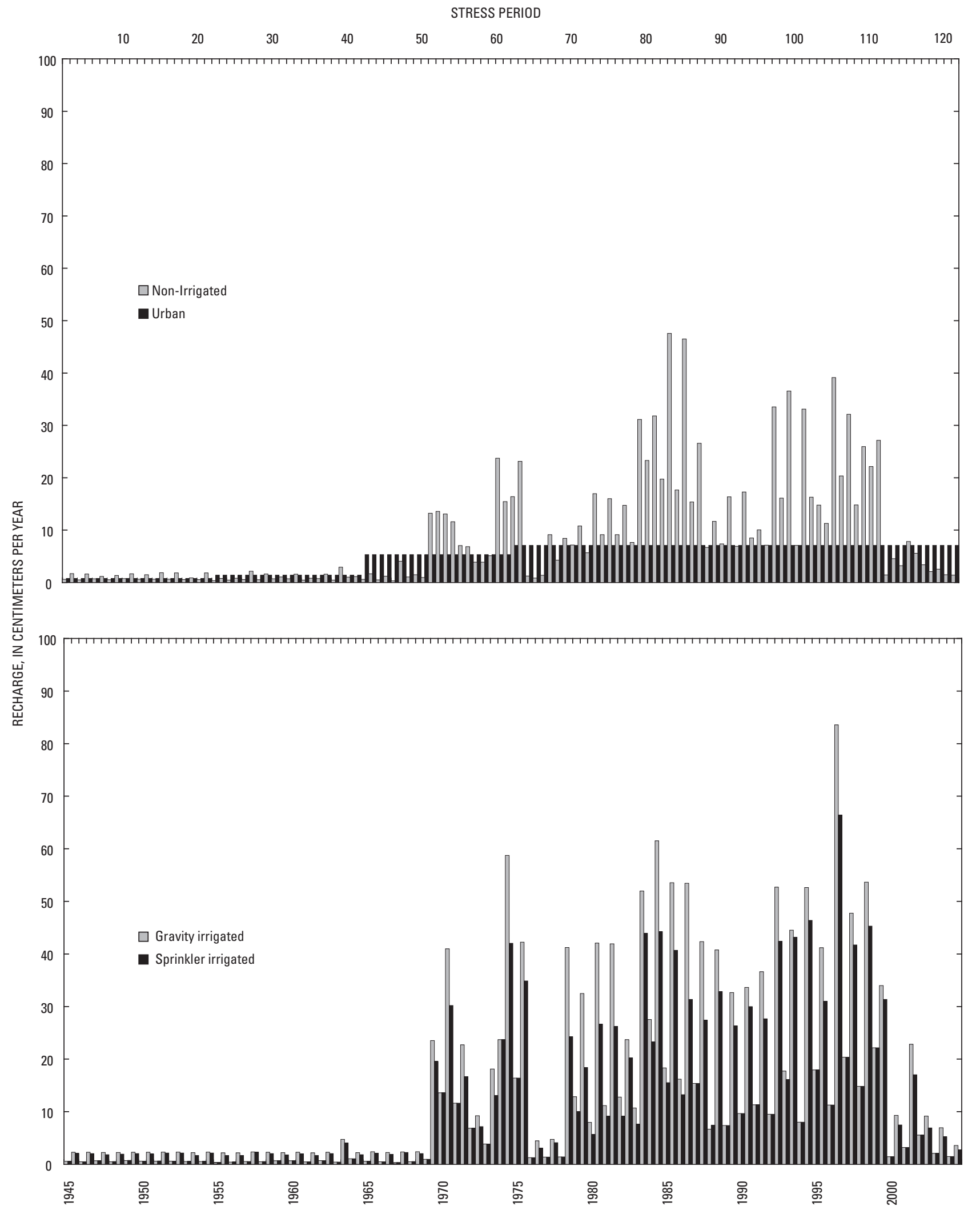

Figure 10. Simulated recharge for the four recharge zones in the local-scale model. 
affected by the contrast in transmissivity between the formation and the disrupted radius around the well bore, noted by a Skin coefficient. For all active withdrawal wells, a final, calibrated Skin value of 4 was used (which results in a contrast of the transmissivity of the formation (T) to transmissivity of the disrupted radius (Tskin) value of 6.77 (T/Tskin)). For all abandoned wells or test holes, a final, calibrated Skin value of 15 was assigned (which results in a T/Tskin value of 22.64) because these well bores should be filled with grout, thus reducing the transmissivity through the well bore. The higher Skin value thus has the effect of restricting flow through multilayer well bores. The final, calibrated Skin values are near the range used by Hanson and others (2004), in which they increased the Skin value from 5 to 15 during calibration. The locations of abandoned wells were determined from the Nebraska well registration (Nebraska Department of Natural Resources, 2003). The locations of abandoned test holes were obtained from the city of York (Orville Davidson, city of York, Nebraska Public Utilities, written commun., 2002). Leakage through abandoned well bores could be caused by incomplete plugging of the well or leakage through the annulus between the casing and formation. In either case, leakage could occur throughout the full length of the drilled well bore. Sixty-three abandoned wells were included as MNWs in the model with zero withdrawal. Each well is simulated as having connection from the uppermost portion to the total depth of the well bore, rather than a screen interval as assigned to other production wells simulated in the model (see "Simulated Flows and Heads" section).

Withdrawals from each multi-node irrigation well were increased or decreased from 1997-2001 steady-state withdrawal rates simulated in the regional-scale model (Landon and Turco, 2007) using a withdrawal multiplier for each stress period. The withdrawal multiplier was based on a linear regression of average seasonal irrigation applications and June-August precipitation. Average annual irrigation withdrawal values for 1998-2002 were compiled by the Upper Big Blue Natural Resources District (UBBNRD) (Rod DeBuhr, Upper Big Blue Natural Resources District, written commun., 2003). Average annual values also were compiled from historical reported irrigation withdrawal data from 1953 (Johnson and Keech, 1959), 1968 (Jess, 1970), and 1971 (Steele, 1973). The latter two withdrawal data sets were from Seward County, immediately east of York County, with similar climate and land use. Data from UBBNRD and Johnson and Keech (1959) were collected across the entire UBBNRD area, which includes York and Seward Counties. Spatial variations in average irrigation withdrawal rates across the UBBNRD were expected to be considerably smaller than year-to-year variations in irrigation withdrawal rates in response to climatic variations. Linear regressions between historical application rates for irrigation and summer (June-August) precipitation were developed and are shown on figure 11. Summer precipitation and irrigation withdrawal shows a significant inverse correlation (Spearman's rho $=-0.95, \mathrm{p}=0.011, \mathrm{R}^{2}=0.64$ ). The $\mathrm{R}^{2}$ value of 0.64 indicates that much of the variation in seasonal

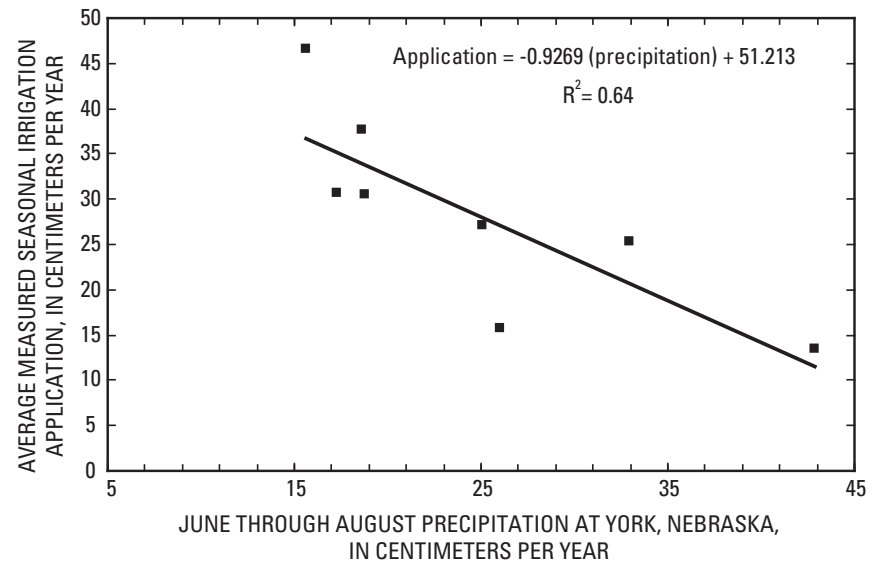

Figure 11. Linear regression of average measured seasonal irrigation application and June-August precipitation at York, Nebraska.

rrigation withdrawal can be explained by summer precipitation. This linear regression then was used to estimate historical expected ground-water withdrawal rates for irrigation based on summer precipitation for York (High Plains Climate Center, 2003) (fig. 6). Finally, this value for each summer stress period was multiplied by the ratio of the number of registered wells in existence at the time of each stress period divided by the cumulative number of wells in existence in 2002, the end of the regional-scale model steady-state simulation period (Nebraska Department of Natural Resources, 2003). The resulting value scaled the irrigation withdrawals per irrigated area for summer precipitation and historical changes in irrigation development. These scaled irrigation withdrawals were assigned uniformly to all sprinkler and gravity irrigated areas. Withdrawals from industrial and municipal wells were included based on water-use records from the city of York. Industrial and municipal withdrawals are evident during winter months when irrigation withdrawals are zero (fig. 6).

There are no natural perennial streams in the HPGW TANC study area. However, a commercial facility discharges water to Beaver Creek in southwestern York, and the York wastewater-treatment plant discharges water into Beaver Creek in southeastern York. These discharges have the potential to act as recharge to the aquifer by leaking through the streambed. Streamflow measurements along the creek and discharge measurements from the commercial facility and wastewatertreatment plant allow for estimates of streamflow loss to the aquifer (Landon and others, 2007). These estimates were used to compare to simulated streamflow loss in the local-scale model using the MODFLOW River Package (Harbaugh and others, 2000), though the comparison was not quantified in the statistical analysis. Because the commercial facility was not built until the 1960's, the river stage is set equal to the river bottom prior to 1968 . After 1968, the river stage is set to $0.3048 \mathrm{~m}$ above the river bottom, indicating water in Beaver Creek because of the artificial discharges. The local-scale 
model grid is a horizontal refinement of $4: 1$ of the regionalscale model grid. Because the river lengths remained the same as in the regional-scale model, but now occurred in four times as many model cells, the streambed conductance factor was reduced by a factor of 4 to be equivalent to that used in the regional-scale model. Streambed conductance was further modified during the local-scale model calibration. The streambed conductance factor is the product of the streambed hydraulic conductivity and the streambed width divided by the thickness of the streambed material. The streambed conductance factor of the creek was modified from the initial value to produce streamflow loss values from the stream to the aquifer within a range of estimated streamflow loss values. The streambed conductance factor in the local-scale model was calculated using a bed thickness of $0.3048 \mathrm{~m}$, a stream channel width of $3.048 \mathrm{~m}$, and final, calibrated streambed hydraulic conductivity of $0.05 \mathrm{~m} / \mathrm{d}$, yielding a streambed conductance factor of $0.5 \mathrm{~m}^{2} / \mathrm{d}$. Similar methods were used to include the upper portion of the creek, west of York, which is simulated in the local-scale model using the MODFLOW Drain Package (Harbaugh and others, 2000), because this part of the creek is dry except after rainstorms. For the drain, a bed thickness of $0.3048 \mathrm{~m}$, a stream channel width of $3.048 \mathrm{~m}$, and a final streambed hydraulic conductivity of $0.025 \mathrm{~m} / \mathrm{d}$ were assumed, yielding a streambed conductance factor of $0.25 \mathrm{~m}^{2} / \mathrm{d}$. The streambed conductance factor was multiplied by the length of the stream reach in each drain and river cell to calculate the streambed conductance. The streambed conductance factor of the drain was varied during calibration; however, the value of $0.25 \mathrm{~m}^{2} / \mathrm{d}$ yielded the best match to measured hydraulic heads.

Initial conditions are simulated with a steady-state stress period (representing conditions prior to September 1, 1944) at the beginning of the simulation. FHB hydraulic heads for the steady-state stress period are the same as from September 1944 to September 1945. Hydraulic heads specified by the FHB Package can vary at any time throughout a stress period. This capability allows a smooth transition of boundary hydraulic heads from one stress period to the next. Thus, hydraulic heads are updated for June, September, and November (added to smooth the effects of summer to winter hydraulic head conditions) of each year throughout the simulation. Recharge for the first stress period is the same as used in the second stress period. There are no withdrawals specified in the first stress period because it is designed to represent predevelopment conditions before pumping began.

\section{Model Hydraulic Parameters}

In many models, grid cells assumed to have similar hydrologic properties are grouped together as a parameter zone and assigned a value that can be adjusted during the calibration process (Hill and others, 2000). The local-scale ground-water flow model uses a total of 24 hydraulic parameters (table 1). These parameters include horizontal hydraulic conductivity, vertical anisotropy, specific yield, and specific storage (table 1). Initial model simulations were made using hydraulic conductivity and vertical anisotropy values from the regional-scale model, which were based on aquifer tests, literature values, and adjustments made during model calibration (Landon and Turco, 2007). All parameter values are areally uniform within a layer across the local-scale model; parameters were only varied vertically by layer. The model was calibrated by making manual changes to parameter values and examining residuals for hydraulic heads, ground-water age, and CFC-11 concentrations (see the "Model Parameters for Simulating Ground-Water Age and CFC-11 Concentrations" section of this report). Recharge was adjusted by changing multipliers to acquire the best fit possible of the mean values of residuals throughout the simulation time. The ratio of vertical to horizontal hydraulic conductivity was adjusted primarily in the unconfined aquifer and upper confining unit. Manual adjustments of hydraulic conductivity, vertical anisotropy, and storage were made to reduce the root mean squared error (RMSE) of residuals and reduce the maximum and minimum residual values.

Simulated heads were compared to 470 hydraulic-head measurements from 53 wells in the local-scale model area. Values of mean, minimum, maximum, absolute mean residuals, and RMSE were computed for each year from residuals (table 3). RMSE in meters is determined using the equation:

$$
R M S E=\left[\sum\left(h_{o}-h_{s}\right)^{2} / n\right]^{0.5}
$$

Where ho is observed hydraulic head, in meters, $h s$ is simulated hydraulic head, in meters, and $n$ is number of observations.

Values of horizontal hydraulic conductivity for layers 2-4, which represent the unconfined aquifer, were adjusted to accommodate a fining-downward sequence of sediments evident from lithologic descriptions, geophysical logs, and slug tests (Landon and others, 2007). Final calibrated horizontal hydraulic conductivity values in the unconfined aquifer decreased from $55 \mathrm{~m} / \mathrm{d}$ in layer 2 to $12 \mathrm{~m} / \mathrm{d}$ in layer 4 (table 1). Horizontal hydraulic conductivity in the upper confined aquifer also was modified for a better fit to depth-dependent flow sampling of the supply well, and chemistry and age tracer data. These data indicated a higher hydraulic conductivity near the middle of the upper confined aquifer with a value of 15 $\mathrm{m} / \mathrm{d}$ sandwiched by a value of $6.1 \mathrm{~m} / \mathrm{d}$ at the top and bottom.

Values of vertical anisotropy, specific yield, and specific storage were similarly assigned considering vertical changes in lithology. Vertical anisotropy was modified from the regionalscale model in the unconfined aquifer, upper confining unit, and upper confined aquifer throughout the calibration process. Simulated hydraulic head and ground-water ages were found to be sensitive to the value of vertical anisotropy, particularly in the upper confining unit. 
Table 3. Residual statistics for model calibration.

\begin{tabular}{|c|c|c|c|c|c|}
\hline Year & $\begin{array}{c}\text { Mean of } \\
\text { residuals } \\
\text { (meter) }\end{array}$ & $\begin{array}{l}\text { Minimum of residu- } \\
\text { als (meter) }\end{array}$ & $\begin{array}{l}\text { Maximum of residu- } \\
\text { als (meter) }\end{array}$ & $\begin{array}{l}\text { Root mean square } \\
\text { error of residuals } \\
\text { (meter) }\end{array}$ & $\begin{array}{l}\text { Mean absolute of } \\
\text { residuals (meter) }\end{array}$ \\
\hline 1953 & 0.33 & -3.76 & 3.07 & 3.01 & 2.21 \\
\hline 1957 & -0.22 & -0.22 & -0.22 & -- & 0.22 \\
\hline 1958 & -1.80 & -2.19 & -1.42 & 2.60 & 1.80 \\
\hline 1959 & -0.60 & -3.23 & 0.96 & 1.71 & 1.23 \\
\hline 1960 & -1.44 & -2.11 & -0.77 & 2.25 & 1.44 \\
\hline 1961 & 0.08 & -2.88 & 3.62 & 1.98 & 1.54 \\
\hline 1962 & -0.12 & -2.78 & 1.12 & 1.57 & 1.26 \\
\hline 1963 & -0.27 & -2.75 & 1.29 & 1.73 & 1.45 \\
\hline 1964 & 0.09 & -2.28 & 1.41 & 1.48 & 1.24 \\
\hline 1965 & -0.42 & -2.66 & 0.98 & 1.62 & 1.23 \\
\hline 1966 & -0.41 & -2.66 & 1.26 & 1.76 & 1.44 \\
\hline 1967 & -0.25 & -2.86 & 1.41 & 1.90 & 1.51 \\
\hline 1968 & -0.44 & -2.70 & 1.38 & 1.78 & 1.40 \\
\hline 1969 & -1.61 & -2.53 & -0.68 & 2.62 & 1.61 \\
\hline 1970 & 0.17 & -2.73 & 1.36 & 1.45 & 1.20 \\
\hline 1971 & -0.12 & -2.96 & 1.24 & 1.31 & 0.92 \\
\hline 1972 & -0.29 & -3.32 & 1.16 & 1.42 & 0.94 \\
\hline 1973 & -0.25 & -0.88 & 0.78 & 0.94 & 0.76 \\
\hline 1974 & 0.12 & -2.75 & 1.56 & 1.34 & 1.05 \\
\hline 1975 & 0.20 & -2.55 & 1.56 & 1.22 & 0.82 \\
\hline 1976 & 0.03 & -2.75 & 1.52 & 1.24 & 0.75 \\
\hline 1977 & -0.10 & -2.41 & 2.00 & 1.25 & 0.84 \\
\hline 1978 & -0.06 & -2.93 & 1.99 & 1.61 & 1.15 \\
\hline 1979 & -0.03 & -2.12 & 2.09 & 1.23 & 0.89 \\
\hline 1980 & 0.02 & -2.04 & 2.10 & 1.40 & 1.14 \\
\hline 1981 & 0.02 & -2.40 & 2.13 & 1.37 & 0.98 \\
\hline 1982 & -0.26 & -2.65 & 1.92 & 1.41 & 0.93 \\
\hline 1983 & 0.02 & -2.18 & 1.99 & 1.29 & 0.95 \\
\hline 1984 & -0.01 & -2.40 & 2.37 & 1.44 & 1.01 \\
\hline 1985 & 0.05 & -2.79 & 2.47 & 1.49 & 1.08 \\
\hline 1986 & -0.07 & -2.57 & 2.20 & 1.50 & 1.05 \\
\hline 1987 & 0.07 & -2.37 & 2.36 & 1.50 & 1.12 \\
\hline 1988 & 0.47 & -2.07 & 2.46 & 1.52 & 1.21 \\
\hline
\end{tabular}


Table 3. Residual statistics for model calibration.-Continued

\begin{tabular}{llcccc}
\hline & $\begin{array}{c}\text { Mean of } \\
\text { residuals } \\
\text { (meter) }\end{array}$ & $\begin{array}{c}\text { Minimum of residu- } \\
\text { als (meter) }\end{array}$ & $\begin{array}{c}\text { Maximum of residu- } \\
\text { als (meter) }\end{array}$ & $\begin{array}{c}\text { Root mean square } \\
\text { error of residuals } \\
\text { (meter) }\end{array}$ & $\begin{array}{c}\text { Mean absolute of } \\
\text { residuals (meter) }\end{array}$ \\
\hline 1989 & -0.05 & -2.75 & 2.41 & 1.46 & 1.01 \\
1990 & -0.23 & -2.94 & 2.13 & 1.37 & 0.86 \\
1991 & -0.16 & -2.91 & 1.78 & 1.40 & 0.92 \\
1992 & -0.30 & -2.90 & 1.47 & 1.25 & 0.81 \\
1993 & -0.26 & -2.82 & 1.80 & 1.36 & 0.90 \\
1994 & -0.07 & -2.83 & 1.54 & 1.29 & 0.98 \\
1995 & 0.11 & -2.43 & 2.05 & 1.47 & 1.10 \\
1996 & -0.10 & -2.69 & 1.96 & 1.42 & 1.01 \\
1997 & 0.10 & -1.39 & 1.89 & 1.12 & 0.89 \\
1998 & -0.33 & -2.62 & 1.85 & 1.60 & 1.36 \\
1999 & -0.13 & -3.00 & 2.22 & 1.56 & 1.16 \\
2000 & 0.12 & -2.21 & 2.44 & 1.35 & 1.01 \\
2001 & 0.12 & -2.02 & 1.69 & 1.22 & 0.94 \\
2002 & 0.23 & -2.39 & 2.25 & 1.37 & 1.00 \\
2003 & 0.10 & -2.74 & 3.12 & 1.42 & 1.03 \\
2004 & -0.26 & -3.11 & 2.96 & 1.13 & 0.79 \\
& Statistics for all observations & -3.76 & & & 1.37 \\
\hline
\end{tabular}

Specific yield and specific storage values are not required for steady-state conditions but needed to be determined for the transient local-scale model. Initial estimates of specific yield and specific storage were based on literature values (Fetter, 1994; Freeze and Cherry, 1979) and were adjusted during model calibration. Final specific yield values (corresponding also to porosity values in the local-scale model) vary from 0.2 to 0.25 for the unconfined aquifer. Specific storage values range from $6.56 \times 10^{-7}$ per meter in the unconfined aquifer to $9.84 \times 10^{-5}$ per meter in the lower confining unit. The final parameter values for the calibrated model are consistent with available data for the type of material and conditions found in the eastern High Plains aquifer system (Luckey and others, 1986).

\section{Model Parameters for Simulating Ground-Water Age and CFC-11 Concentrations}

Comparison of simulated and interpreted ground-water ages and ground-water age tracer concentrations provides independent information for refining model calibration beyond calibration based on matching simulated and observed hydrau- lic heads. Ground-water age and CFC-11 were simulated within a transport model sub-grid of the local-scale model (fig. 1) using the Ground-Water Transport (GWT) package of MODFLOW-2000 (Konikow and others, 1996). The current version of MODFLOW-GWT allows particle tracking through well bores simulated with the MNW package (Konikow and Hornberger, 2006).

Initial conditions for the age simulations were based on an age profile interpreted from age tracer data from a representative well cluster (FP4) in the local-scale model area that did not appear to be affected by well-bore leakage based on geochemical, isotopic, and age tracer data (Landon and others, 2007). The ages were interpreted from helium-tritium and $\mathrm{CFC}$ data in the unconfined aquifer, CFC data in the upper confined aquifer, and uncorrected carbon-14 data from the lower confined aquifer (Landon and others, 2007). Interpreted ages at four discrete monitoring well depths were interpolated vertically between wells, assuming relatively small vertical age gradients through high hydraulic conductivity sand layers and large vertical age gradients through confining units. The interpolated age profile then was used as the initial age for each layer in the local-scale model and at the model boundar- 
ies throughout the simulation. The age profile at the boundaries was included using the FHB package and does not change through time (table 1). Model simulations using differing age boundary conditions indicated that simulated ages in the area of measured ages within and immediately to the west of the York urban area were not sensitive to reasonable variations in assigned ages at the boundary. This result implies that the boundaries are far enough away from the area of interest and have little effect on the simulated ground-water ages.

Simulated ground-water age was compared to interpreted ages from CFC and helium-tritium data for the unconfined aquifer. As interpreted ages based upon tracer concentrations are affected by mixing (see "Preferential Flow through the Upper Confining Unit" section), it was not possible to meaningfully compare simulated age and interpreted mean age from tracer data in mixed waters in the upper confined aquifer. Rather, the concentration of the age tracer with the most data in the upper confined aquifer, CFC-11, was simulated for direct comparison with CFC-11 concentrations measured in monitoring wells for the purpose of evaluating model fit. Even though CFC-11 is known to degrade under sulfate-reducing conditions (U.S. Geological Survey, 2005), which were present in places in the upper confined aquifer, there was no evidence that CFC-11 degradation in the upper confined aquifer was occurring. If CFC-11 was degrading in the upper confined aquifer, a consistent pattern of younger CFC-12 dates than CFC-11 dates should have been observed. However, CFC-11 results in the upper confined aquifer were generally similar to those for CFC-12, which degrades less than CFC-11. Samples (two) that did indicate evidence of degradation were from wells screened in the unconfined aquifer. In transport simulations, comparisons of simulated CFC-11 concentrations were made only with samples from the upper confined aquifer. The input function for CFC-11 was the historical global atmospheric CFC-11 concentration converted to the expected concentration in recharge water at York, Nebraska, for the recharge temperature estimated from dissolved gas data (Landon and others, 2007; Busenburg and Plummer, 1992; U.S. Geological Survey, 2005).

Apart from test simulations, dispersion was not directly simulated with the transport model because well-bore leakage results in far greater spreading of young water than would occur from dispersion. It was not necessary to add dispersion in order to match simulated and interpreted ground-water age and tracer concentrations.

Initial porosity values were estimated from literature values (Fetter, 1994; Freeze and Cherry, 1979) and were varied during model calibration. Final porosity values of the transport model range from 0.15 to 0.25 in the aquifers of the system to 0.35 in the confining units of the system.

\section{Alternative Model Construction}

In addition to flow and transport simulations under transient conditions with multi-node pumping wells (referred to hereafter as the calibrated model), three alternative models were constructed. The alternative models were used to examine the effects of alternative conceptualizations of the physical system on simulation results.

The first alternative model (without abandoned well model) was identical to the calibrated model, except that all registered abandoned wells and test holes were excluded from the simulation to test the sensitivity to multilayer leakage in these inactive well bores. The second alternative model (well model) used the Well Package of MODFLOW-2000 in place of the MNW package. The well model, which does not simulate flow through well bores, did not successfully complete the simulation (did not converge) with all other hydraulic parameters set at the same value as the calibrated model. Vertical anisotropy through the upper confining unit was lowered from 35 to 30 , thereby allowing more flow through the confining unit. This allowed the simulation to run to completion using the same convergence criteria as the calibrated model. The third alternative model (steady-state model) was constructed as a steady-state simulation representing 1997-2001 conditions similar to the regional-scale model (Landon and Turco, 2007) to examine the differences and importance of simulating transient conditions. The primary changes from the calibrated model were that average values for withdrawal, recharge, and boundary heads representing 1997-2001 were used. A particletracking simulation using the steady-state model to characterize the contributing area for the supply well is described in the following section.

In all three alternative models, ground-water age and CFC-11 transport also were simulated and compared to the calibrated model. For the steady-state model, the simulation of CFC-11 involved including 120 steady-state stress periods identical in length to the transient stress periods of the calibrated model to allow different input concentrations of $\mathrm{CFC}-11$ through the recharge and river packages. Each of the 120 steady-state stress periods used average values for withdrawal, recharge, and boundary heads representing 1997-2001.

\section{Design of Particle-Tracking Simulations}

Particle tracking can be used to calculate the path a particle of water would follow through the simulated groundwater system along with the distance, velocity, and traveltime along this path. The contributing recharge area, zone of contribution, and the areal extent of the zone of contribution for a well can be delineated using this information. The contributing recharge area is defined as the surface area on the three-dimensional boundary of the ground-water system that delineates the location where water that eventually flows to the well enters the ground-water system. The zone of contribution is the three-dimensional volumetric part of the aquifer through which ground water flows to the discharging well from the area contributing recharge (Reilly and Pollock, 1993; Morrissey, 1989). The vertical projection of the zone of contribution to the land surface is termed the areal extent of the zone of 
contribution. Particle tracking was simulated using version 4.3 of MODPATH (Pollock, 1994). Particle tracking utilized output from the steady-state model.

The general approach used the forward-tracking option of MODPATH. Particles were started at all inflow locations in the model, including areal recharge, fluxes from boundaries and the river, and flow from MNWs, and tracked to their discharge point. The particles were uniformly distributed on the face of the model cells associated with the inflow. The volume associated with each particle was computed by dividing the inflow at the source face by the number of particles started on that face. The subset of particles that terminated at a well was used to define the area contributing recharge to that well. The volumes and traveltimes associated with those particles could then be used to calculate the distribution of ages entering a well. Particles that originated from boundary cells were assigned a starting age based on the originating layer. The assigned ages were identical to those used for the boundary cells in the GWT simulation (previously discussed in the "Model Parameters for Simulating Ground-Water Age and CFC-11 Concentrations" section).

An additional complexity in the particle-tracking simulation is that many particles traveling to the supply well begin in the unconfined aquifer, travel down well bores, and then travel through the upper confined aquifer to the supply well. MODPATH was not designed to accommodate particle tracking through well bores. For a more detailed description of the approach used to compute traveltimes of particles moving through well bores, see appendix 1.

\section{Flow and Transport Model Uncertainties and Limitations}

An understanding of model limitations is essential to effectively use flow and age simulation results. The accuracy of ground-water models is limited by simplification of complexities within the flow system, by space and time discretization effects, and by assumptions made in the formulation of the governing flow equations. Model accuracy also is limited by cell size, number of layers, accuracy of boundary conditions, accuracy and availability of data on hydraulic properties, accuracy of withdrawal and areal recharge estimates, historical data for calibration, parameter sensitivity, and by the interpolations and extrapolations that are inherent in using data in a model. Although a model might be calibrated, the calibration parameter values are not unique in yielding acceptable distributions of hydraulic head.

Additional uncertainty exists in regard to the transport model and MODPATH particle-tracking simulations where assumed boundary conditions may affect the result. Such is the case for the age distribution of particles entering the supply well. A portion of those particles were found to originate from the boundary itself, therefore, initial estimated ages (table 1) were assigned to each particle instead of having the model cal- culate traveltime. Also, because these particles originated from a boundary, the complete contributing recharge area could not be delineated.

\section{Flow and Transport Model Calibration Results}

The results of the local-scale flow and transport simulations are presented in the following sections. In addition, comparisons are made between the calibrated model using GWT, the steady-state model using GWT, and the steady-state model using MODPATH.

\section{Flow Model Calibration Results}

Values of RMSE between simulated and measured hydraulic heads ranged from $0.94 \mathrm{~m}$ in 1973 to $3.01 \mathrm{~m}$ in 1953 , though only four RMSE values are greater than $2 \mathrm{~m}$ for the entire simulation period (table 3). The RMSE for all 470 observations is $1.37 \mathrm{~m}$ over a range in observed hydraulichead altitudes from $470.6 \mathrm{~m}$ to $502.6 \mathrm{~m}$. The mean or average of residuals indicates model bias depending on the magnitude and direction of the mean away from zero. The closer the mean is to zero, indicating a balance between positive and negative residuals, the less model bias occurs. A negative mean indicates the model tends to overpredict (simulated hydraulic heads greater than observed), and a positive mean indicates underprediction (simulated hydraulic heads less than observed). The mean residual approached zero with an absolute value less than $0.5 \mathrm{~m}$ for all but 4 years. Out of 470 observations, 250 residuals were greater than or equal to zero (underprediction) and 220 residuals were less than zero (overprediction), resulting in a mean residual of $-0.09 \mathrm{~m}$. The maximum and minimum residuals were $3.62 \mathrm{~m}$ and $-3.76 \mathrm{~m}$, respectively.

The simulated and observed hydrographs, representative of hydraulic heads in the unconfined and upper confined aquifer, show good agreement for most locations with relatively long periods of record (fig. 12). Those with a poorer fit to observed conditions (G-013021 and ob-1) predict higher hydraulic heads throughout the period of measurement. Both wells also are screened primarily in the unconfined aquifer at the eastern end of the local-scale model area (fig. 7). However, both simulated hydrographs maintain a similar shape to the observed hydrograph and both are within 2-3 $\mathrm{m}$ of the observed value throughout the simulation period (fig. 12).

\section{Simulated Flows and Heads}

Simulated flow is primarily from the northwest to southeast as dictated by specified boundary heads in the model (fig. 13A). Vertical hydraulic heads in the study PSW vary by approximately $0.1 \mathrm{~m}$ in the three layers representing the upper 

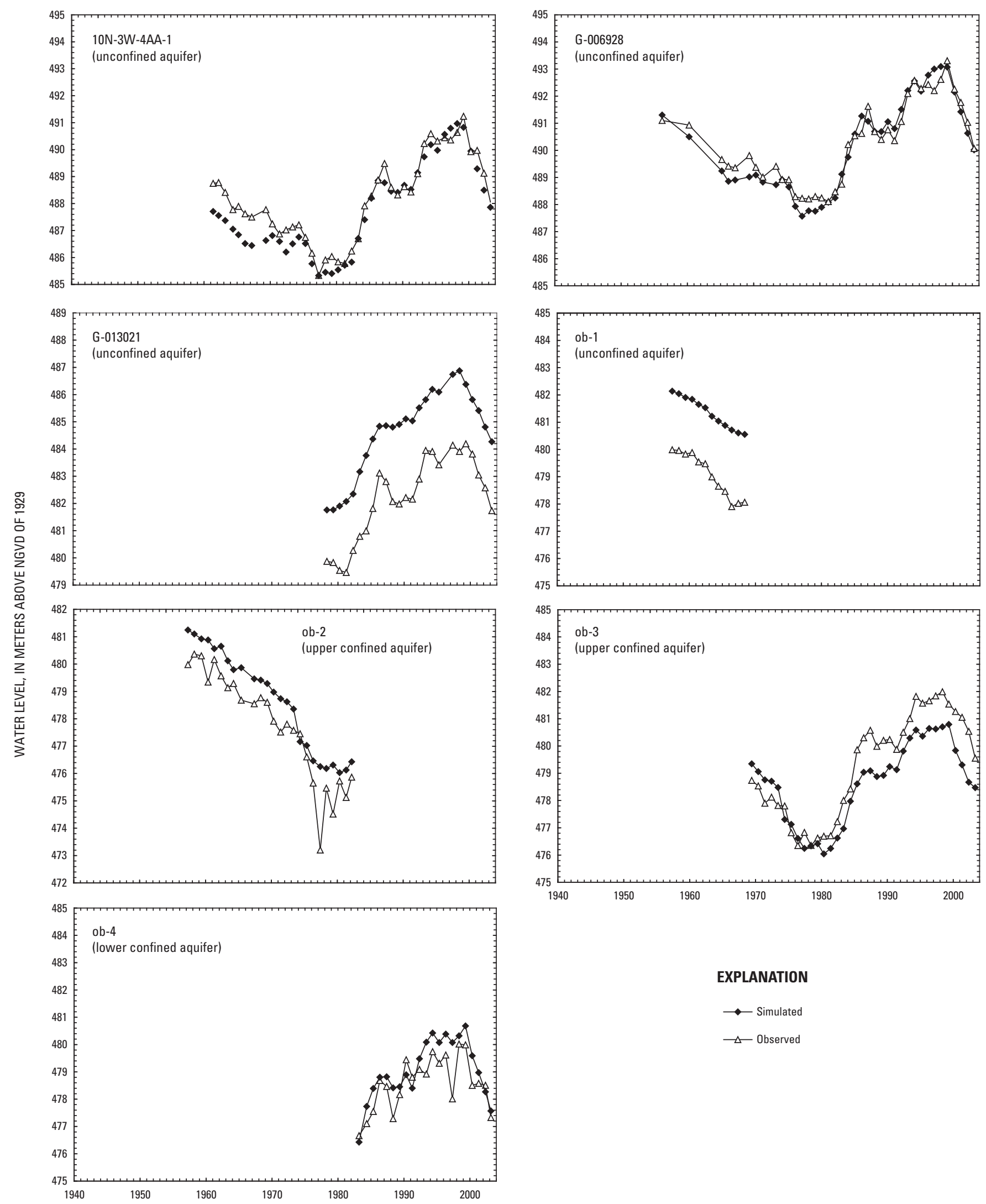

\section{EXPLANATION}

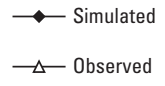

Figure 12. Graphs of simulated and observed hydrographs. 


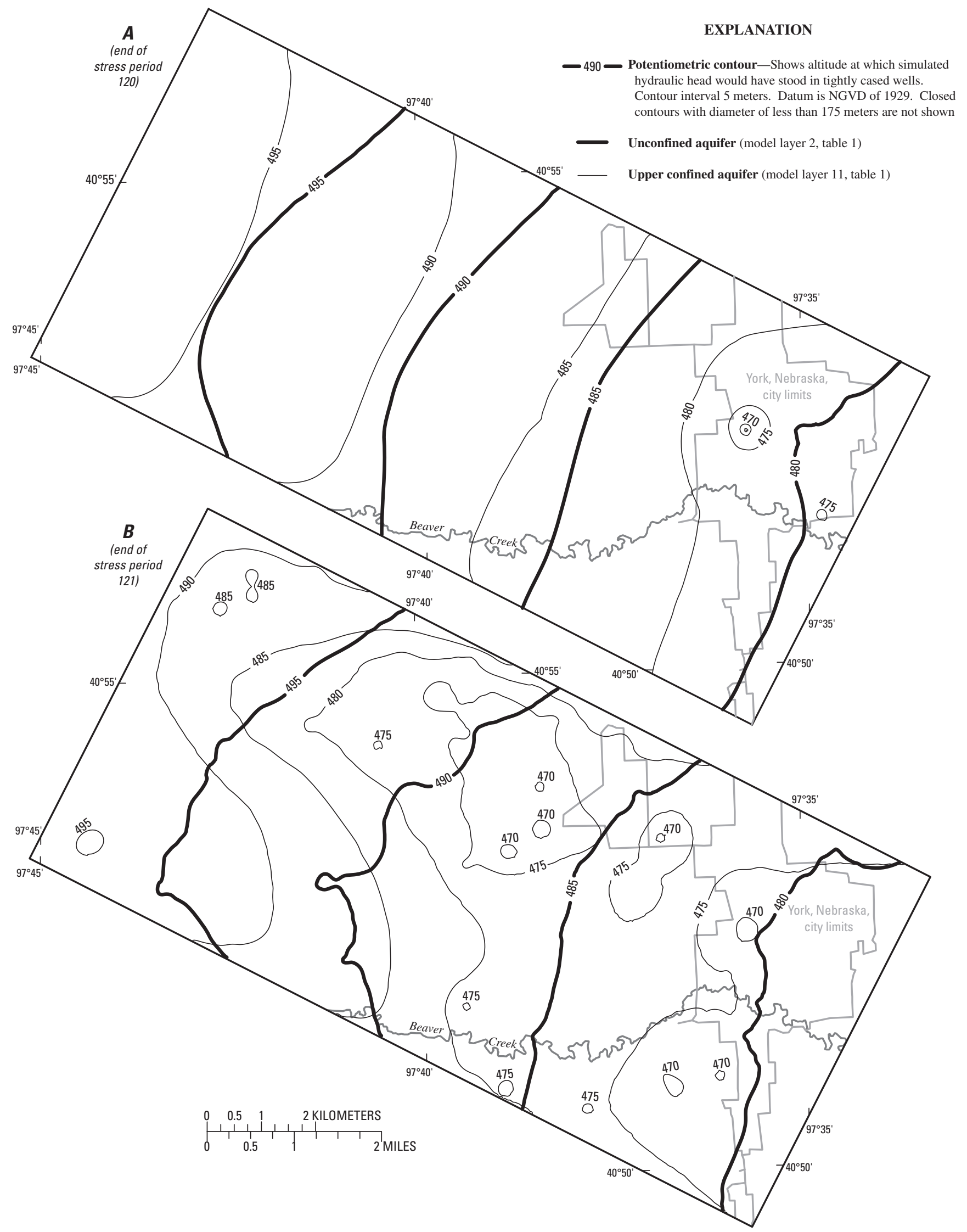

Figure 13. Contours of simulated hydraulic heads of the unconfined and upper confined aquifers for the stress period ending in the spring of 2004 (A) and summer of 2004 (B). 
confined aquifer near the end of the calibrated model simulation. Vertical hydraulic heads in the three layers representing the unconfined aquifer are almost identical throughout the simulation. Therefore, for comparison purposes between the unconfined aquifer and the upper confined aquifer, layers 2 and 11 were used, respectively in figure 13. During the summer stress period, simulated drawdowns caused by pumping can change the flow direction in some areas toward the pumping centers, particularly in the upper confined aquifer (fig. 13B). The effects of boundary conditions in layer 11 (upper confined aquifer) are visible under stressed conditions shown by curving of the potentiometric surface along the north and south model boundaries (fig. 13B). The effects of boundary conditions are more pronounced in the upper confined aquifer primarily because of lower hydraulic conductivity and storage values than the unconfined aquifer. However, these effects are considered negligible to results near most observation wells and the study PSW because of the distance from the boundary effects to most observation wells and the study PSW.

Early in the simulation time, hydraulic heads in the unconfined and upper confined aquifers were similar. Through time, with increasing withdrawals in the system, hydraulic heads generally decreased with depth, resulting in downward flow in most of the local-scale model area, consistent with head observations in well nests (Landon and others, 2007). Head measurements in the unconfined and upper confined aquifers early in the simulation period were insufficient to confirm whether the small or reversed vertical gradient early in the simulation period indicated by the model is historically accurate. However, the result is reasonable because the downward vertical head gradients are conceptually the result of withdrawals from irrigation from the upper confined aquifer.

Ground-water flow to the upper confined aquifer from the unconfined aquifer can be affected by abandoned wells, abandoned test holes, and drawdown constraints (see section "Boundary Conditions, Model Stresses, and Initial Conditions") on MNWs screened in the unconfined aquifer. Cumulative flow measurements collected from different depths in the study PSW (Landon and others, 2007) were compared to flow simulated by the MNW package. Simulated well-bore flow is consistent with measured well-bore flow for two measured profiles in the supply well, within the constraints of model discretization (fig. 14). Of the 329 multi-node wells in the model, flow (leakage) from the unconfined aquifer to one or both confined aquifers occurred in 72 wells, hereafter termed "leaky wells", in 2003 (fig. 15). Registered abandoned wells and known abandoned test holes comprise approximately 45 percent of the simulated leaky wells. Most simulated leaky wells are located in the northern and eastern portions of the model area. The locations of these leaky wells are related to the thickness of the upper confined aquifer, which thins in the southern and western portion of the local-scale model area. Therefore, because of lower well yields caused by thinning of the upper confined aquifer, few wells are screened below the unconfined aquifer in the southern and western portion of the local-scale model area. Drawdown constraints placed on MNWs that are screened in the unconfined aquifer restrict the amount of withdrawal from some wells (fig. 16). The majority of wells are pumped between 81 and 100 percent of the desired rate. Two wells are restricted to 33 to 40 percent of the total desired withdrawal rate. The restriction of withdrawal from a MNW may be related to the accuracy of the aquifer thickness, the accuracy of withdrawal and recharge estimates, or other uncertainties introduced by the representation of a physical system in a ground-water flow model. The occurrence of drawdown constraints is important because it has the effect of decreasing withdrawals from MNWs. With diminished withdrawals, lesser amounts of downward vertical leakage between layers may occur than if there were no drawdown constraints. However, transport simulations were not possible without drawdown constraints because dry cells were produced in some locations. Thus, drawdown constraints represent a source of uncertainty in estimating the volume of leakage down MNWs.

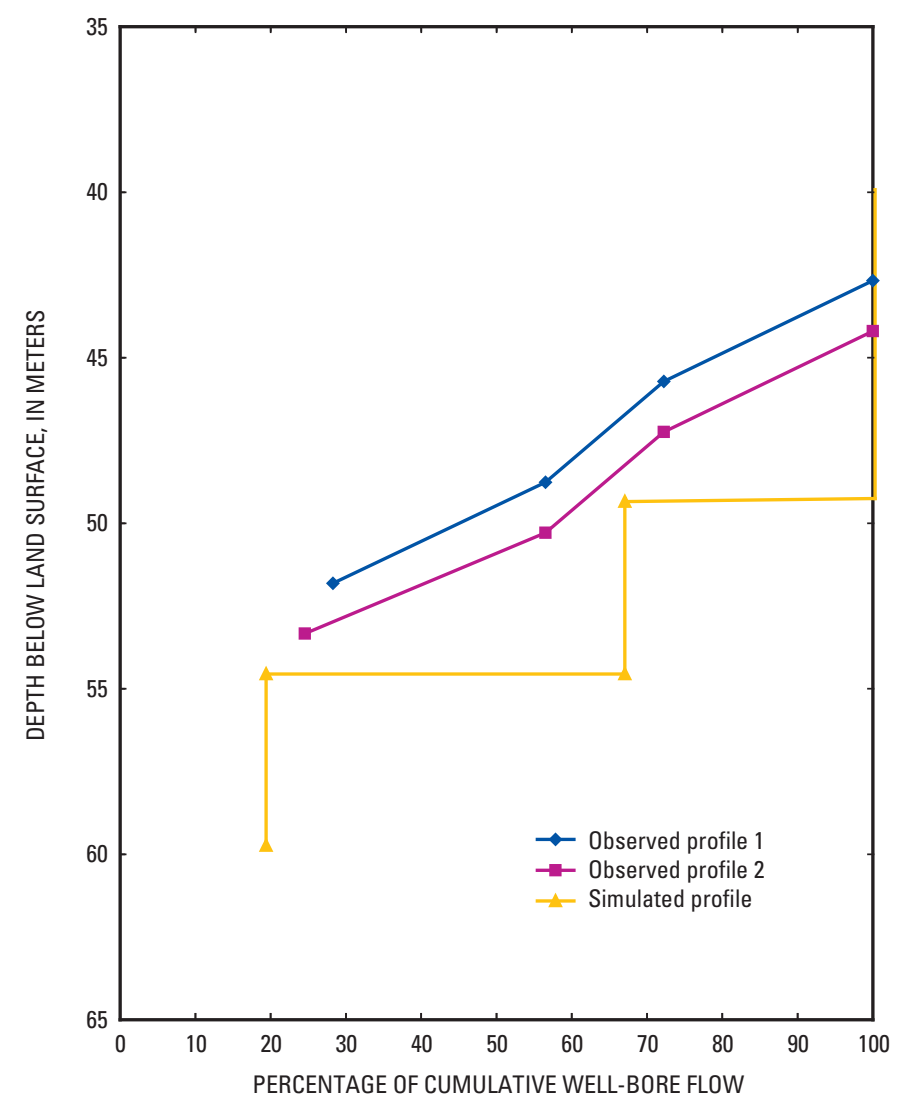

Figure 14. Simulated and observed flow measurements in the study public-supply well. 


\section{Simulated Water Budget}

The ground-water flow budget indicates changes in flow into (inflows) and out of (outflows) the model area during the pre-ground-water irrigation period to 2004 (fig. 17). Negative rates indicate outflows from the ground-water system, and positive rates indicate inflows to the ground-water system. Total flow (sum of inflows or outflows) through the model ranged from about $13,279 \mathrm{~m}^{3} / \mathrm{d}$ prior to development to $208,230 \mathrm{~m}^{3} / \mathrm{d}$ by the end of the simulation (summer 2004) (table 4).

Table 4. Ground-water budget comparison between predevelopment and summer, 2004.

\begin{tabular}{|c|c|c|c|}
\hline & Predevelopment & 2004 & \\
\hline Inflow & $\begin{array}{c}\text { Volumetric rate } \\
\text { (cubic meters } \\
\text { per day) }\end{array}$ & $\begin{array}{c}\text { Volumetric rate } \\
\text { (cubic meters } \\
\text { per day) }\end{array}$ & $\begin{array}{l}\text { Component } \\
\text { difference }\end{array}$ \\
\hline Storage & -- & 124,369 & 124,369 \\
\hline Flow head & 11,541 & 74,177 & 62,636 \\
\hline Drains & -- & -- & -- \\
\hline River & 0 & 433 & 433 \\
\hline Recharge & 1,738 & 9,251 & 7,513 \\
\hline $\begin{array}{l}\text { Multi-node } \\
\text { well }^{1}\end{array}$ & -- & -- & -- \\
\hline Total in & 13,279 & 208,230 & 194,951 \\
\hline Outflow & $\begin{array}{c}\text { Volumetric rate } \\
\text { (cubic meters } \\
\text { per day) }\end{array}$ & $\begin{array}{c}\text { Volumetric rate } \\
\text { (cubic meters } \\
\text { per day) }\end{array}$ & $\begin{array}{l}\text { Component } \\
\text { difference }\end{array}$ \\
\hline Storage & -- & 0 & 0 \\
\hline Flow head & 13,151 & 23,493 & 10,342 \\
\hline Drains & 0 & 0 & 0 \\
\hline River & 130 & 0 & -130 \\
\hline Recharge & -- & -- & -- \\
\hline $\begin{array}{l}\text { Multi-node } \\
\text { well }^{1}\end{array}$ & -- & 184,735 & 184,735 \\
\hline Total out & 13,281 & 208,228 & 194,947 \\
\hline
\end{tabular}

${ }^{1}$ Net outflow from multi-node well.

This increase in simulated flow through the model reflects increases in both withdrawals and recharge from the preground-water irrigation condition. There are four inflows to the model, listed from largest to smallest: areal recharge, removal from storage, flow-head boundary inflow, and river. There are five discharges or outflows, listed from largest to smallest: MNW (withdrawals from wells), addition to storage, flow-head boundary outflows, river, and drains. The MNWs represent the largest outflow components with a net rate of $184,735 \mathrm{~m} 3 / \mathrm{d}$ at the end of the model simulation in 2004. Ground-water outflows are offset primarily by inflow from aquifer storage and recharge. Inflows from constant head (boundary heads) mimic inflows from storage. As groundwater pumping removes water from storage, the decrease in hydraulic heads causes increased inflow from the boundaries.

\section{Simulated Transport and Particle-Tracking Results}

Simulated mean ages of water from six unconfined monitoring wells generally were similar to interpreted (mean apparent piston-flow) ages of the water. Simulated mean ages in unconfined wells were within 6 years of interpreted ages in five of the six wells (median error of 4 years), with interpreted ages ranging from 6 to 47 years and increasing with depth (fig. $19 \mathrm{~A}$, table 5). One well with a relatively large age residual of 16 years, OFPS-38, is influenced by the simulated river (Beaver Creek) in the local-scale model, which provides more young water to this monitoring well than must actually occur in the system. Simulated age could be younger than interpreted age in this well for several reasons: model discretization, high values of riverbed conductance, interpolation of river bottom elevation, and constant river stage values. In addition to OFPS-38, simulated age in four of the six wells were younger than interpreted ages. One reason for this may be related to the placement of abandoned wells or the screen length of wells in the unconfined aquifer, which allows younger water to travel to deeper portions of the unconfined aquifer faster than may naturally occur.

Table 5. Comparison of simulated and interpreted age simulations for water from wells screened in the unconfined aquifer.

[Simulated ages are from model layers corresponding to the screened interval for each well, age in years]

\begin{tabular}{cccccc}
\hline & & \multicolumn{5}{c}{$\begin{array}{c}\text { Simulated } \\
\text { age } \\
\text { without } \\
\text { Simulated } \\
\text { age } \\
\text { with } \\
\text { Well }\end{array}$} & $\begin{array}{c}\text { Inter- } \\
\text { preted } \\
\text { abandoned } \\
\text { wells } \\
\text { wells } \\
\text { (calibrated } \\
\text { name }\end{array}$ & $\begin{array}{c}\text { Simulated } \\
\text { (without } \\
\text { abandoned } \\
\text { well } \\
\text { model) }\end{array}$ & $\begin{array}{c}\text { wsing } \\
\text { well } \\
\text { model) }\end{array}$ & $\begin{array}{c}\text { Simulated } \\
\text { age using } \\
\text { steady } \\
\text { (well } \\
\text { state } \\
\text { model) }\end{array}$ & $\begin{array}{c}\text { (steady- } \\
\text { state } \\
\text { model) }\end{array}$ \\
\hline FP4-28 & 6 & 3 & 1 & 1 & 1 \\
FP3-83 & 47 & 42 & 25 & 18 & 22 \\
FP3-33 & 8 & 2 & 3 & 1 & 2 \\
FP4-83 & 43 & 40 & 33 & 24 & 21 \\
FP1-63 & 14 & 15 & 12 & 14 & 11 \\
OFPS-38 & 19 & 3 & 10 & 6 & 3 \\
\hline
\end{tabular}




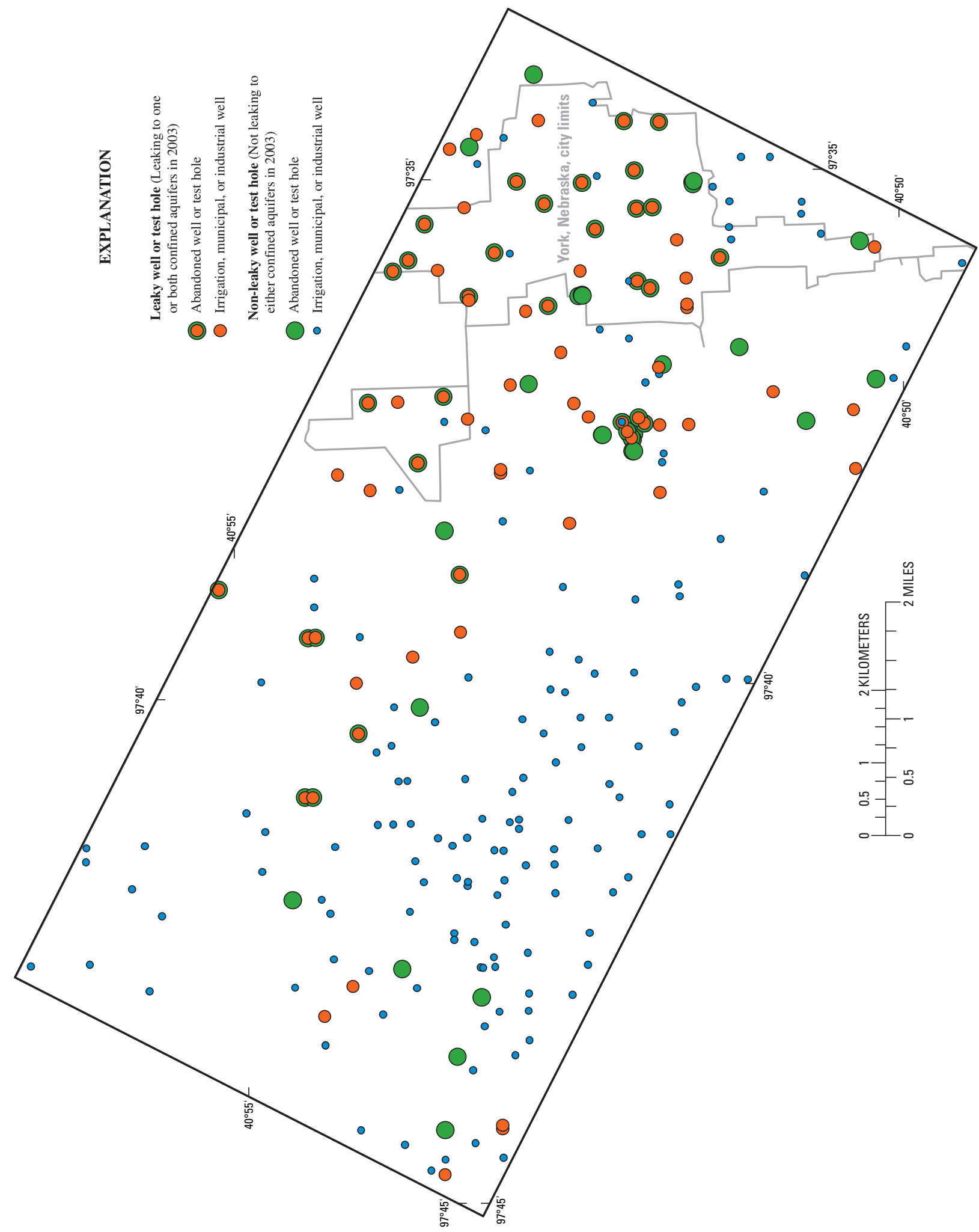

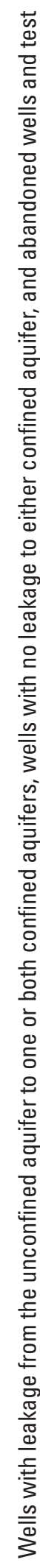




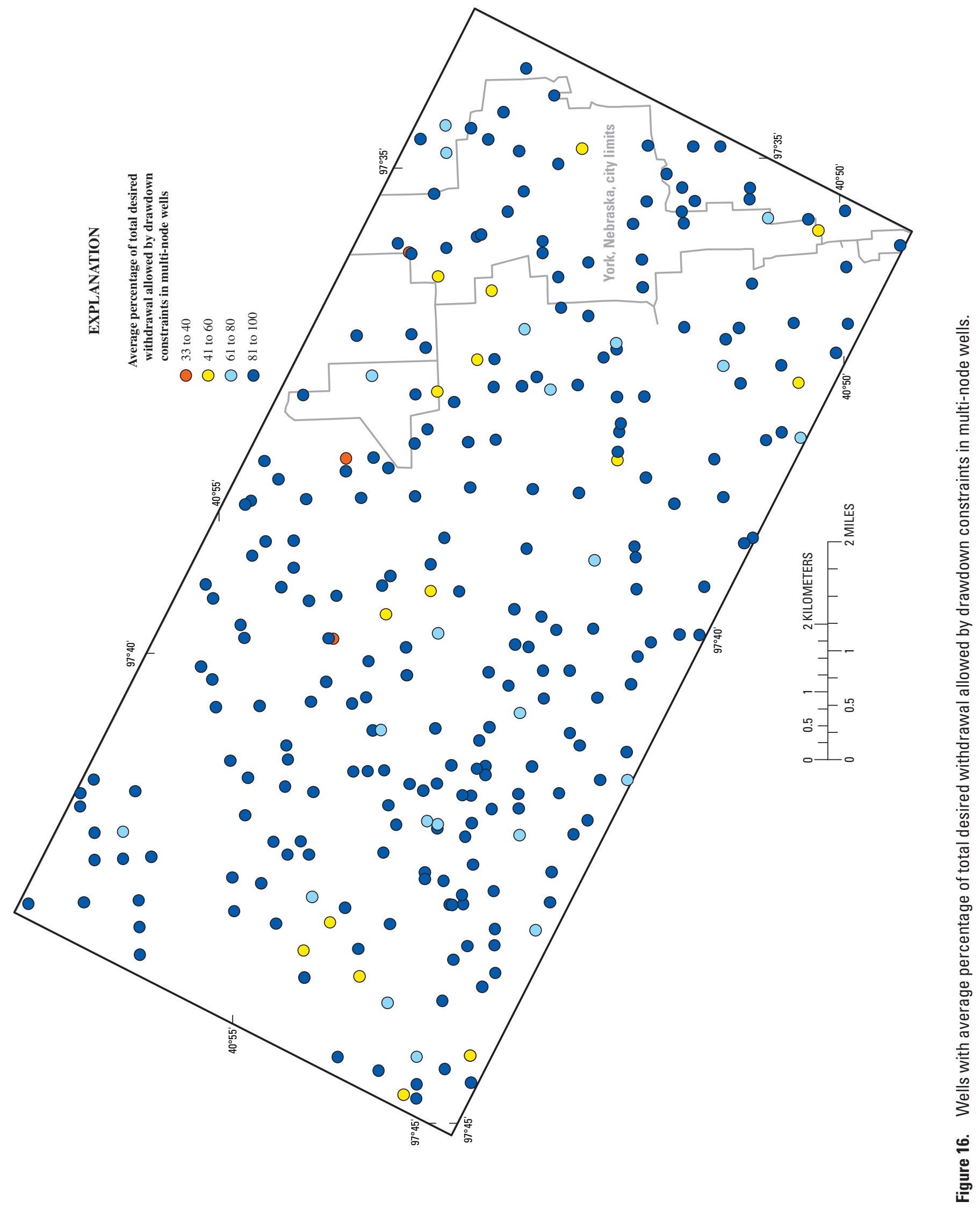




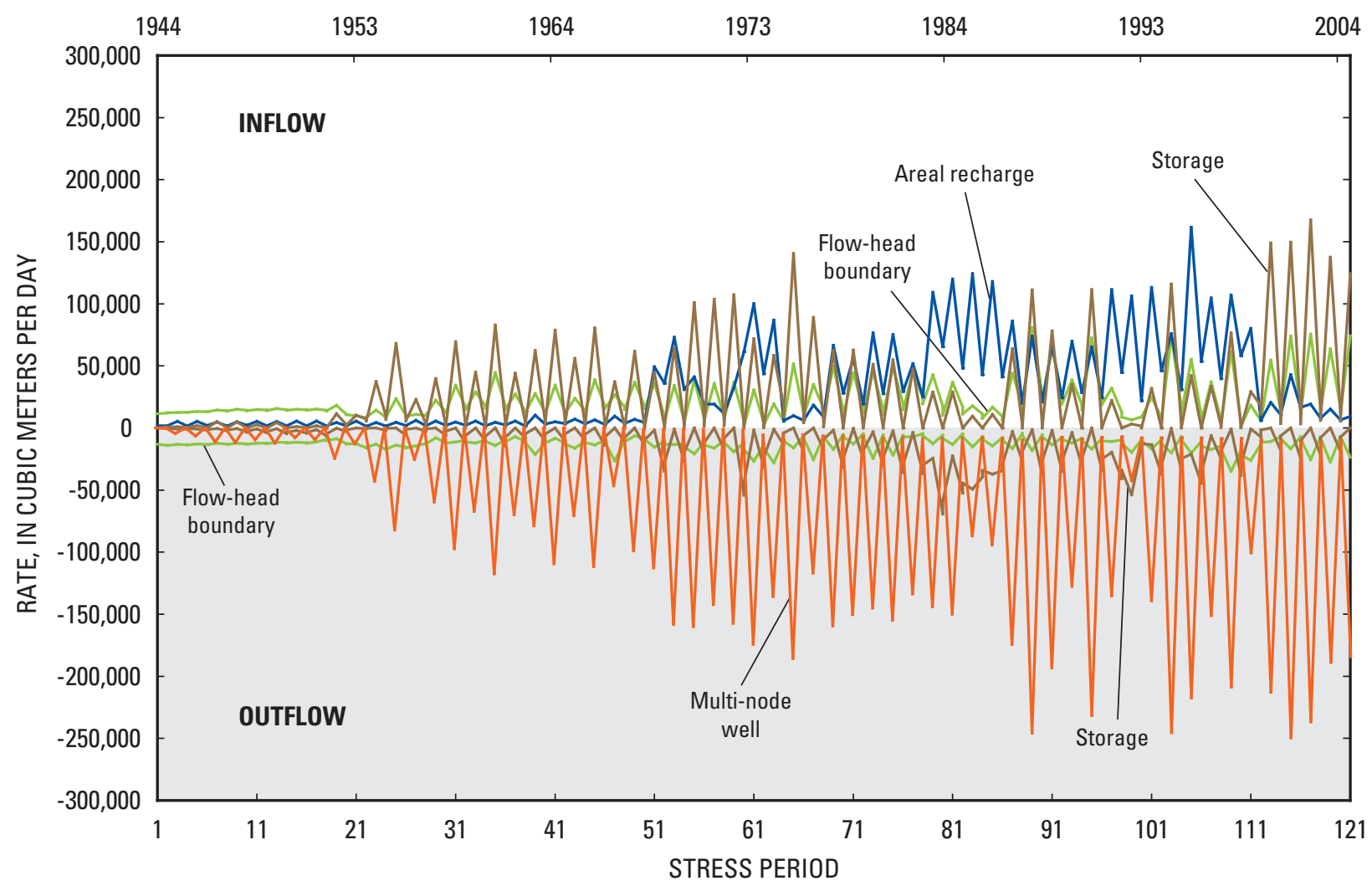

Figure 17. Components of the simulated water budget that have inflow or outflow exceeding 10,000 cubic meters per day. 
Simulated CFC-11 concentrations using the MNW package for wells in the upper confined aquifer showed considerable variability, similar to the variability of measured CFC-11 concentrations (table 6, fig. 19B). Simulated CFC-11 concentrations had a median residual of $0.06 \mathrm{pmol} / \mathrm{kg}$, a maximum residual of $0.92 \mathrm{pmol} / \mathrm{kg}$, and a minimum residual of -0.43 $\mathrm{pmol} / \mathrm{kg}$ over the range of measured CFC-11 concentrations ( 0.07 to $2.86 \mathrm{pmol} / \mathrm{kg}$ ) in the upper confined aquifer (table 4). Transport model simulations with GWT utilizing the MNW package indicated that particles with relatively younger ages and elevated CFC-11 concentrations were flowing down well bores into the upper confined aquifer (fig. 20). The similarity of simulated and measured CFC-11 concentrations was considered to be sufficient for the purpose of having a numerical model that could be used to understand the dynamics of the system and to evaluate the importance of well-bore leakage in influencing supply-well vulnerability.

The without abandoned well model demonstrated the importance of representing abandoned wells and test holes in simulations of ground-water age and CFC-11 concentrations. In two instances, at monitoring wells FP1-147 and FP4-168 (tables 2 and 6), a closer match of simulated and measured CFC-11 was obtained using the without abandoned well model than the calibrated model (table 4). Likewise, two age residuals, for monitoring wells FP3-33 and OFPS-38 (tables 2 and 5), were better in the without abandoned well model than in the calibrated model. The comparison of the calibrated and without abandoned well model results indicates that the distribution of young water in the upper confined aquifer is sensitive to the locations of leaky well bores, which are not known in reality. In the above cases where the residuals for the without abandoned well model are smaller, the results indicate the possibility of inaccurate locations of abandoned wells or test holes in the calibrated model. These results also could indicate that some abandoned wells and test holes simulated in the calibrated model do not provide the inter-layer well-bore flow as simulated. In fact, to accurately simulate the effects of abandoned or test wells, each well may need to differ in the Skin value assigned to it. This would require individual attention to each well, which was beyond the scope of this study.

Simulated age and CFC-11 from the well model generally did not compare with interpreted and measured values as well as the calibrated model. Simulated age in the upper and middle portion of the unconfined aquifer were generally within 7 years of the interpreted age (aside from possible river affects at OFPS-38); however, simulated ages near the bottom of the unconfined aquifer (FP3-83 and FP4-83) was substantially younger than interpreted age. Simulated CFC-11 concentrations in the upper confined aquifer were lower than measured using the well model. These results indicate that even with adjustments in vertical anisotropy allowing more matrix flow through the confining unit, the well model did not permit rapid enough flow through the confining unit to match measured CFC values in the upper confined aquifer. In addition, the decreased vertical anisotropy resulted in younger simulated ages in the lower portion of the unconfined aquifer than intepreted (table 5). These results support the interpretation that the calibrated model, including leaky well bores, is a better representation of the system.

Table 6. Comparison of simulated and measured CFC-11 concentrations for water from wells screened in the upper confined aquifer.

[Simulated concentrations are from model layers corresponding to the screened interval for each well. CFC-11 concentrations in picomole per kilogram]

\begin{tabular}{|c|c|c|c|c|c|}
\hline $\begin{array}{l}\text { Well } \\
\text { name }\end{array}$ & $\begin{array}{c}\text { Measured } \\
\text { CFC-11 }\end{array}$ & $\begin{array}{c}\text { Simulated } \\
\text { CFC-11 with } \\
\text { abandoned } \\
\text { wells } \\
\text { (calibrated } \\
\text { model) }\end{array}$ & $\begin{array}{l}\text { Simulated } \\
\text { CFC-11 without } \\
\text { abandoned } \\
\text { wells } \\
\text { (without } \\
\text { abandoned } \\
\text { well model) }\end{array}$ & $\begin{array}{c}\text { Simulated } \\
\text { CFC-11 using } \\
\text { well package } \\
\text { (well model) }\end{array}$ & $\begin{array}{c}\text { Simulated } \\
\text { CFC-11 using } \\
\text { steady state } \\
\text { (steady-state } \\
\text { model) }\end{array}$ \\
\hline FP1-147 & 0.09 & $2.10 \mathrm{E}-26$ & 4.73E-03 & 0 & 0.09 \\
\hline FP1-185 & 0.07 & 0.01 & 4.39E-06 & 0 & 0.30 \\
\hline FP3-130 & 0.36 & 0.54 & 1.84 & 0 & 1.03 \\
\hline FP3-162 & 2.86 & 3.78 & 4.37 & 0 & 3.93 \\
\hline $77-4$ & 0.69 & 0.26 & $1.89 \mathrm{E}-03$ & 0.0225721 & 0.36 \\
\hline FP4-168 & 0.10 & 0.68 & 0.25 & 0 & 0.57 \\
\hline
\end{tabular}

\footnotetext{
${ }^{1}$ CFC-11 concentration from layer 11, which PSW 77-4 is screened through.
} 


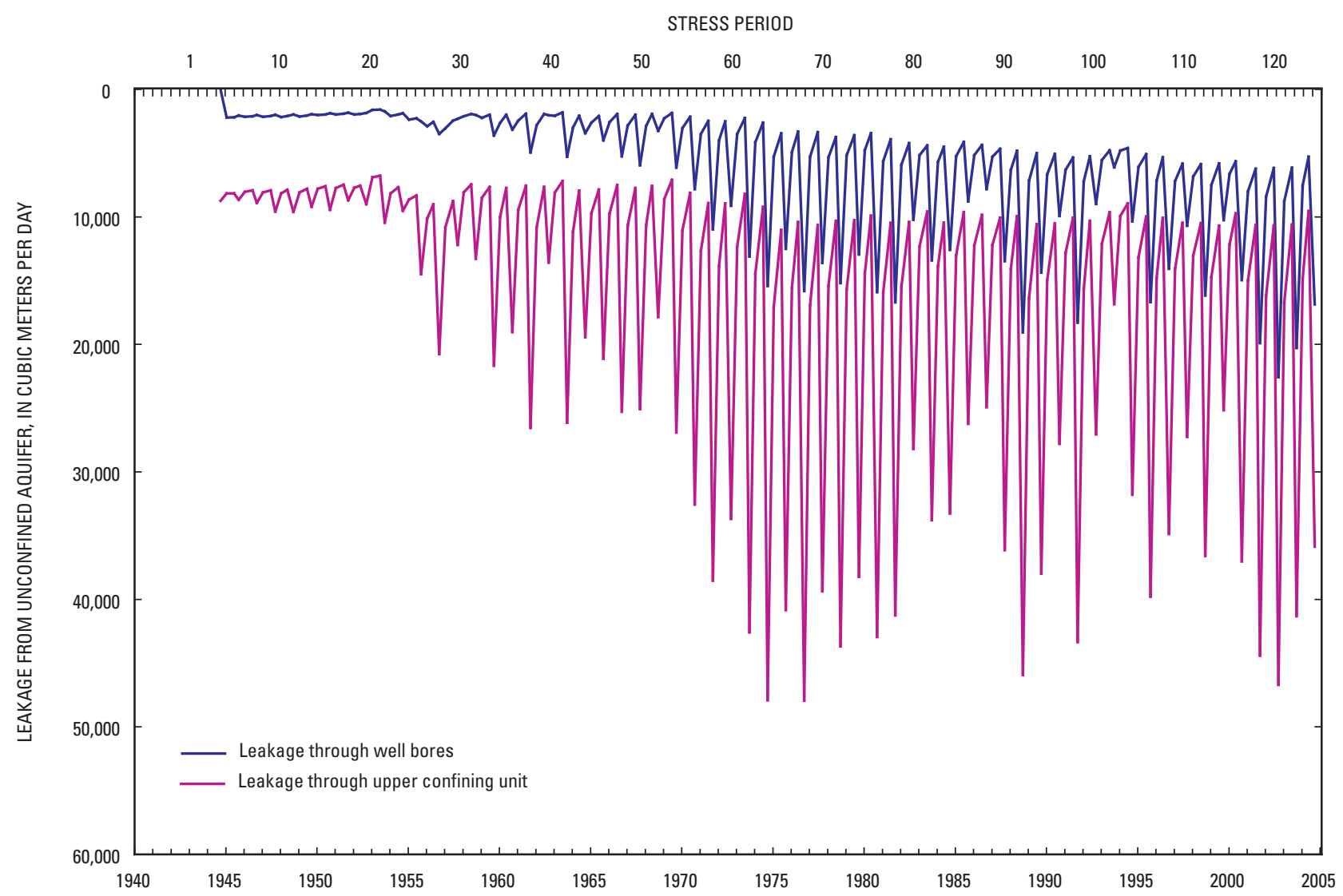

Figure 18. Simulated leakage through well bores and leakage through the upper confining unit.
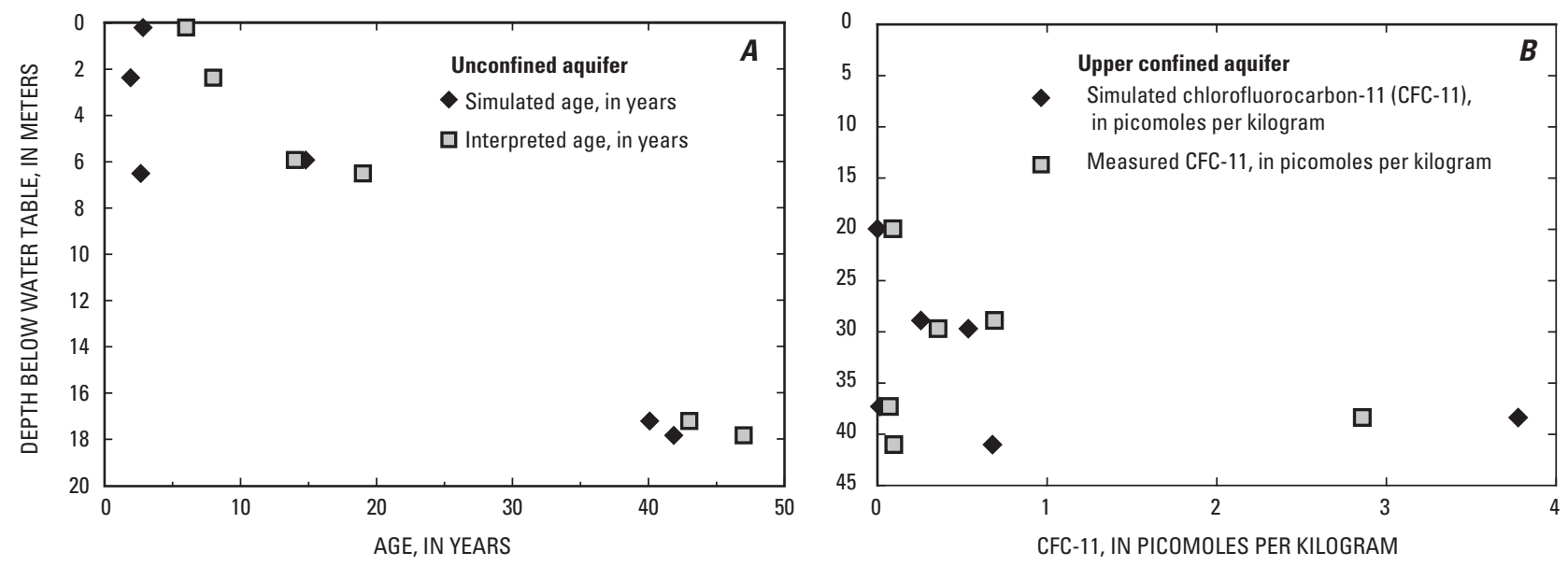

Figure 19. Comparison of simulated and interpreted age (A) and measured CFC-11 concentrations (B) for six selected wells. 
The steady-state model produced a fit of simulated and measured age and CFC-11 concentrations comparable to the calibrated model (tables 5 and 6). However, the steady-state model had higher mean absolute values of head residuals than the calibrated model for the time period of 1997-2001. This was to be expected because all hydraulic parameters were calibrated for a transient simulation.

\section{Contributing Recharge Area Summary}

Particle tracking was implemented on output from the steady-state model to represent the contributing recharge area of the study PSW (fig. 21). The total contributing recharge area captured by the study PSW is approximately $6.3 \mathrm{~km}^{2}$, with a mean traveltime of 230 years (table 5). Urban area makes up the largest percentage (45 percent) of the contributing recharge area, followed by agricultural area (39 percent) (table 7). The steady-state model contributing area differs from that of the regional-scale model (Landon and Turco, 2007) by including particles originating from the east boundary of the local-scale model area and a shorter contributing recharge area that does not extend to the west side of the local-scale model area. These differences are attributed primarily to the use of the MNW package, allowing flow between layers through well bores and the use of specified heads rather than specified fluxes at the eastern and western boundaries. Irregular shapes, such as the isolated area to the west of the primary contribut- ing recharge area, are a consequence of contributing recharge areas of MNWs. A percentage of recharge water to the MNWs flows through the respective well bore of the MNW, into the upper confined aquifer and then to the supply well (fig. 21). Most of the supply well contributing recharge area reflects the movement of water from the unconfined to the upper confined aquifer through MNWs (fig. 21). The contribution to the supply well contributing recharge area from water moving through the matrix of the upper confining unit is shown in yellow on figure 21 and generally is located closer to the study PSW than that part of the contributing area because of MNW flow.

\section{Comparison of Simulated Transport and Particle Tracking Age Distribution}

Though an estimate of mean age for a well where mixing is limited may be useful, knowledge of the distribution of particles of differing ages is necessary to understand the processes and mechanisms contributing to a well where mixing occurs. For this reason, the distribution of ages was compiled from the steady-state model MODPATH simulation. Simulated particles were grouped into bins that represented 1-year intervals. Because each particle was associated with a flow volume (as previously discussed in the 'Design of Particle Tracking Simulations' section), the total volume of flow into the study PSW

Table 7. The study public-supply well information and contributing recharge area summary statistics.

Land surface altitude

(meters above NGVD of 1929)

490.50

Depth to top of

screened interval

(meters)

Depth to bottom of

screened interval

(meters)

60.05

Casing diameter

(centimeters)

40.6

Contributing

recharge area

(square kilometers)

Area of zone

of contribution

(square kilometers)

Volume of zone

of contribution

(cubic kilometers)
Minimum travel time

(years)

4

Maximum travel time

(years)

Mean travel time

(years)

Percent of contributing recharge area from urban areas

Percent of contributing recharge area from agricultural areas

Percent of contributing recharge area from forested areas

11

Percent of contributing recharge area from rangeland
4 

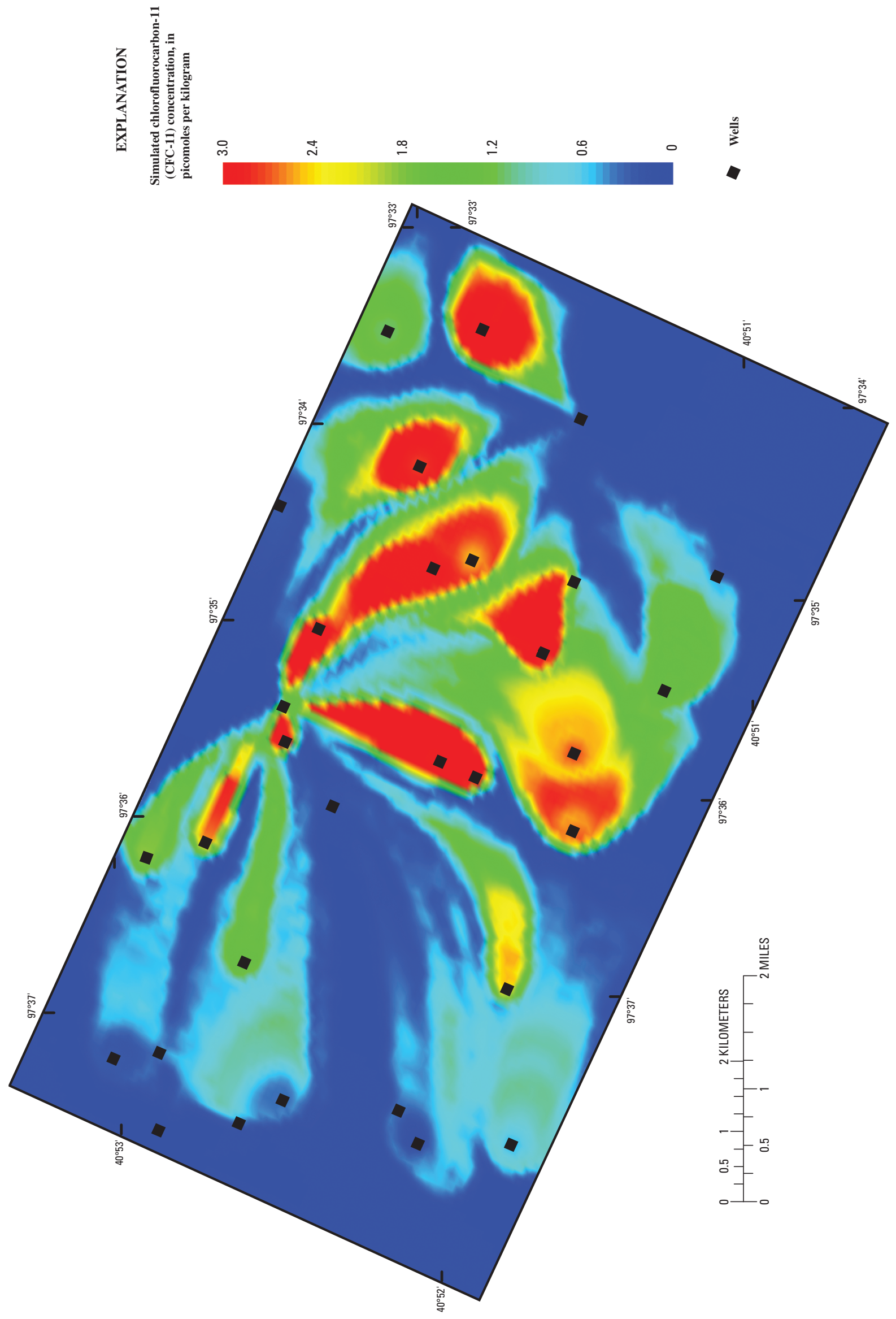

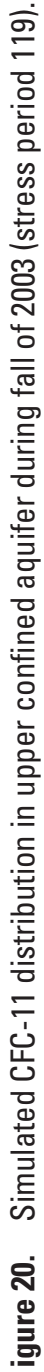




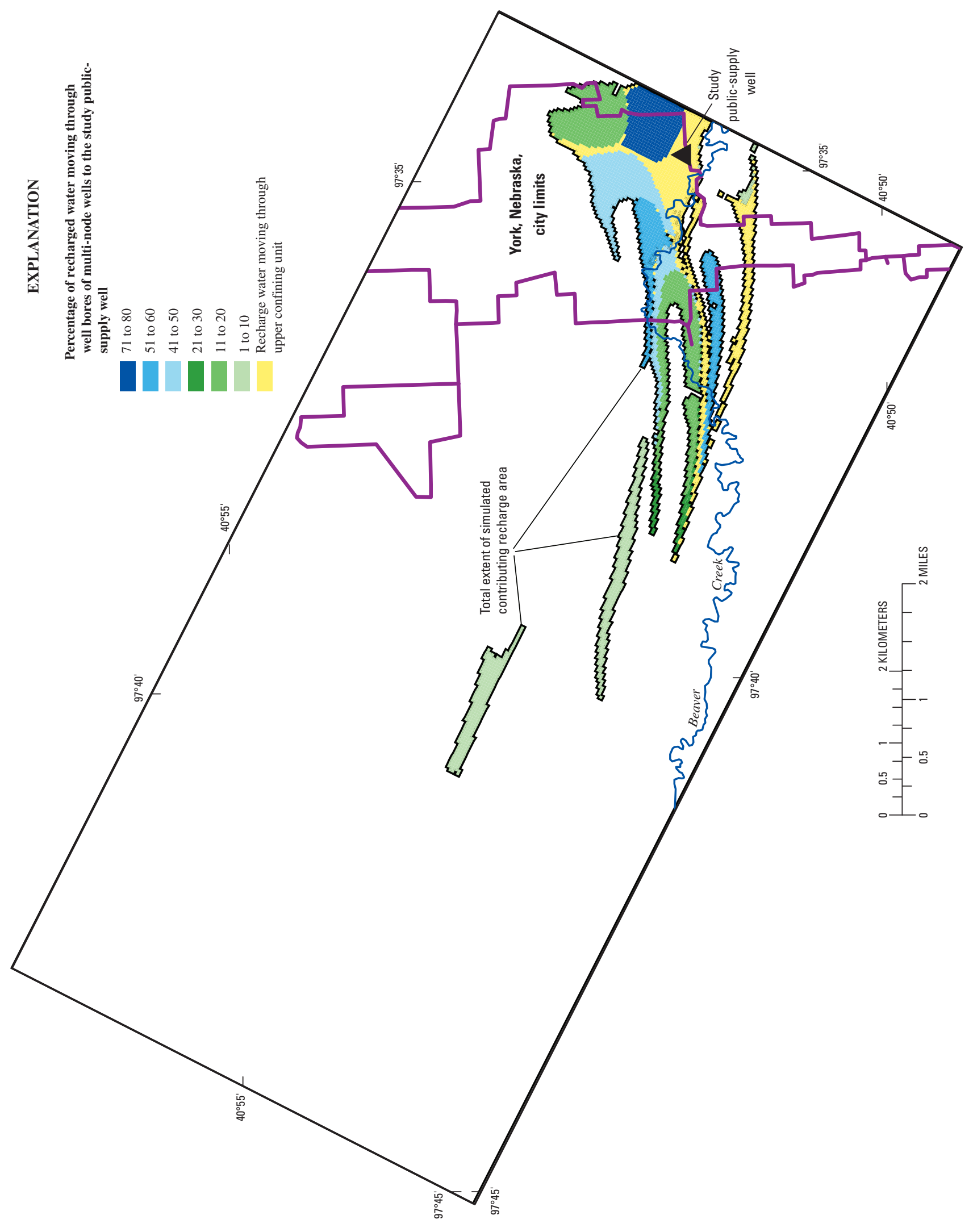

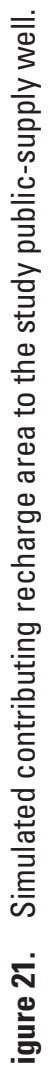


associated with each age bin could be summed. GWT simulations of the calibrated and steady-state model also provide a distribution of volume-weighted ages for all particles entering a specific model cell or MNW.

All three of the simulations indicate an age distribution in the study PSW that compares reasonably well with the age distribution interpreted from a lumped-parameter exponential binary mixing model for sulfur hexafluoride (SF6) and CFC-11 data (Landon and others, 2007), considering many sources of uncertainty in interpreted and simulated results (fig. 22). Interpretations of age tracer and stable isotope data for the study PSW indicate samples from the wellhead are a mixture of 7 percent water with a mean age of 9 years (using SF6) to 14 percent water with a mean age of 14 years (using CFC-11) mixed with 86 to 93 percent old, upper confined aquifer water (Landon and others, 2007). These percentages are approximately consistent with 12 percent unconfined aquifer water mixed with 88 percent upper confined aquifer water based on hydrogen isotope $(\delta \mathrm{D})$ values. The $\delta \mathrm{D}$ values indicate the percent of young water derived from the unconfined aquifer but do not indicate a specific age of the water. However, the contrast in unconfined $\delta \mathrm{D}$ water are interpreted to result from changes in land use and recharge processes during the last approximately 40 years (Landon and others, 2007), providing an age range and percent for comparison with other interpreted tracer and simulated values. This $\delta \mathrm{D}$ percent and likely age range compare reasonably well with the simulated age distribution of the steady-state model using GWT and the steadystate model using MODPATH. From the age distribution of the steady-state model using MODPATH, the youngest 7 percent of the water (corresponding with the percent from interpreted SF6 data) would have a weighted mean age of 16 years, while the youngest 14 percent of the water (corresponding with the percent from interpreted CFC-11 data) would have a weighted mean age of 21 years (fig. 22). Comparison of simulated and interpreted young water percentages and mean ages imply that the simulations predict young percentages that are smaller or mean ages that are older than those interpreted from age tracer data. However, the age tracer interpretations for SF6 and CFC-11 are based on assumptions of a simple binary mixing of exponentially mixed unconfined water and old upper confined water and constant age distributions through time (Landon and others, 2007). Therefore, the age tracer interpretations of SF6 and CFC-11 may not accurately reflect the true complexity of the ground-water system dynamics and do not represent a better estimate than simulated ages. Because both the age tracer interpretations and simulations have uncertainties, the ranges of young water percentages and mean ages

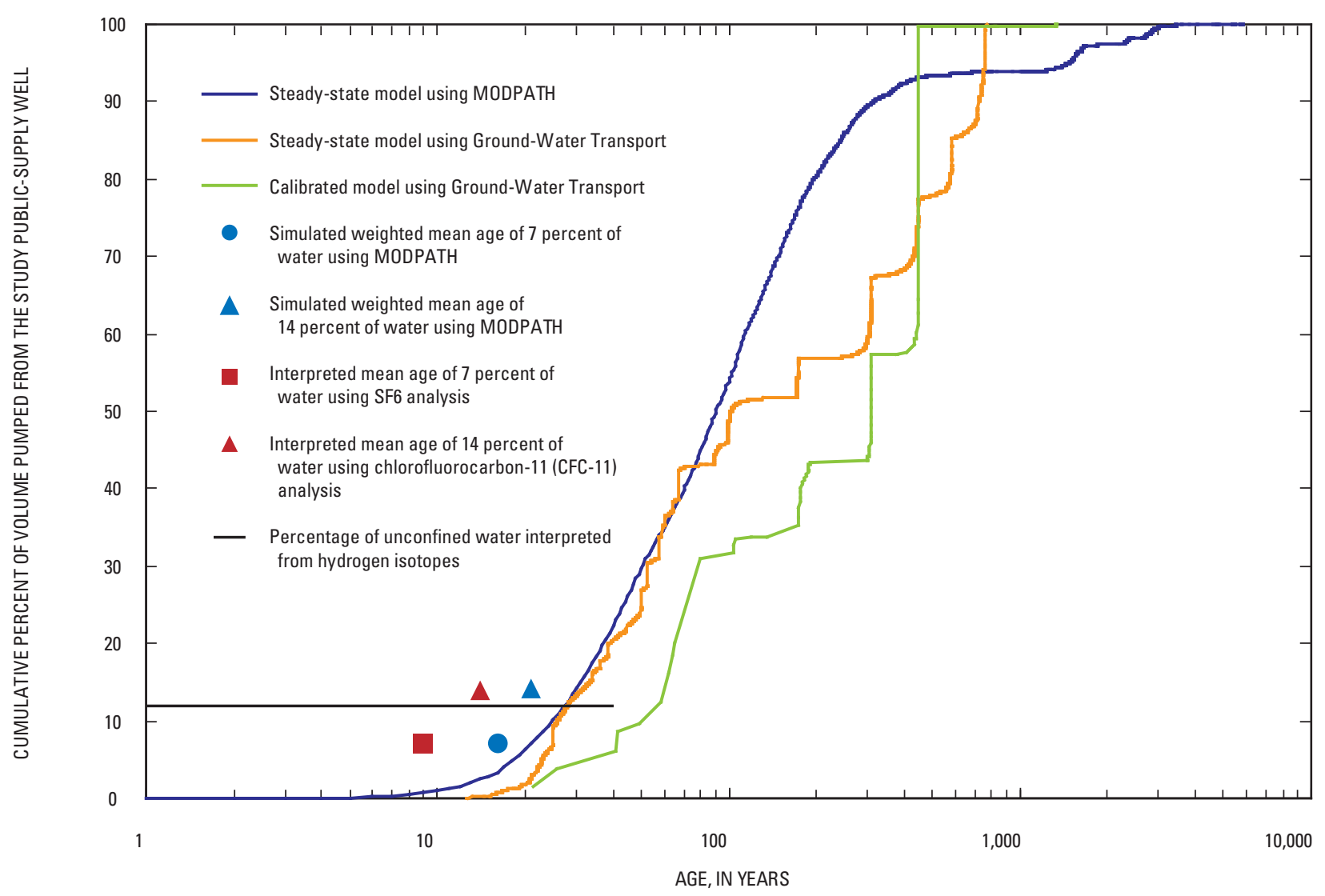

Figure 22. Age distribution comparisons of the steady-state model using MODPATH, steady-state model using Ground-Water Transport, and calibrated model using Ground-Water Transport for the study public-supply well. 
using the different methods can be used to bracket a general range of likely results. All of the methods discussed indicate a relatively small percentage ( 7 to 14 percent) of young water having a mean age in the range of 9 to 21 years.

The age distribution of the steady-state model using MODPATH indicates all water younger than 58 years travels through well bores of MNWs, while water older than 58 years travels primarily through the upper confining unit (fig. 23). The age distribution of the calibrated model using GWT estimates the youngest 10 percent of the water to be about 49 years or less. The differences between the calibrated model using GWT and the steady-state and MODPATH distributions may be attributed to the number of particles captured by the study PSW at a specific time, which differs based on the transient flow field. The calibrated model using GWT captures 94 particles while the steady-state model with GWT captures 2,830 particles. This indicates that larger volumes of water are represented by fewer particles in the transient simulation, thus the age of a percentage of water volume may be skewed older or younger by a few particles. This also helps to explain the larger vertical stairstep effect of the calibrated model curve when compared to the relatively smaller vertical stairstep effect of the steady-state model using GWT on figure 22.

\section{Long-Term Concentrations of Nitrate in the Study Public-Supply Well}

Long-term projections for nitrate (as nitrogen, hereafter referred to as nitrate-N) concentrations were examined to explore the effects of denitrification on future nitrate- $\mathrm{N}$ concentrations. Projected nitrate- $\mathrm{N}$ concentrations at the study PSW were calculated by applying estimated concentrations of nitrate-N to particles from forward-tracking MODPATH results of the steady-state model. Estimated nitrate-N concentrations assume a constant proportion of about 45 percent urban land, 39 percent agricultural land, 11 percent forested land, and 4 percent rangeland. Isotopic and geochemical data (Landon and others, 2007) indicate that nitrate concentrations were derived from fertilizer application and from septic system sources in urban areas. Livestock waste may have important effects on ground-water quality in local areas (Landon and others, 2007). Nitrate-N was projected into the future to be 15 $\mathrm{mg} / \mathrm{L}$ in recharge water beneath agricultural areas. The projected nitrate- $\mathrm{N}$ value was the median nitrate- $\mathrm{N}$ after correction for denitrification in agricultural waters (sampling period October 2003 through April 2005, apparent recharge date of ground water sampled, 1979-2000) (McMahon, in press; McMahon and others, 1999). Nitrate-N derived from septic

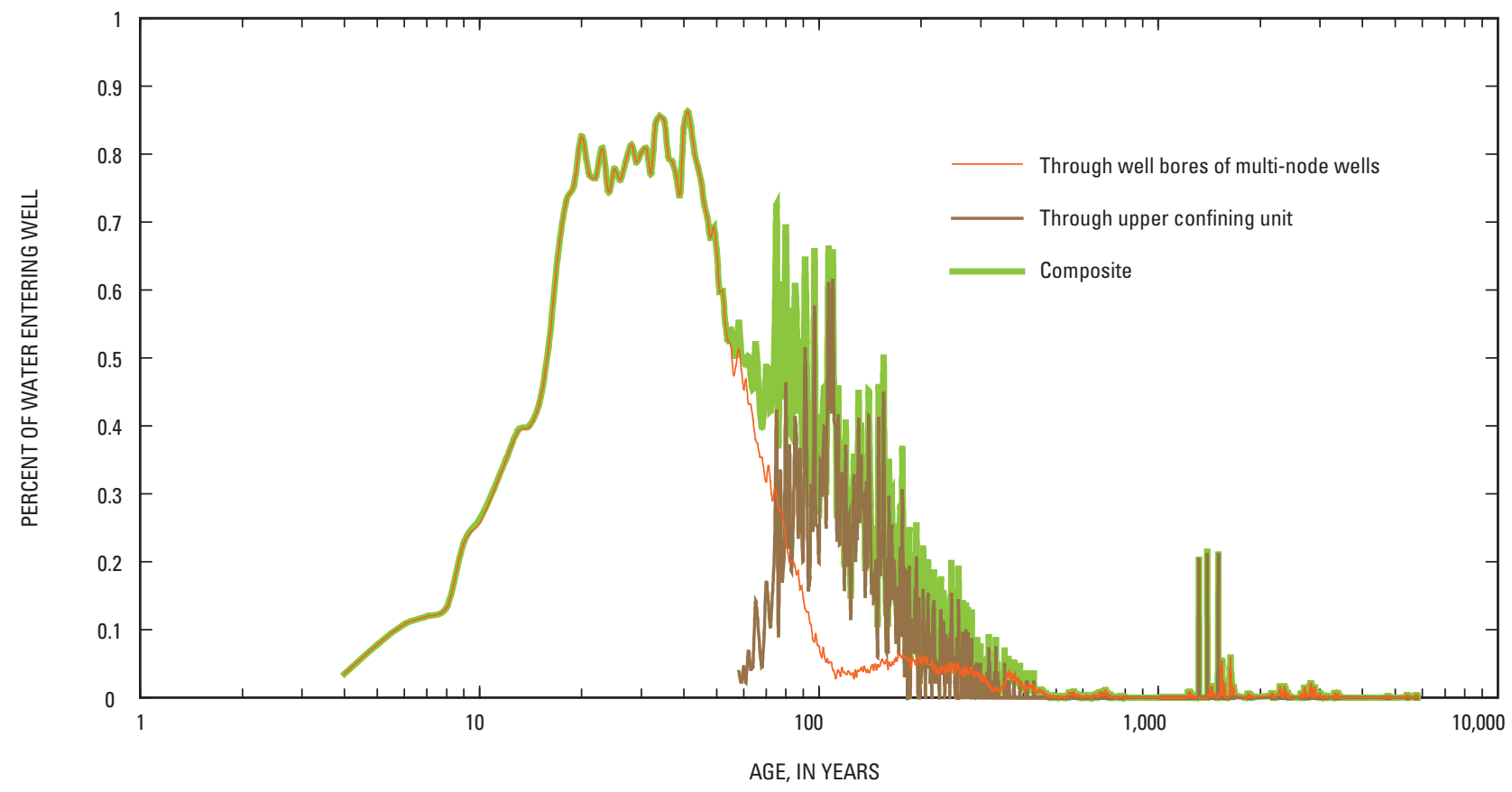

Figure 23. Age distribution simulated by steady-state model using MODPATH by percent of water entering the study public-supply well through well bores, the upper confining unit, and a composite of both. 
sources in urban recharge waters was estimated to increase linearly from 1945 to 2000 from $2 \mathrm{mg} / \mathrm{L}$ to $22.5 \mathrm{mg} / \mathrm{L}$, and maintain a constant concentration of $22.5 \mathrm{mg} / \mathrm{L}$ in the future. A linear increase was assumed because of population increase and increasing availability of septic system technology. The concentration of $22.5 \mathrm{mg} / \mathrm{L}$ was the median nitrate- $\mathrm{N}$, after correction for denitrification, in urban waters (Landon and others, 2007). The concentration of nitrate over rangeland and forested areas was held constant at $2 \mathrm{mg} / \mathrm{L}$ beginning in 1945 . No changes in land use in the contributing recharge areas were considered. The calculations presented are simplistic and are not meant to address the effects of changes in future land use. The calculations are to illustrate simple scenarios only, but provide a hypothetical tool to investigate the effects of other possible changes. A background nitrate- $\mathrm{N}$ concentration of 2 $\mathrm{mg} / \mathrm{L}$ was assumed prior to 1945 (Landon and others, 2007). A first order reaction coefficient of 0.3 year- 1 was used to simulate decay of nitrate- $\mathrm{N}$ concentrations in the upper confining unit and upper confined aquifer; this value was based upon denitrification rates in the upper confining unit determined from fitting advective-dispersive-reactive transport models to chemical and isotopic profiles of pore water (McMahon, in press; McMahon and others, 1999). The calculated concentration of nitrate-N of $0.19 \mathrm{mg} / \mathrm{L}$ for 2003 of the forward projection compares well to measured values of nitrate- $\mathrm{N}$ at the study PSW which range from 0.17 to $0.20 \mathrm{mg} / \mathrm{L}$. With the assumptions discussed above, the projections indicate that nitrate- $\mathrm{N}$ concentrations reached values of about $0.19 \mathrm{mg} / \mathrm{L}$ by 2000 and will remain near this value for the next 100 years (fig. 24). This result is controlled by the denitrification rate. The peak value of decayed nitrate- $\mathrm{N}$ appears to lag behind the input concentration in recharge by approximately 30 years. If electron donors such as organic carbon or reduced sulfide minerals were depleted with ongoing denitrification, the decay rate could decrease and nitrate-N concentrations would increase.

For comparison, projection calculations assuming that denitrification does not occur in the upper confining unit and upper confining aquifer (decay rate equal to zero) indicated concentrations of nitrate-N in the study PSW of $6.4 \mathrm{mg} / \mathrm{L}$ in 2003 and $12.3 \mathrm{mg} / \mathrm{L}$ after 100 years (fig. 24). For the case without denitrification, nitrate concentrations largely are controlled by mixing of high nitrate shallow recharge waters with water from the upper confined aquifer that was recharged with low nitrate concentrations prior to modern agricultural and urban influences. The non-decayed concentration of nitrate- $\mathrm{N}$ does not appear to reach a peak value by 2110 , but continues to rise. This indicates a lag time of over 100 years behind the input concentration in recharge. Although the forward projections are based upon simplifying assumptions, they can be used to explore some of the sensitivity of future nitrate- $\mathrm{N}$ concentrations to different future land-use scenarios.

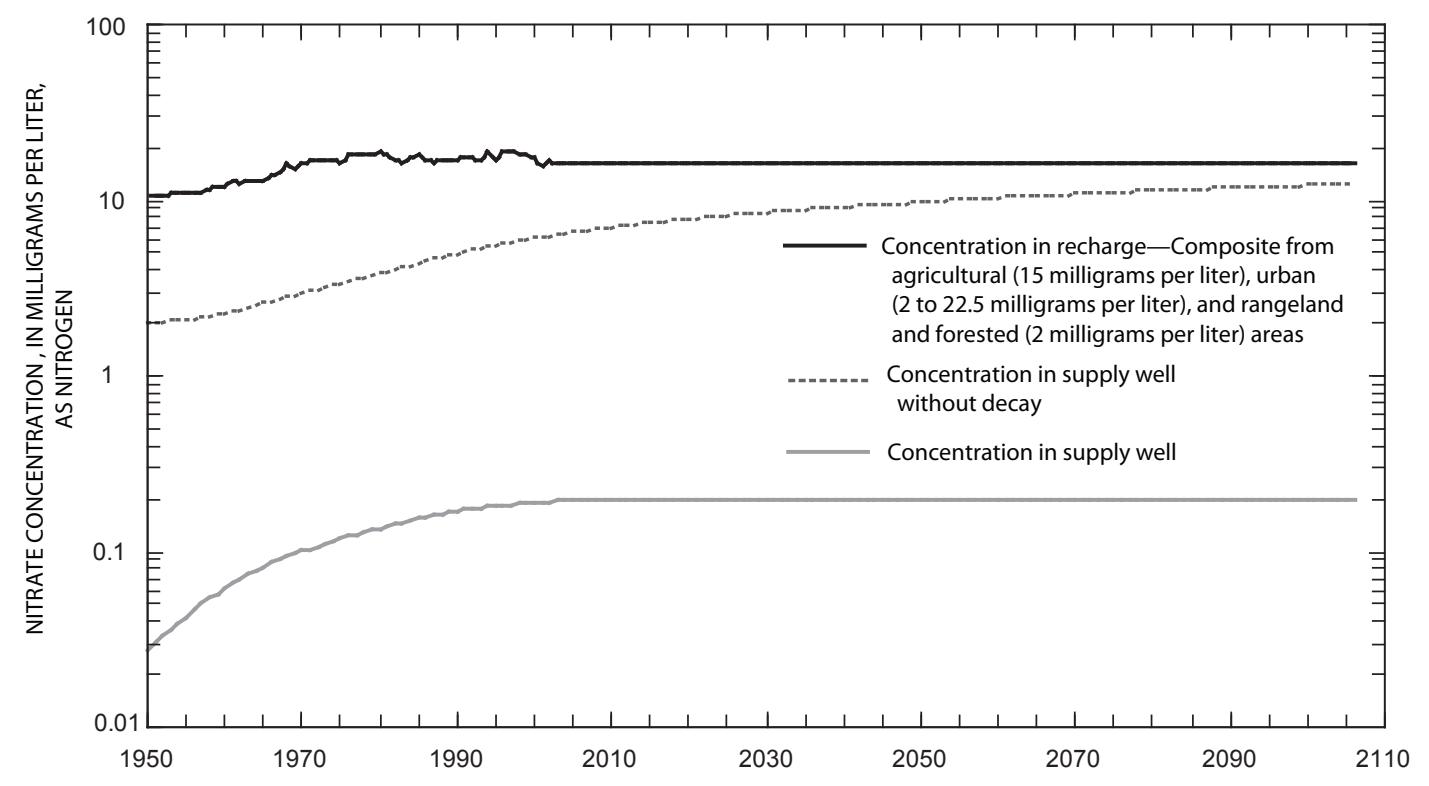

Figure 24. Simulated long-term nitrate-N concentration at the study public-supply well. 


\section{Implications of Well-Bore Leakage on Ground-Water Quality}

One of the major issues affecting ground-water quality used for public supply in the local-scale model area is the fact that young, sometimes contaminated, water finds its way into the upper confined aquifer. One early hypothesis for this water movement was attributed to leakage of water through the upper confining unit through some preferential flow paths such as cracks or voids in the clay. The refined hypothesis for this water movement is that wells screened through multiple aquifers provide flow paths through the well bore itself, thus providing a "short circuit" through the upper confining unit into the upper confined aquifer (fig. 2). This hypothesis was proposed because of lack of data to indicate cracks or voids in the upper confining unit, the fact that there are numerous wells in the local-scale model area screened through multiple aquifers, and the large downward head gradients across the upper confining unit (conditions that would lead to downward flow through well bores). The occurrence of relatively young water having unconfined aquifer geochemical signatures in the study PSW and a few monitoring wells that were screened in the upper confined aquifer, but the absence of such signatures in most monitoring wells screened in the upper confined aquifer, is consistent with unconfined waters moving into the upper confined aquifer in a few places along preferential flow paths (Landon and others, 2007). The most likely preferential flow paths are well-bores crossing the upper confining unit. While source-area contaminant loading rates and reactions affect contaminant movement, the model simulations described in this report support the hypothesis that vertical leakage of water down multilayer well bores is a controlling process influencing the transport of young waters to PSW. This is demonstrated in animations of CFC-11 transport of the calibrated model, the abandoned model, and the steady-state model, included in appendix 2 of this report. An explanation of software used and a description of each animation is included in appendix 2 .

\section{Summary and Conclusions}

Concerns about contamination of public supply wells have lead to widespread interest in understanding the vulnerability of public supply wells to contamination. To investigate factors controlling vulnerability of PSW to anthropogenic and natural contaminants using consistent and systematic data collected in a variety of principal aquifer settings in the United States, a study of TANC to public supply wells was begun in 2001 as part of the USGS NAWQA Program.

The area simulated by the ground-water flow model described in this report is rectangular in shape and covers 108.4 square kilometers. A study of processes influencing contaminant distribution and transport along the direction of ground-water flow towards a PSW in southeastern York, Nebraska. This local-scale model is nested within a regionalscale model of 388.5 square kilometers. Ground-water flow in the High Plains aquifer in the local-scale model is simulated for a 60-year period from September 1, 1944, to August 31, 2004. Steady-state conditions are simulated prior to September 1,1944 , and represent conditions prior to use of ground water for irrigation.

Because of large downward hydraulic head gradients between unconfined and confined aquifers and the common practice of screening production wells in multiple aquifers, it was suspected that movement of young water susceptible to anthropogenic contamination in the unconfined aquifer down well bores crossing confining units could have an influence on water quality in the confined aquifers where PSW are screened. Irrigation, municipal, and industrial wells were simulated using the MNW package of the modular three-dimensional ground-water flow model code, MODFLOW-2000, which allows simulation of flow and solutes through wells that are simulated in multiple nodes, or layers. Ground-water flow, age, and transport of selected tracers were simulated using the GWT process for MODFLOW-2000. Simulated groundwater age was compared to interpreted ground-water age in six monitoring wells in the unconfined aquifer. In the upper confined aquifer, mixing of younger water from the unconfined aquifer and older water from the upper confined aquifer was evaluated by simulating the concentration of a specific age tracer rather than ground-water age. The tracer CFC-11 was simulated directly using GWT for comparison with concentrations measured in six monitoring wells and one public supply well screened in the upper confined aquifer.

In addition to flow and transport simulations under transient conditions with multi-node pumping wells (hereafter referred to as the calibrated model), three alternative models were constructed to examine the effects of alternative conceptualizations of the physical system on simulation results. The first of the three alternative models was identical to the calibrated model except that all registered abandoned wells and test holes were excluded from the simulation to test the sensitivity of the simulations to multilayer leakage in these inactive well bores. The second alternative model used the conventional Well Package of MODFLOW-2000, which does not simulate flow between model layers through well bores, in place of the MNW package. The third alternative model was identical to the calibrated model except that is was constructed as a steady-state simulation representing 1997-2001 conditions to examine the differences and importance of simulating transient conditions.

The alternative model simulations indicate that simulation results are highly sensitive to the distribution of multilayer well bores where leakage can occur and that the calibrated model resulted in smaller differences than the alternative models between simulated and interpreted ages and measured tracer concentrations in most, but not all, wells. Results of the first alternative model indicate that the distribution of young water in the upper confined aquifer is substantially different 
when well-bore leakage at known abandoned wells and test holes is removed from the model. The distribution of young water is sensitive to the location of leaky well bores, which are not known in reality. The second alternative model generally did not compare with measured tracer concentrations as well as the calibrated model. In the second alternative model, simulated age near the bottom of the unconfined aquifer was younger than interpreted ages and simulated CFC-11 concentrations in the upper confined aquifer were lower than measured values. The third alternative model produced differences between simulated and interpreted ground-water ages and measured CFC-11 concentrations that were comparable to the calibrated model. However, simulated hydraulic heads deviated from measured hydraulic heads by a greater amount than for the calibrated model. Even so, because the third alternative model simulates steady-state flow, additional analysis was possible using steady-state particle tracking to examine the contributing recharge area to the study PSW selected for analysis of factors contributing to well vulnerability.

Particle tracking using the steady-state model indicates that the contributing recharge areas of public supply wells in this setting are composites of elongated, seemingly isolated areas associated with wells that are screened in multiple aquifers. Water captured by these wells flows downward through their well bores, into the upper confined aquifer, and towards the discharging production wells screened in the upper confined aquifer. The simulated age distribution of particles at the study PSW indicate that all water younger than 58 years travel through well bores of wells screened in multiple aquifers. The age distribution of the steady-state model using MODPATH estimates the youngest 7 percent of the water to have a mean age of 16 years. In comparison, interpretations of age tracer and stable isotope data indicate water samples from the study PSW are a mixture of 7 to 14 percent water with a mean age of 14 years or less mixed with 86 to 93 percent old, upper confined aquifer water.

Long-term projections for nitrate- $\mathrm{N}$ concentrations were examined to explore the effects of denitrification on future nitrate-N concentrations. Projected nitrate-N concentrations at the study PSW were calculated by applying estimated concentrations of nitrate- $\mathrm{N}$ to particles from forward-tracking MODPATH results of the steady-state model. Estimated nitrate-N concentrations assume a constant proportion of about 45 percent urban land, 39 percent agricultural land, 11 percent forested land, and 4 percent rangeland. The calculated concentration of nitrate-N of $0.19 \mathrm{mg} / \mathrm{L}$ for 2003 of the forward projection is similar to measured values of nitrate- $\mathrm{N}$ at the study PSW, which range from 0.17 to $0.20 \mathrm{mg} / \mathrm{L}$. The projections indicate that nitrate- $\mathrm{N}$ concentrations reached values of about $0.19 \mathrm{mg} / \mathrm{L}$ by 2000 and will remain near this value for the next 100 years. This result is controlled by the denitrification rate. The peak value of decayed nitrate-N appears to lag behind the input concentration in recharge by approximately 30 years. For comparison, projection calculations assuming that denitrification does not occur in the upper confining unit and upper confined aquifer (decay rate equal to zero) indicated concen- trations of nitrate- $\mathrm{N}$ in the study PSW of $6.4 \mathrm{mg} / \mathrm{L}$ in 2003 and $12.3 \mathrm{mg} / \mathrm{L}$ after 100 years. The non-decayed concentration of nitrate-N does not appear to reach a peak value by 2110 , but continues to rise. This indicates a lag time of over 100 years behind the input concentration in recharge.

Simulation results are consistent with independent geochemical and hydrologic data indicating that wells screened through multiple aquifers allow downward flow through their well bores, thus providing a short circuit pathway from the unconfined aquifer through the upper confining unit to the upper confined aquifer. Consequently, leakage of young water through well bores is a major factor influencing the vulnerability of PSW to contamination in this multiaquifer system.

\section{References Cited}

Busenburg, E. and Plummer, L.N., 1992, Use of chlorofluorocarbons $(\mathrm{CCl} 3 \mathrm{~F}$ and $\mathrm{CCl} 2 \mathrm{~F} 2)$ as hydrologic tracers and age-dating tools: The alluvium and terrace system of Central Oklahoma: Water Resources Research, v. 28, no. 9, p. 2257-2283.

Cook, P.G., and Böhlke, J.K., 2000, Determining timescales for groundwater flow and solute transport, in Cook, P.G., and Herczeg, A. eds., Environmental tracers in subsurface hydrology: Kluwer Academic Publishers, Boston, p. 1-30.

Dennehy, K.F., 2000, High Plains Regional ground-water study: U.S. Geological Survey Fact Sheet FS-091-00, 6 p.

Dugan, J.T., and Zelt, R.B., 2000, Simulation and analysis of soil-water conditions in the Great Plains and adjacent areas, Central United States, 1951-80: U.S. Geological Survey Water-Supply Paper 2427, 81 p.

Eberts, S.M., Erwin, M.L., and Hamilton, P.A., 2005, Assessing the vulnerability of public-supply wells to contamination from urban, agricultural, and natural sources: U.S. Geological Survey Fact Sheet 2005-3022, 4 p.

Fetter, C.W., 1994, Applied Hydrogeology, (3d ed.): New York, MacMillan College Publishing Co., Inc., 691 p.

Freeze, R.A., and Cherry, J.A., 1979, Groundwater: Englewood Cliffs, New Jersey, Prentice-Hall, 604 p.

Goode, D.J., 1996, Direct simulation of groundwater age: Water Resources Research, v. 32, no. 2, p. 289-296.

Gutentag, E.D., Heimes, F.J., Krothe, N.C., Luckey, R.R., and Weeks, J.B., 1984, Geohydrology of the High Plains aquifer in parts of Colorado, Kansas, Nebraska, New Mexico, Oklahoma, South Dakota, Texas, and Wyoming: U.S. Geological Survey Professional Paper 1400-B, 63 p. 
Halford, K.J. and Hanson, R.T., 2002, User Guide for the Drawdown-Limited, Multi-Node Well (MNW) Package for the U.S. Geological Survey's Modular Three-Dimensional Finite-Difference Ground-Water Flow Model, Versions MODFLOW-96 and MODFLOW-2000: U.S. Geological Survey Open-File Report 02-293, p. 33

Hanson, R.T., Li, Zhen, and Faunt, C.C., 2004, Documentation of the Santa Clara Valley Regional Ground-Water/SurfaceWater Flow Model, Santa Clara County, California: U.S. Geological Survey Scientific Investigations Report 20045231, $75 \mathrm{p}$.

Harbaugh, A.W., Banta, E.R., Hill, M.C., and McDonald, M.G., 2000, MODFLOW-2000, the U.S. Geological Survey modular ground-water model - User guide to modularization concepts and the ground-water flow process: U.S. Geological Survey Open-File Report 00-92, 121 p.

High Plains Climate Center, 2003, National Weather Service Surface Observations and Automated Weather Data Network Data: available on the World Wide Web at http://www. hprcc.unl.edu/data.htm, accessed March 11, 2003.

Hill, M.C., Banta, E.R., Harbaugh, A.W., and Anderman, E.R., 2000, MODFLOW-2000, The U.S. Geological Survey modular ground-water model-User guide to the observation, sensitivity, and parameter-estimation processes and three post-processing programs: U.S. Geological Survey Open-File Report 00-184, 209 p.

Hsieh, P.A., and Winston, R.B., 2002, User's guide to model viewer, a program for three-dimensional visualization of ground-water model results: U.S. Geological Survey OpenFile Report 02-106, 18 p.

Jess, J.M., 1970, Use of ground-water for irrigation, Seward County, Nebraska: Nebraska Water Survey Paper 25, 24 p.

Johnson, C.R., and Keech, C.F., 1959, Geology and groundwater resources of the Big Blue River Basin above Crete, Nebraska: U.S. Geological Survey Water-Supply Paper 1474, 94 p., 2 pl.

Keech, C.F. Dreeszen, V.H., and Emery, P.A., 1967, Availability of ground water in York County, Nebraska: U.S. Geological Survey Water-Supply Paper 1839-F, 17 p.

Konikow, L.F., and Hornberger, G.Z., 2006, Use of the Multi-Node Well (MNW) Package when simulating solute transport with the MODFLOW Ground-Water Transport Process: U.S. Geological Survey Techniques and Methods 6-A15, 34 p.

Konikow, L.F., Goode, D.J., and Hornberger, G.Z., 1996, A three-dimensional Method-of-Characteristics Solute-Transport Model (MOC3D): U.S. Geological Survey Water-Resources Investigations Report, 96-4267, 87 p.
Landon, M.K., Clark, B.R., McMahon, P.B., McGuire, V.L., and Turco, M.J., in press, Hydrogeology, chemical characteristics, and transport processes in the zone of contribution of a public-supply well in York, Nebraska: U.S. Geological Survey Scientific Investigations Report 2008-5050.

Landon, M.K., and Johnson, M.R., 2002, Preliminary data used in estimating ground-water recharge, pumpage, and evapotranspiration in part of the Republican River Basin, Nebraska, Kansas, and Colorado: U.S. Geological Survey Open-File Report 2002-241, 42 p.

Landon, M.K., and Turco, M.J., 2007, Section 8, Hydrogeologic setting and ground-water flow simulation of the eastern High Plains regiona study area, Nebraska, in Paschke, S.S., ed., 2006, Hydrogeologic settings and ground-water flow simulations for regional studies of the transport of anthropogenic and natural contaminants to public-supply wells_-Studies begun in 2001: U.S. Geological Survey Professional Paper 1737-A., 28 p.

Leake, S.A. and Lilly, 1997, Documentation of a Computer Program (FHB1) for Assignment of Transient SpecifiedFlow and Specified-Head Boundaries in Applications of the Modular Finite-Difference Ground-Water Flow Model (MODFLOW): U.S. Geological Survey Open-File Report 97-571, 50 p.

Luckey, R.R., Gutentag, E.D., Heimes, F.J., and Weeks, J.B., 1986, Digital simulation of ground-water flow in the High Plains aquifer in parts of Colorado, Kansas, Nebraska, New Mexico, Oklahoma, South Dakota, Texas, and Wyoming: U.S. Geological Survey Professional Paper 1400-D, 63 p.

McMahon, P.B., Böhlke, J.K., and Bruce, B.W., 1999, Denitrification in marine shales in northeastern Colorado, USA: Water Resources Research, v. 35, no. 5, p. 1629-1642.

McMahon, P.B., Böhlke, J.K., Kauffman, L.J., Kipp, K.L., Landon, M.K., Crandall, C.A., Burow, K.R., and Brown, C.J., 2008, Source and transport controls on the movement of nitrate to public supply wells in selected principal aquifers of the United States: Water Resources Research, v. 44, W04401, doi:10.1029/2007WR006252.

McMahon, P.B., Dennehy, K.F., Bruce, B.W., Böhlke , J.K., Michel, R.L, Gurdak, J.J., and Hurlbut, D. B., 2006, Storage and transit time of chemicals in the thick unsaturated zones under rangeland and irrigated cropland, High Plains, USA: Water Resources Research, v. 42, W03413, doi:10.1029/2005WR004417.

Morrissey, D.J., 1989, Estimation of the recharge area contributing water to a pumped well in a glacial-drift, river-valley aquifer: U.S Geological Survey Water-Supply Paper 2338, $41 \mathrm{p}$. 
National Research Council, 1993, Ground water vulnerability assessment, contamination potential under conditions of uncertainty: Washington, D.C., National Academy Press, $210 \mathrm{p}$.

Nebraska Department of Natural Resources, 2003, GroundWater Well Registry: available on the World Wide Web at http://www.dnr.ne.gov/docs/groundwat.html, accessed 2003.

Pollock, D.W., 1994, User's Guide for MODPATH/MOD-

PATH-PLOT, Version 3: A particle tracking post-processing package for MODFLOW, the U.S. Geological Survey

finite-difference ground-water flow model: U.S. Geological Survey Open-File Report 94-464, 6 ch.

Reilly, T.E., and Pollock, D.W., 1993, Factors affecting areas contributing recharge to wells in shallow aquifers: U.S. Geological Survey Water-Supply Paper 2412, 21 p.

Steele, E.K., 1973, Use of ground-water for irrigation in Seward County, Nebraska: U.S. Geological Survey OpenFile Report 73-08, 28 p.

U.S. Geological Survey, 2005, The Reston Chlorofluorocarbon laboratory: accessed February 10, 2006 at URL http://water. usgs.gov/lab/

U.S. Geological Survey, 2007, USGS NAWQA Transport of Anthropogenic and Natural Contaminants to Supply Wells: accessed February 10, 2006 at URL http://oh.water.usgs. gov/tanc/NAWQATANCLocations.htm 



\section{Appendixes 1-2}




\section{Appendix 1. Computation of MODPATH Particle Traveltimes Through Well Bores}

Because MODPATH was not designed to accommodate particle tracking through well bores, the particle-tracking results for this study were manipulated to account for movement of water through well bores. The purpose of this appendix is to describe the approach used to account for this movement. A hypothetical example will be used to help illustrate the approach. The example is intended only as an illustration (fig. 1-1) and does not reflect layer assignments or properties associated with the local-scale model described in the main text of this report.

Particle tracking involves analyzing the path a particle of water takes as it moves through the ground-water system and the time it takes for the particle to travel that path. The approach used in this report was to start particles at all areas where water enters the ground-water system. These particles were tracked until they reached a discharge point. Particles were evenly spaced on cell boundaries where water entered the model domain, thus each particle represented the volume of water entering over some area on the model boundary. For example, if four particles were started on a model cell face, each has an associated flow equal to the flow across the cell face divided by four. The path followed by a particle through the aquifer was assumed to represent a flow tube that would be formed by the water entering over the area of the boundary represented by that particle.

Multi-node wells (MNWs) add complexity to the particle tracking because water enters these wells and is potentially mixed with other water in the well bore and discharged back into the aquifer. To understand the movement into, out of, and within the MNW, algorithms were developed for routing and mixing of water based on the MODFLOW cell-by-cell budget file. Particles also were started in model cells where MNWs discharge water back into the aquifer. This MNW routing and mixing information then was used to link particles that are associated with water entering a MNW with those particles associated with water leaving a MNW.

In the example problem, particles p6, p7, p8, and p9 were started at the leaking part (layers 7 and 8) of MNW1. Other particles originated at the recharge boundary (origin of particle p5 not shown). The particles were tracked until they reached a discharge point (a MNW or a model boundary). In this example, all particles terminated at MNW1 or MNW2 with the exception of particle p9, which terminated at an unknown place outside of the example area. The MODPATH program calculated a traveltime for each particle.

To account for mixing in and leakage through the well bores using MODPATH, the algorithm in the GWT process (Konikow and Hornberger, 2006) was used to calculate where water leaving the leaking part of MNW1 (into example layers 7 and 8) would have entered (from example layers 3, 4, 5, and 10) and mixed in MNW1. In the algorithm complete mixing of water within the well associated with each model layer was assumed. The direction of the movement of water in the well between model layers was governed by the mass balance of water. Table 1-1 shows (for the example problem) the amount of water moving (in MNW1) between each of the model layers and the relative composition of the mix of water in and between each of the model layers. Based on the composition of the water in and the flow out of cells where water is leaving the well, the final destination for water entering the well can be computed (table 1-1).

To calculate the traveltime of the entire flow path for each particle, the particles entering MNW1 (particles p1, p2, p3, p4, and $\mathrm{p} 5$ ) were linked to particles moving from the discharging part of MNW1 to MNW2 (particles p6, p7, and p8). The linkage was based on the mixing algorithm for MNW1. Table 1-2 shows the linkage for the example problem.

For a particle that terminates at MNW1, the water associated with the particle is transferred to the particles that are started in the discharging layers of MNW1. In the example, particle p2 enters in layer 4. From table 1-1, 50 percent of the water associated with particle $\mathrm{p} 2$ contributed to the withdrawal demand of MNW1, 40 percent goes to layer 7, and 10 percent goes to layer 8. In the example, all of the water associated with particle $\mathrm{p} 1$ and half of the water associated with particle $\mathrm{p} 2$ would satisfy the pumping of MNW1. Half of the water from particle $\mathrm{p} 2$ and the water associated with particles $\mathrm{p} 3, \mathrm{p} 4$, and $\mathrm{p} 5$ provided the source of water that leaks back into the aquifer to layers 7 and 8 and is associated with particles p6, $\mathrm{p} 7, \mathrm{p} 8$, and $\mathrm{p} 9$. The traveltimes were summed for the various parts of a flow path to calculate a composite traveltime. In the example, the water associated with particle $\mathrm{p} 6$ has three parts to its composite traveltime:

- the traveltime of particle $\mathrm{p} 2+$ the travel time of particle p6

- the traveltime of particle $\mathrm{p} 3+$ the travel time of particle p6

- the traveltime of particle $\mathrm{p} 4+$ the travel time of particle p6

Similarly the composite traveltime for the water associated with particle $\mathrm{p} 7$ has three parts, and particles $\mathrm{p} 8$ and $\mathrm{p} 9$ have four parts because particle $\mathrm{p} 5$ also contributes.

The age distribution of water in a well can then be constructed based on traveltimes of particles (including the composite travels times described above) that terminate at that well. The particles which terminate at MNW2 are particles $\mathrm{p} 6, \mathrm{p} 7, \mathrm{p} 8$, and $\mathrm{p} 10$. The age distribution would be constructed from 11 values: 3 composite values from particles $\mathrm{p} 6$ and p7, 4 composite values from particle $\mathrm{p} 8$, and the value from particle p10. These values are highlighted (bold type) in table 1-2. 


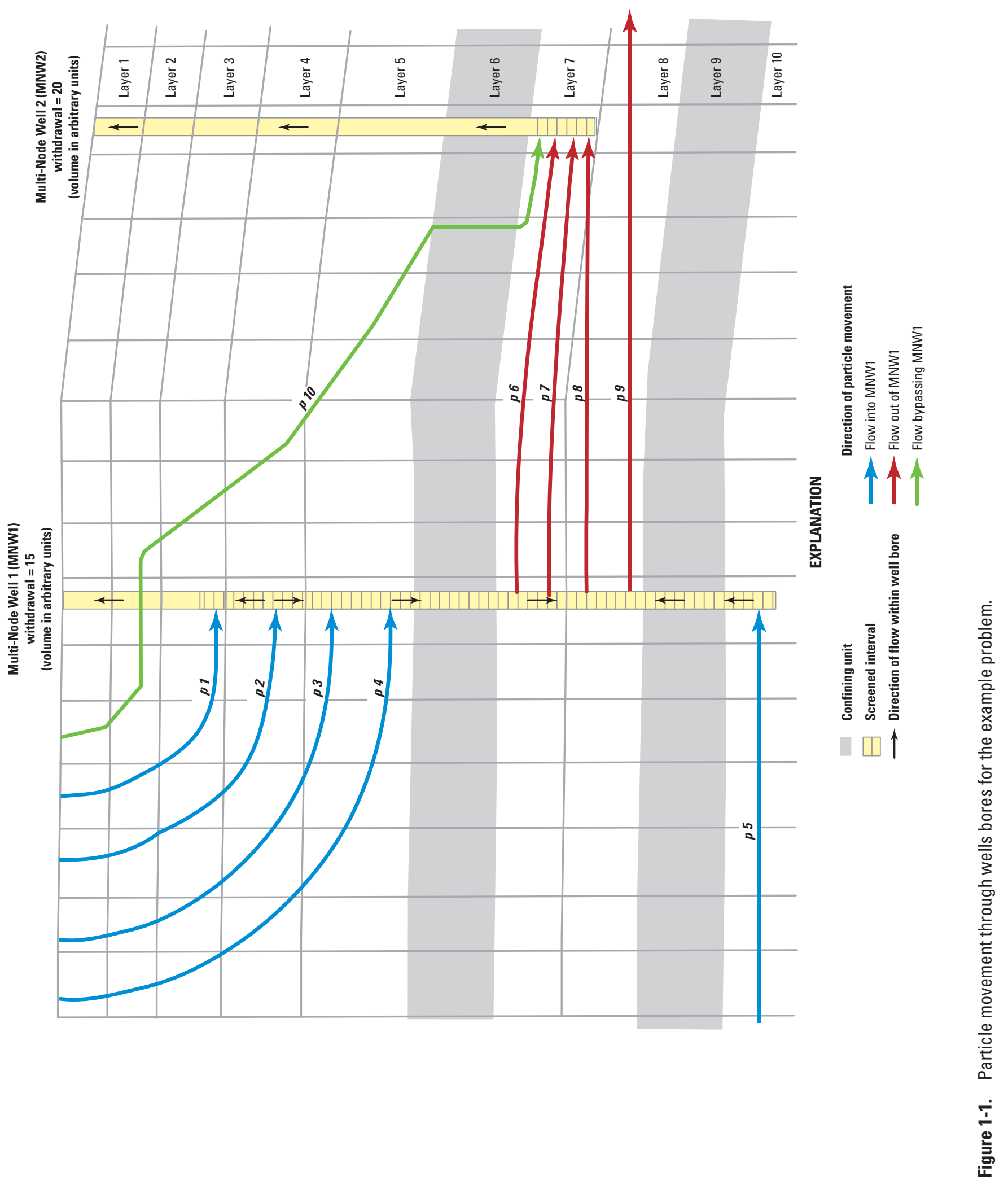




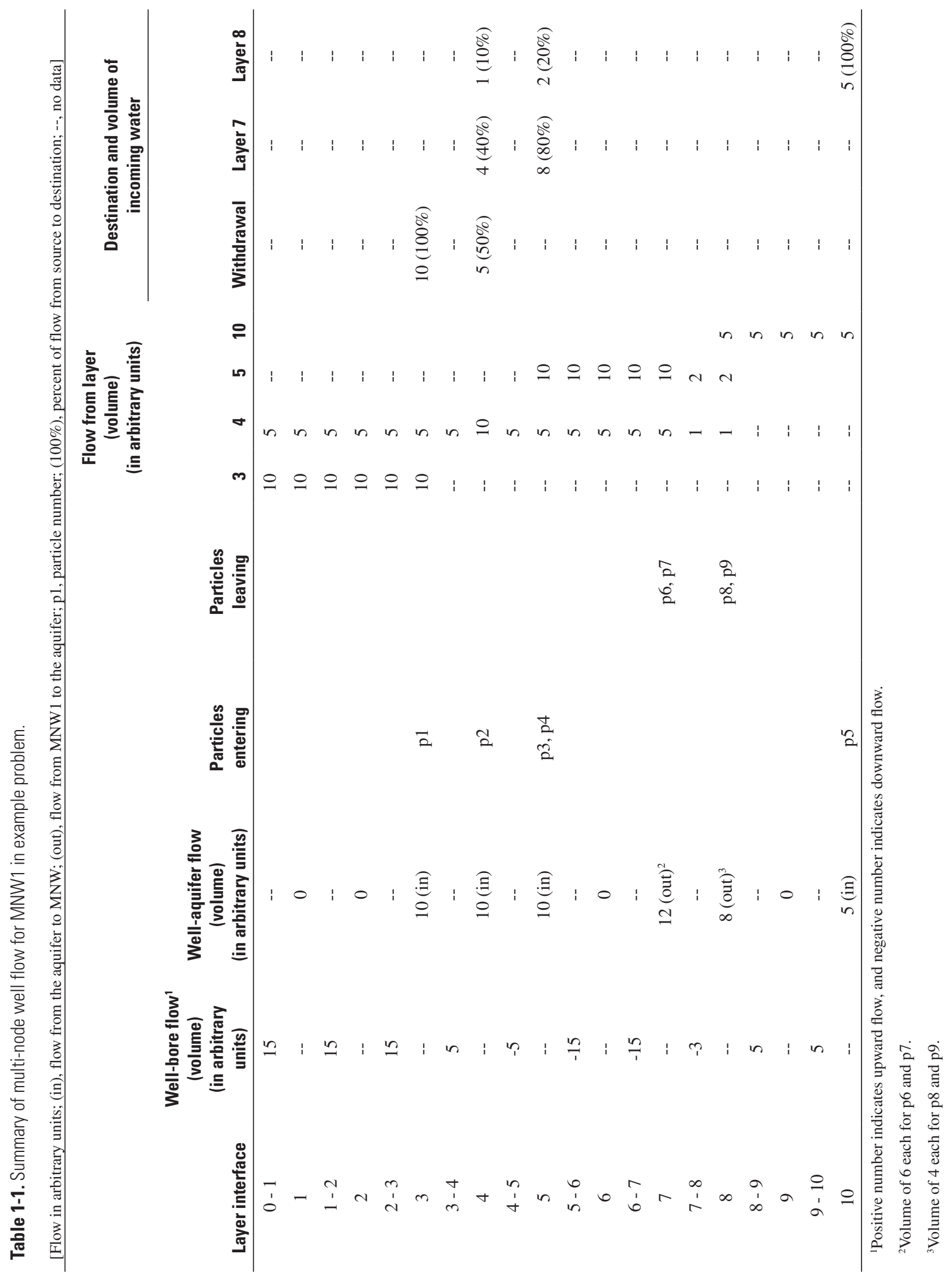


Table 1-2. Traveltime of particles that begin or end in an example multi-node well (MNW1) particle-tracking problem.

[Flow and time in arbitrary units; TT, traveltime; Bold lines are those that contribute to Well 2.]

\begin{tabular}{|c|c|c|c|c|c|}
\hline & Particles $^{1}$ & $\begin{array}{c}\text { Flow } \\
\text { (volume) }\end{array}$ & $\begin{array}{l}\text { Starting } \\
\text { layer of } \\
\text { particle } \\
\text { in MNW1 }\end{array}$ & $\begin{array}{l}\text { Ending } \\
\text { layer of } \\
\text { particle } \\
\text { in MNW1 }\end{array}$ & Travel Time \\
\hline $\mathrm{p} 1$ & & 10 & & 3 & 5 \\
\hline $\mathrm{p} 2$ & & 10 & & 4 & 8 \\
\hline p3 & & 6 & & 5 & 12 \\
\hline $\mathrm{p} 4$ & & 4 & & 5 & 20 \\
\hline p5 & & 5 & & 10 & 80 \\
\hline \multirow[t]{4}{*}{ p6 } & & 6 & 7 & & 4 \\
\hline & $p 2-p 6$ & 2 & 7 & & $T T p 2+\operatorname{TTp} 6=12$ \\
\hline & p3-p6 & 2.4 & 7 & & $T T p 3+T T p 6=16$ \\
\hline & $p 4-p 6$ & 1.6 & 7 & & $T T p 4+T T p 6=24$ \\
\hline \multirow[t]{4}{*}{ p7 } & & 6 & 7 & & 6 \\
\hline & $p 2-p 7$ & 2 & 7 & & $T T p 2+T T p 7=14$ \\
\hline & $p 3-p 7$ & 2.4 & 7 & & $T T p 3+T T p 7=18$ \\
\hline & $p 4-p 7$ & 1.6 & 7 & & $T T p 4+T T p 7=26$ \\
\hline \multirow[t]{5}{*}{$\mathrm{p} 8$} & & 4 & 8 & & 10 \\
\hline & $p 2-p 8$ & 0.5 & 8 & & $T T p 2+T T p 8=18$ \\
\hline & p3-p8 & 0.6 & 8 & & $T T p 3+T T p 8=22$ \\
\hline & p4-p8 & 0.4 & 8 & & $T T p 4+T T p 8=30$ \\
\hline & $p 5-p 8$ & 2.5 & 8 & & $T T p 5+T T p 8=90$ \\
\hline \multirow[t]{5}{*}{ p9 } & & 4 & 8 & & 50 \\
\hline & $p 2-p 9$ & 0.5 & 8 & & $T T p 2+T T p 9=58$ \\
\hline & $p 3-p 9$ & 0.6 & 8 & & $T T p 3+T T p 9=62$ \\
\hline & $p 4-p 9$ & 0.4 & 8 & & $T T p 3+T T p 9=70$ \\
\hline & $p 5-p 9$ & 2.5 & 8 & & $T T p 5+T T p 9=130$ \\
\hline p10 & & 10 & 7 & & 55 \\
\hline
\end{tabular}

${ }^{1}$ The particles that are started in MNW1 represent water that came in to the well associated with other particles. The composite traveltime is shown in italics for each of these particles at MNW2. See diagram in figure 1-1. 


\section{Appendix 2. Digital Three-Dimensional Animations of CFC-11 Transport Simulations}

Animations illustrating simulation of chlorofluorocarbon-11 (CFC-11) concentrations in one calibrated and two alternative ground-water flow and transport models are included in AVI format on the enclosed compact disk (CD). A README file also explains how to install and view the AVI on a personal computer. A PDF file format of the report is available on the $\mathrm{CD}$.

The animations contained on the $\mathrm{CD}$ were created using ModelViewer version 1.1.1 for MS-WINDOWS (Hsieh and Winston, 2002). These data for the animations were read from the *.cnb output files from MODFLOW-GWT.

Animations included on the CD consist of simulations of CFC-11 concentrations from September 1, 1944, to August 31, 2004, and steady-state conditions representing 1997-2001:

CFC_sg_wAbnd.avi - Simulated CFC-11 in the upper confined aquifer of the calibrated model (with abandoned wells).

CFC_sg_NoAbnd.avi - Simulated CFC-11 in the upper confined aquifer of the First alternative model (without abandoned well model).

CFC_sg_SS.avi - Simulated CFC-11 in the upper confined aquifer of the Third alternative model (steady-state model).

Compare.avi - Comparison of the calibrated model with First and Third alternative models (without abandoned well and steady-state models).

CompareXS.avi - Comparison of the calibrated model with First and Third alternative models (without abandoned well and steady-state models) in cross-sectional view. 
Publishing support provided by:

Lafayette and Rolla Publishing Service Centers

For more information concerning the research described in the report:

U.S. Geological Survey

Arkansas Water Science Center

401 Hardin Road

Little Rock, AR 72211-3528

(501) 228-3600

http://ar.water.usgs.gov 
